\title{
European Red List of Lycopods and Ferns
}

\section{Garcia Criado, Mariana}

IUCN

2017-12-01

Garcia Criado , M , Väre , HU , Nieto , A, Bento Elias , R, Dyer , R, Ivanenko , Y , Ivanova , D , Lansdown , R, Molina , J A , Rouhan, G , Rumsey , F , Troia , A , Vrba , J \&

Christenhusz , M J M 2017 , European Red List of Lycopods and Ferns . IUCN , Brussels . https://doi.org/10.2305/IU

http://hdl.handle.net/10138/232419

https://doi.org/10.2305/IUCN.CH.2017.ERL.1.en

publishedVersion

Downloaded from Helda, University of Helsinki institutional repository.

This is an electronic reprint of the original article.

This reprint may differ from the original in pagination and typographic detail.

Please cite the original version. 


\section{European Red List of Lycopods and Ferns}

Mariana García Criado, Henry Väre, Ana Nieto, Rui Bento Elias, Robert Dyer, Yury Ivanenko, Daniella Ivanova, Richard Lansdown, José Antonio Molina, Germinal Rouhan, Fred Rumsey, Angelo Troia, Jan Vrba and Maarten J. M. Christenhusz 



\section{European Red List of Lycopods and Ferns}

Mariana García Criado, Henry Väre, Ana Nieto, Rui Bento Elias, Robert Dyer, Yury Ivanenko, Daniella Ivanova, Richard Lansdown, José Antonio Molina, Germinal Rouhan, Fred Rumsey,

Angelo Troia, Jan Vrba and Maarten J. M. Christenhusz 
The designation of geographical entities in this book, and the presentation of the material, do not imply the expression of any opinion whatsoever on the part of IUCN concerning the legal status of any country, territory, or area, or of its authorities, or concerning the delimitation of its frontiers or boundaries.

The views expressed in this publication do not necessarily reflect those of IUCN.

This publication has been prepared by IUCN (International Union for Conservation of Nature) as a deliverable of the LIFE European Red Lists project (LIFE14 PRE/BE/000001).

Project Title: Establishing a European Red List of Bryophytes, Pteridophytes, Saproxylic Beetles, Terrestrial Molluscs and Vascular Plants (LIFE European Red Lists; LIFE14 PRE/BE/000001).

Project duration: May 2015 to December 2018.

Project's total costs: 1,166,667 EUR.

Contribution of the LIFE Programme: 700,000 EUR.

The LIFE Programme (http://ec.europa.eu/environment/life/index.htm) is the EU's financial instrument supporting environmental, nature conservation and climate action projects throughout the EU. The general objective of LIFE is to contribute to the implementation, updating and development of EU environmental, nature conservation and climate policy and legislation by cofinancing projects with European added value.

Published by:

IUCN, Brussels, Belgium

Copyright:

(C) 2017 IUCN. All rights reserved. Licensed to the European Union under conditions.

Reproduction of this publication for educational or other non-commercial purposes is authorised without prior written permission from the copyright holder provided the source is fully acknowledged.

Reproduction of this publication for resale or other commercial purposes is prohibited without prior written permission of the copyright holder.

Citation:

García Criado, M., Väre, H., Nieto, A., Bento Elias, R., Dyer, R., Ivanenko, Y., Ivanova, D., Lansdown, R., Molina, J.A., Rouhan, G., Rumsey, F., Troia, A., Vrba, J. and Christenhusz, M.J.M. 2017. European Red List of Lycopods and Ferns. Brussels, Belgium: IUCN. iv + 59pp.

ISBN:

$978-2-8317-1855-2$

DOI: http://dx.doi.org/10.2305/IUCN.CH.2017.ERL.1.en

Design and layout: Imre Sebestyén jr. / UNITgraphics.com

Picture credits on cover page:

Double Spleenwort (Asplenium anceps) is endemic to Madeira and the Canary Islands, and it is extinct in the Azores. It is mainly threatened by habitat destruction. It has been assessed as Endangered. () Fred Rumsey.

All photographs used in this publication remain the property of the original copyright holder (see individual captions for details).

Photographs should not be reproduced or used in other contexts without written permission from the copyright holder.

Printed by: media process, Belgium

Available from:

IUCN (International Union for Conservation of Nature)

64 Boulevard Louis Schmidt 1040 Brussels, Belgium

brussels@iucn.org

www.iucn.org/resources/publications 


\section{Table of contents}

Acknowledgements

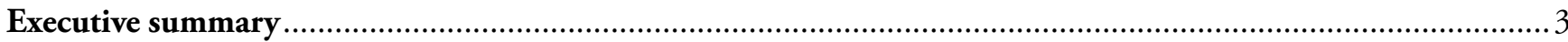

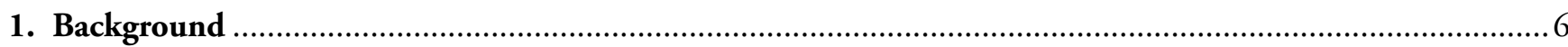

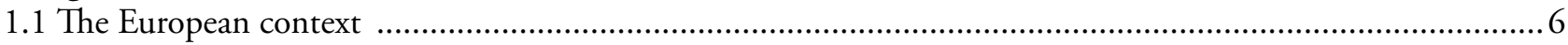

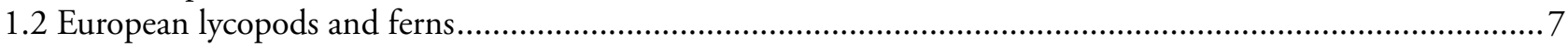

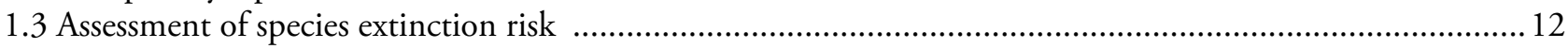

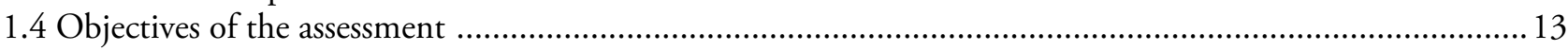

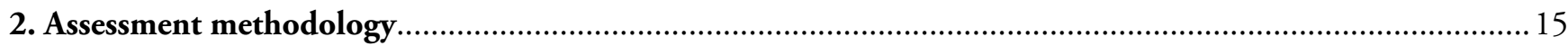

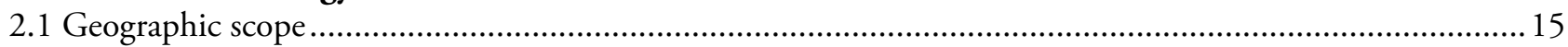

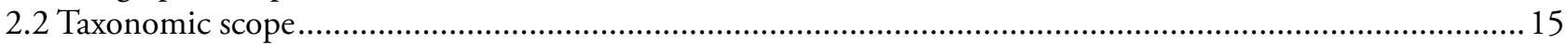

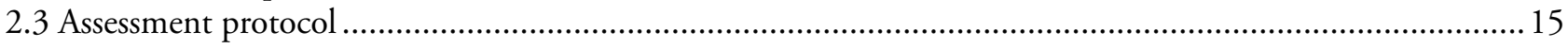

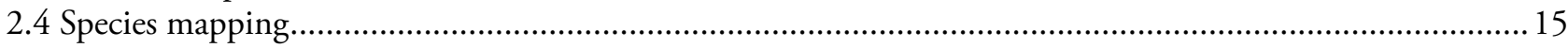

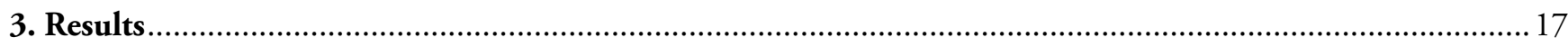

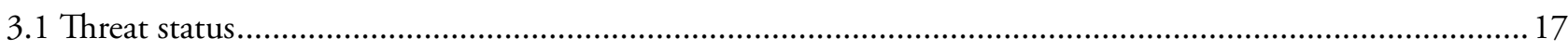

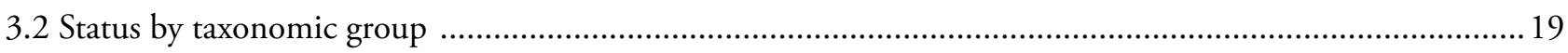

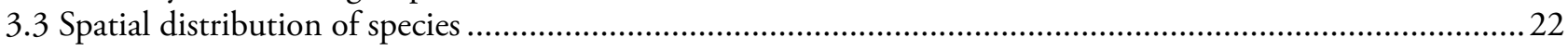

3.4 Major threats to lycopod and fern species in Europe............................................................................26

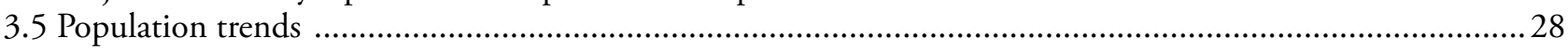

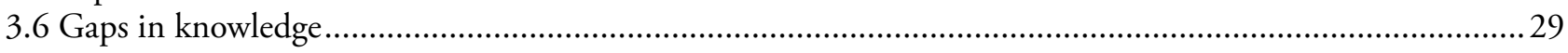

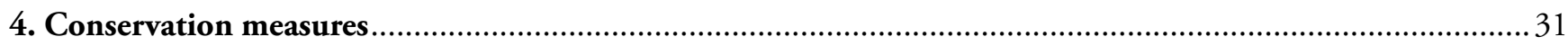

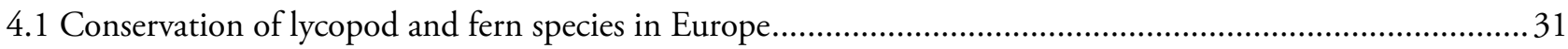

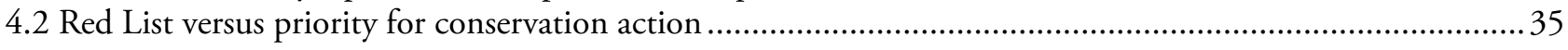

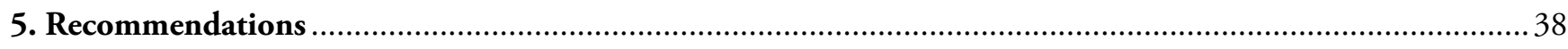

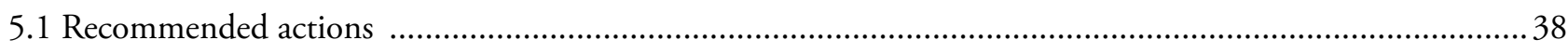

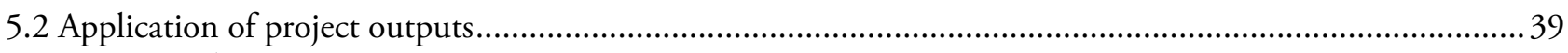

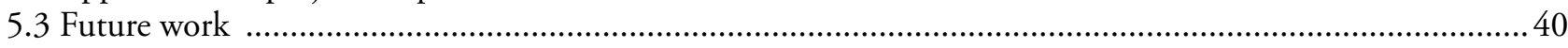

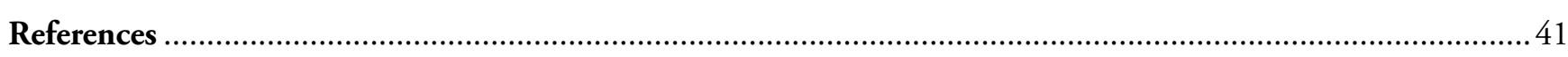

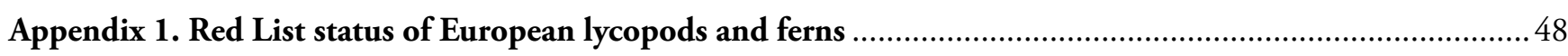

Appendix 2. Example of species summary and distribution map …............................................................53 


\section{Foreword}

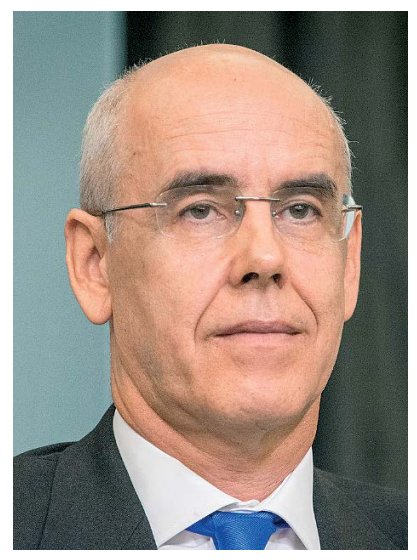

Europe has a rich natural heritage, with habitats ranging from dry Mediterranean maquis in the south to the Arctic tundra in the far north. However, Europe's landscape has been shaped by centuries of diverse farming and forestry traditions. As a result, a large number of agricultural and semi-natural landscapes have emerged and significantly affected the continent's biodiversity.

Biodiversity loss as a result of human impacts is one of the major challenges that the EU currently faces, and this has considerably affected valuable ecosystem services. In order to halt the loss of biodiversity, the EU Biodiversity Strategy was adopted in 2011 and aims to protect, value and restore biodiversity and the services it provides Europe's natural capital. This is important not only to protect nature for its own sake, but also for its essential contribution to human well-being and economic prosperity, and also to avert catastrophic changes caused by biodiversity loss. After all, everyone will understand that we cannot act sustainably if we keep destroying nature.

In recent years, awareness has risen surrounding the crucial role of plants in providing ecosystem services and on their decline - they are one of the essential foundations of healthy ecosystems that we depend on. However, significant gaps in knowledge still remain. In this context, the European Red List of Lycopods and Ferns provides the first ever comprehensive assessment of the extinction risk of all native lycopod and fern species to Europe. With 194 species assessed, this assessment highlights that $19.9 \%$ of lycopod and fern species are threatened with extinction in Europe. This is mainly due to urban and infrastructure development, human intrusions and disturbance, pollution, and water use and management.

Lycopods and ferns present a high level of endemism, with 53 species $(27.3 \%)$ being endemic to Europe. As these species are found nowhere else in the world, Europe has a responsibility to conserve them. The assessment also indicates that they are the most threatened group of plant species assessed so far by the IUCN European Red List. By comparison, $2 \%$ of medicinal plants, $8 \%$ of aquatic plants and $16 \%$ of crop-wild relatives are threatened.

Thus, immediate measures must be taken in order to improve the status of European lycopods and ferns and tackle the degradation of their habitats. A multidisciplinary approach needs to be established; while species and protected area management is key, the proper implementation of the existing European legislation will be crucial in providing protection to the species, including the EU Birds and Habitats Directive.

I hope that this new IUCN European Red List will help place plants higher on the conservation agenda as well as inform the wider debate and contribute to the discussion on priorities within the conservation community. A network of lycopod and fern experts is already in place, therefore more investment in scientific research, and increasing awareness and communications will help towards the delivery of real results and positive impacts for these species.
Humberto Delgado Rosa

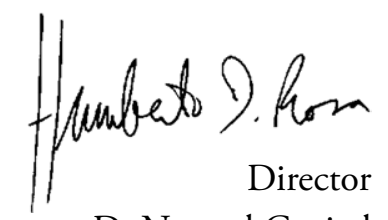

Directorate D: Natural Capital European Commission 


\section{Acknowledgements}

All of IUCN's Red Listing processes rely on the willingness of scientists to contribute and pool their collective knowledge to make the most reliable estimates of the status of a species. Without their enthusiastic commitment to species conservation, this kind of regional overview would not be possible.

Coordination of the European Red List of Lycopods and Ferns was carried out by Mariana García Criado (IUCN European Regional Office, Global Species Programme) with support from Ana Nieto. It greatly benefitted from the support of the Red List Unit, in particular from Caroline Pollock and David Allen. The data for the species assessments was compiled by Henry Väre (Dryopteris) and Maarten Christenhusz (all other species).

Craig Hilton-Taylor and Jean-Christophe Vié provided guidance, encouragement and advice throughout the project. Jan Vrba (Ministry of Environment of the Czech Republic) and Jemma Window (IUCN) provided highquality support on Geographic Information Systems. Hereby, we record our gratitude to them.

Anna Rosenberg and Corinna Karlsen provided substantial assistance with the financial management of the project. A word of thanks goes to Bianca Vergnaud and Marta Cálix for their support on communicationrelated matters. We are also grateful to the photographers, who provided photos for the species assessments and the photos in this publication.

The Finnish Museum of Natural History (LUOMUS) is acknowledged for kindly providing the distribution information published in Atlas Florae Europaeae (Jalas and Suominen 1972) and the IUCN SSC Freshwater Plant Specialist Group for their contribution.

We thank Malin Rivers and Barbara Goettsch for peerreviewing this publication and Hanno Schäfer for his input in the review process of the assessments and this publication. Finally, special thanks go to Thomas Abeli, Mattia Azzella, Teresa Napolitano, François Pinet and Brigitte Zimmer.

The European Red List of Lycopods and Ferns, and consequently this publication, are deliverables of a LIFE project co-funded by the European Commission and other donors (LIFE14 PRE/BE/000001 - LIFE European Red Lists). In particular, we would like to thank Frank Vassen (European Commission, DG Environment) and the LIFE monitors for their support throughout the project, allowing for a smooth implementation. 


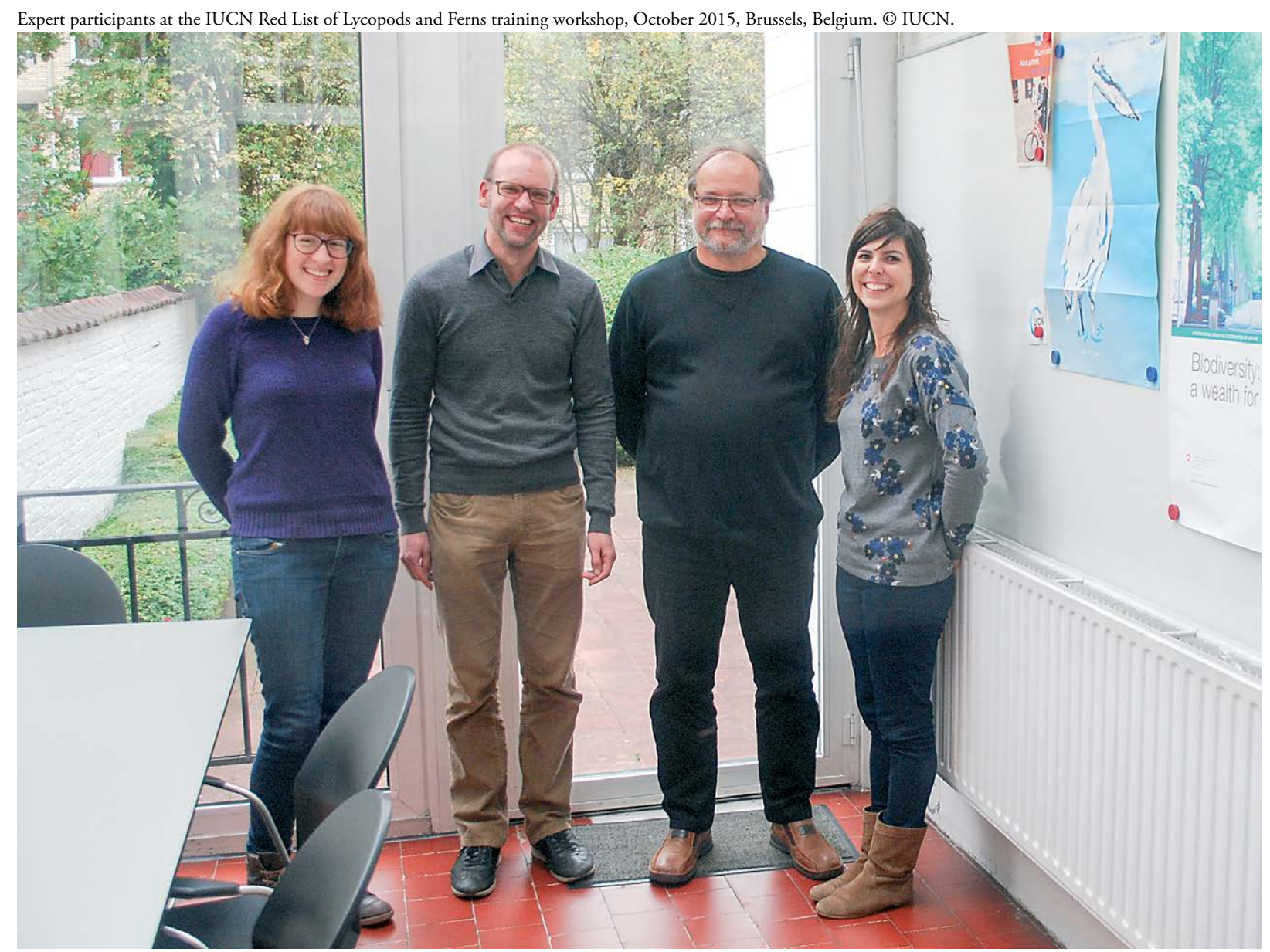

Expert participants at the IUCN Red List of Lycopods and Ferns assessment workshop, June 2016, Brussels, Belgium. (C) IUCN.

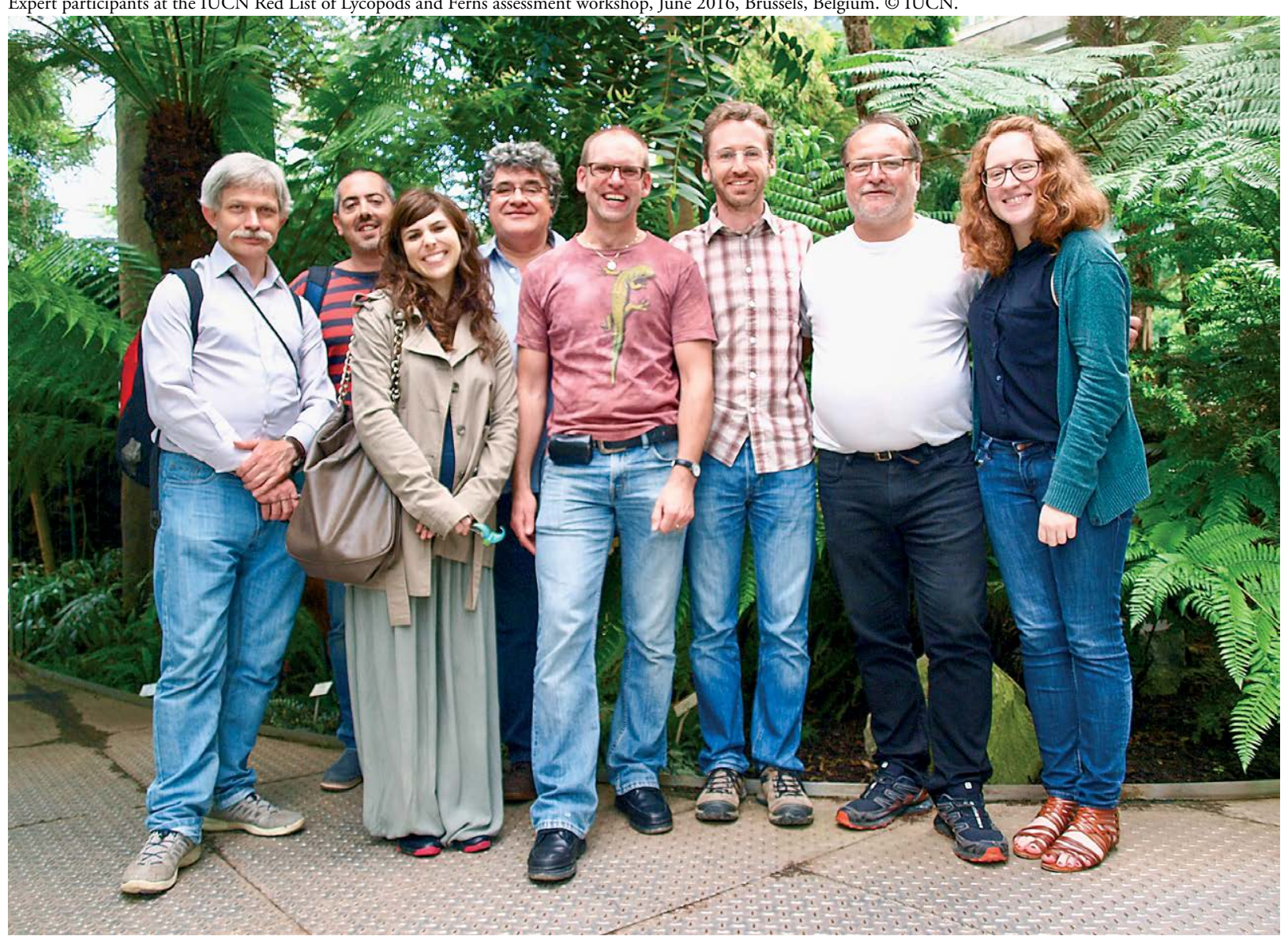




\section{Executive summary}

\section{Aim}

The European Red List is a review of the conservation status of European species according to IUCN's regional Red Listing guidelines. It identifies those species that are threatened with extinction at the regional level, so that appropriate conservation action can be taken to improve their status. This Red List publication summarises results for all known native European lycopod and fern species.

\section{Scope}

All lycopod and fern species native to or naturalised in Europe before AD 1500 (a total of 194 species), have been assessed in this Red List. The geographical scope is continent-wide, extending from Iceland in the west to the Urals in the east, and from Franz Josef Land in the north to the Canary Islands in the south. The Caucasus region is not included. Red List assessments were made at two regional levels: for geographical Europe, and for the 28 Member States of the European Union.

\section{Status assessment}

The status of all species was assessed using the IUCN Red List Categories and Criteria (IUCN 2012a), which are the world's most widely accepted system for measuring extinction risk. All assessments followed the Guidelines for Application of IUCN Red List Criteria at Regional and National Levels (IUCN 2012b).

These assessments were compiled based on the data and knowledge from two leading experts on lycopods and ferns. The assessments were then completed and reviewed by a network of European specialists on ferns and lycopods at a workshop held in Brussels, Belgium, and through email correspondence with relevant experts. More than 20 experts participated in the assessment and review process. Assessments are available on the European Red List website and data portal: http:// ec.europa.eu/environment/nature/conservation/species/redlist and http://www.iucnredlist.org/initiatives/europe.

\section{Results}

Overall, 19.9\% of European lycopod and fern species assessed in this study are considered threatened in Europe and one species is classified as Regionally Extinct (RE). A further $13.4 \%$ (26 species) are considered Near Threatened and $63.4 \%$ (123 species) are assessed as Least Concern. However, for seven species (3.6\%), there was insufficient scientific information available to be able to evaluate their risk of extinction and thus they were classified as Data Deficient (DD). When more data become available, some of these species might also prove to be threatened.

By comparison, of those other groups that were assessed comprehensively in Europe, 59\% of freshwater molluscs, $40 \%$ of freshwater fishes, $28.5 \%$ of grasshoppers, crickets and bush-crickets, $23 \%$ of amphibians, $20 \%$ of reptiles, $17 \%$ of mammals, $16 \%$ of dragonflies, $13 \%$ of birds, $9 \%$ of butterflies and bees, $8 \%$ of aquatic plants, $7.5 \%$ of marine fishes and $2 \%$ of medicinal plants are threatened (IUCN 2015, Hochkirch et al. 2016). Additional European Red Lists assessing a selection of species showed that $22 \%$ of terrestrial molluscs, $16 \%$ of crop wild relatives and $15 \%$ of saproxylic beetles are also threatened (IUCN 2015). No other groups have yet been assessed at the European level, but additional plant and invertebrate assessments are underway. This makes ferns and lycopods the most threatened group of plants assessed so far in Europe.

Looking at the population trends of European lycopods and ferns, $21.2 \%$ (41 species) have declining populations, $63.7 \%$ (123 species) are more or less stable and 2.6\% (five species) are increasing. The population trends for 24 species $(12.4 \%)$ remain unknown. 24 of the 53 species (45.3\%) that are endemic to Europe (i.e., they are found nowhere else in the world) are threatened (Critically Endangered, Endangered or Vulnerable), highlighting the responsibility that European countries have to protect the global populations of these species.

Overall, the European areas with the highest diversity of species are the Macaronesian islands and several mountainous areas in Europe such as the Alps, Pyrenees, Massif Central and the Carpathians. Hotspots of endemic species are mainly found in the Azores, Madeira and the Canary Islands. Furthermore, the greatest concentrations of threatened species are situated in Madeira, the Azores and the Swiss Alps. Finally, Data Deficient (DD) species are present in and around the Alps, Croatia, Crimea, Greece, Italy, France, the Canary Islands, Scandinavia and northern UK. 
The main threat to lycopods and ferns is urbanisation and infrastructure, which includes the building of tourist, recreational, residential, commercial and industrial areas and infrastructure and the construction of roads and railroads. Other important threats include human intrusions and disturbance, pollution, water use and management, deforestation, agricultural intensification, abandonment and other ecosystem modifications, invasive or problematic species, livestock grazing, climate change, collection, afforestation, wildfires, mining and quarrying, and geological events.

\section{Recommendations}

\section{Policy measures}

- Use the European Red List to inform revisions and guide the implementation of relevant European legislation and policy to improve the status of threatened species.

- Update the European Red List every decade to ensure that the data remains current and relevant.

- Ensure that existing Natura 2000 sites and other protected areas provide adequate protection to threatened lycopod and fern species.

- Establish new protected areas to enhance the status of threatened species so that each threatened and endemic European species is present in at least one protected area with an adequate adaptive management plan.

\section{Research and monitoring}

- Establish a monitoring programme in order to understand population sizes and trends of fern and lycopod species in Europe.

- Encourage scientific study on the biology of threatened species in order to better define the most important biotic and abiotic factors that may impact the status of these species.

- Specific research for species that are possibly extinct should be carried out. Likewise, more research is needed on the distribution, population trends and taxonomy of Data Deficient taxa in order to assess their risk of extinction in Europe.

- The effects of certain threats that are not yet fully understood (e.g., climate change) should be studied.

- Enhance and strengthen the expert network of lycopods and ferns in Europe in order to improve the knowledge of European species.

\section{Action on the ground}

- Develop and implement conservation strategies and management plans for threatened species, with a special attention to endemic species.

- Habitat restoration is needed, especially in aquatic habitats and wetlands that are highly affected by pollution, canalisation, drainage and changes in hydrological regime.

- Habitat protection is recommended in order to avoid further degradation, together with the provision of suitable areas for ferns and lycopods.

- Maintain traditional land management in areas where threatened species are dependent on this.

- Management and control of invasive alien species, especially in areas where these are abundant, such as the Macaronesian islands.

\section{Ex situ conservation}

- Undertake ex situ conservation of species of conservation concern in botanical gardens or by national pteridological societies.

- Ensure the conservation of threatened ferns and lycopods in spore and gene banks.

- Reintroduce threatened and Regionally Extinct species in the wild in suitable habitats when necessary and possible.

\section{Awareness raising}

- When renovation works or road expansions threaten populations growing on mortared or dry-stone walls, public awareness should be raised on the importance of leaving some specimens in place in order to avoid local extinctions. 
Hottentot Fern (Thelypteris pozoi) is a widespread species, although in Europe it is only found in the Macaronesian islands, Spain and France, where it is usually found near the sea. It has been assessed as Least Concern. (C) Fred Rumsey.

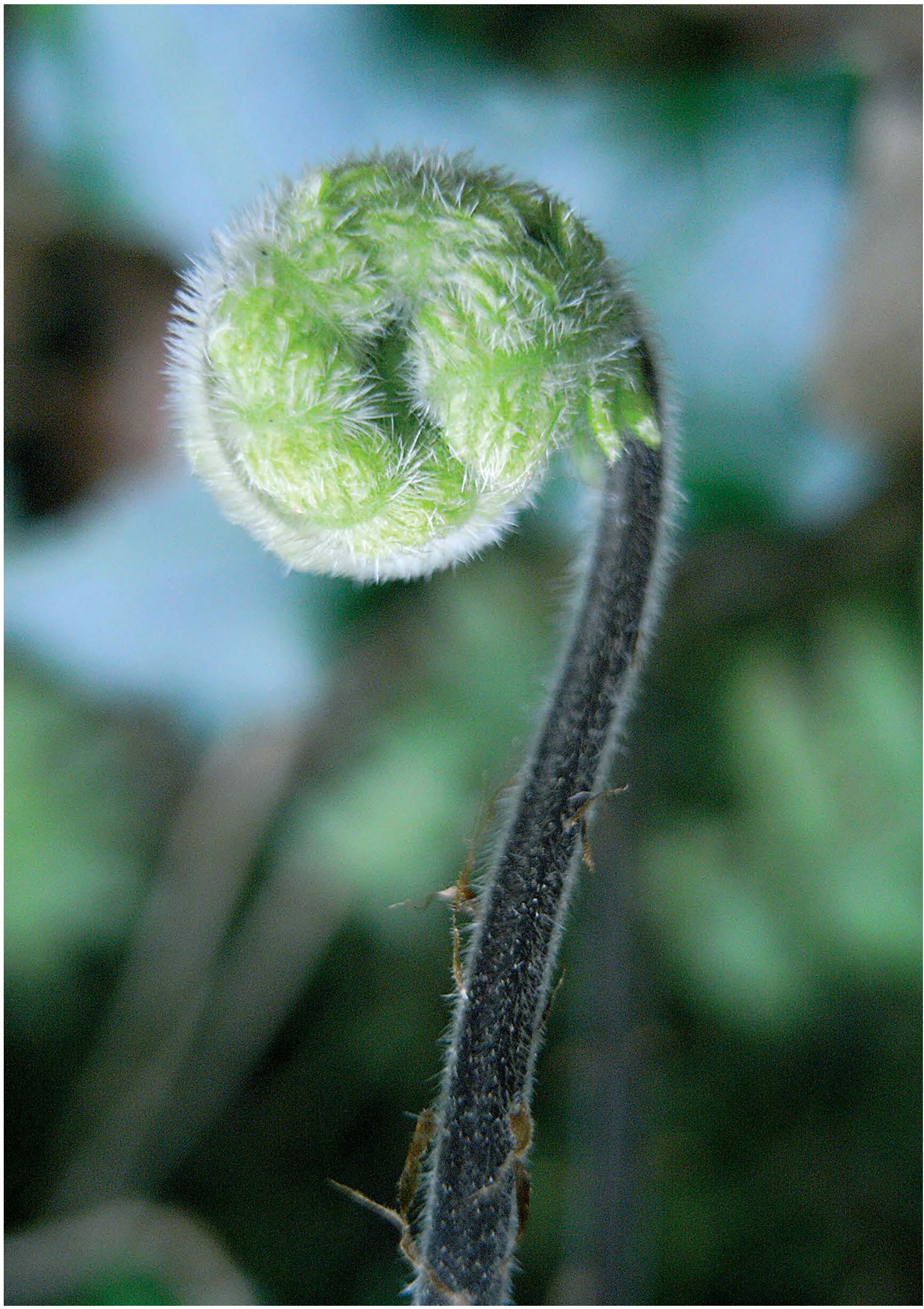




\section{Background}

\subsection{The European context}

Europe is the world's second smallest continent in terms of area after Australia, covering approximately 10.4 million $\mathrm{km}^{2}$, or $2 \%$ of the Earth's surface. In terms of human population, Europe is the third largest continent (after Asia and Africa) with a population of around 740 million (UN DESA 2015) - about $11 \%$ of the world's population. Europe has the most highly urbanised population and, together with Asia, is the most densely populated continent in the world.

The European Union (EU), consisting of 28 Member States, is Europe's largest political and economic entity. It is the world's largest economic block with an estimated gross domestic product (GDP) in 2014 of $€ 13.9$ trillion for the EU 28 Member States (Eurostat 2015). Percapita GDP in many EU states is among the highest in the world, and rates of resource consumption and waste production are correspondingly high - the EU 28's "ecological footprint" has been estimated to exceed the region's biological capacity (the total area of cropland, pasture, forest, and fishing grounds available to produce food, fibre and timber, and absorb waste) by 2.6 times (EEA 2015).

Europe contains areas of great diversity of landscapes and habitats and a wealth of flora and fauna. European biodiversity includes around 20,000 species of vascular plants (Euro+Med 2006-2016), 530 species of birds (BirdLife International 2015), 260 species of mammals (Temple and Terry 2007), 151 species of reptiles (Cox and Temple 2009), 85 species of amphibians (Temple and Cox 2009), 546 species of freshwater fishes (Freyhof and Brooks 2011), 1,220 species of marine fishes (Nieto et al. 2015), 138 species of dragonflies and damselflies (Kalkman et al. 2010), and well over 100,000 other species groups of invertebrates (de Jong et al. 2014). The Mediterranean Basin, which is especially rich in plant and animal species, many of them endemic, has been

Figure 1. European assessment boundaries*.

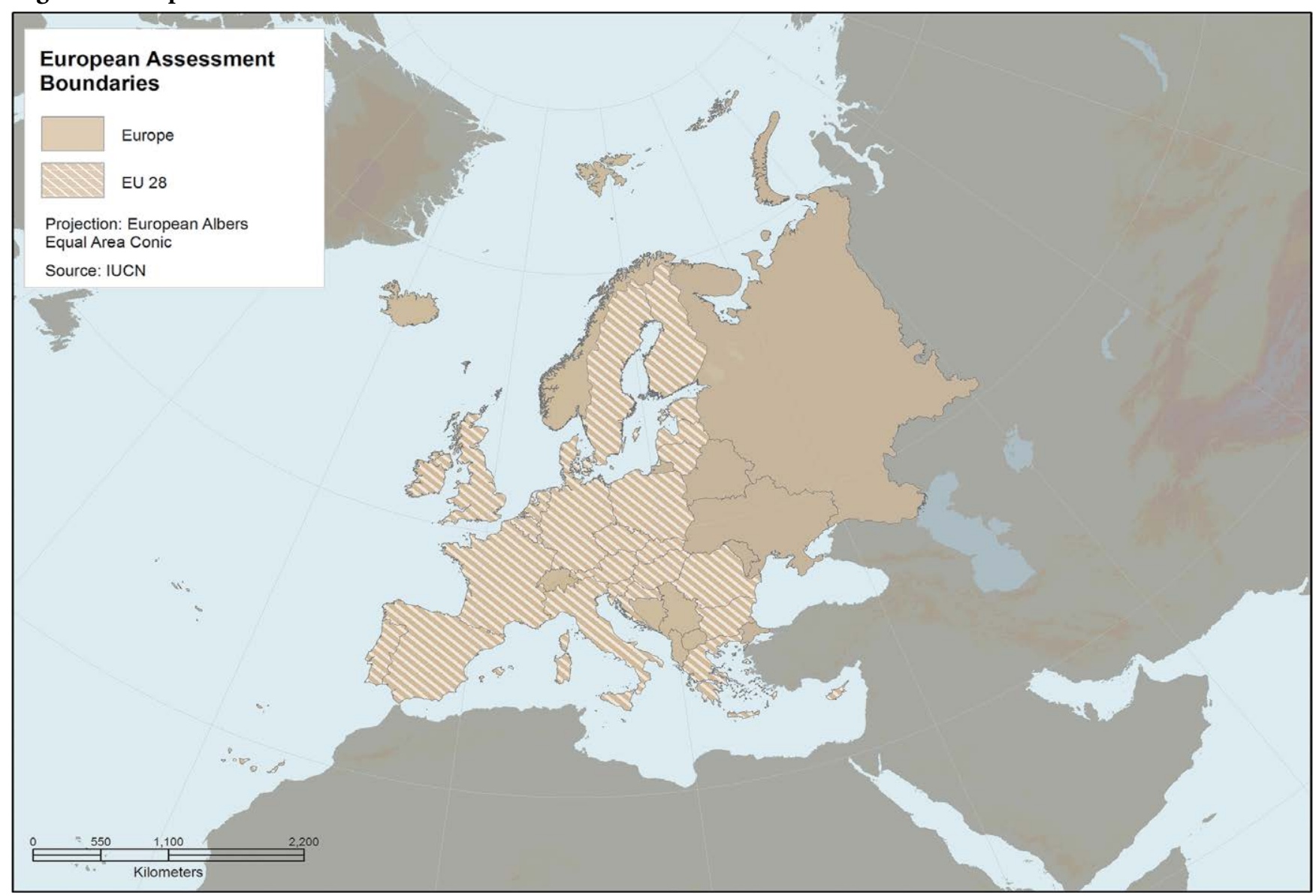

${ }^{*}$ Regional assessments were made for two areas: geographical Europe and the EU 28. 
recognised as a global biodiversity hotspot (Mittermeier et al. 2004, Cuttelod et al. 2008).

The European continent has a highly fragmented landscape, and only a minuscule fraction of its land surface can be considered as wilderness, with wilderness protected areas covering around $4 \%$ of the Natura 2000 network (European Union 2013). For centuries, most of the European land mass has been used by humans to produce food, timber and fuel, and to provide living space, which has resulted into large areas being now urbanised. Up to $80 \%$ of land in Europe is currently used for settlement, industry, production systems (including agriculture and forestry) and infrastructure (EEA 2016). Consequently, European species are to a large extent dependent upon habitats created and maintained by human activity, particularly traditional, non-intensive forms of land management. These habitats are under pressure from agricultural intensification, commercial forestry, urban sprawl, infrastructure development, land abandonment, human-induced fires, acidification, eutrophication and desertification. Many species are affected by overexploitation, persecution and the impacts of invasive alien species, and climate change is set to become an increasingly serious threat. Europe is a large, diverse region and the relative importance of different threats varies widely across its biogeographic regions and countries.

Although considerable efforts have been made to protect and conserve European habitats and species (see Sections 4.1 and 4.2), and the Natura 2000 network of protected areas covers more than $18 \%$ of the EU terrestrial territory, biodiversity decline and the associated loss of vital ecosystem services (such as water purification, pollination, flood protection and carbon sequestration) continues to be a major concern in the region.

\subsection{European lycopods and ferns}

This project is focused on spore-producing vascular plants, which are composed of two distantly related lineages called lycopods and ferns. Since they both produce spores and have a similar life cycle, in the past they were usually united under the name 'pteridophytes' or 'ferns and fern allies'. However, these groups are not monophyletic (they do not share the most recent common evolutionary ancestor or ancestral group) since ferns are more closely related to seed plants than to lycopods.

\section{Life history}

Unlike seed plants, the life cycle of ferns and lycopods has two free-living stages, the sporophyte and the gametophyte. Sporophytes are the larger, complex plants that produce spores in sporangia, often aggregated in sori. In most ferns these are formed on the lower side of the leaf blade and in lycopods mostly in leaf axils. When landed in a suitable spot, the spores germinate into a gametophyte, a simple structure that produces female and male gametes (reproductive cells), the latter with flagellae that allow them to swim to the female gametes, usually in a thin film of water. When fertilisation has been successful, a new sporophyte develops and the gametophyte withers away. This peculiar life cycle is called the 'alternation of generations'. Many ferns and lycopods also reproduce vegatatively via proliferous buds or bulbils on leaves, stems, rhizomes or on gametophytes.

Alternation of generations in ferns. (C) Jeffrey Finkelstein (CC-BY-SA-3.0 or CC BY-SA 2.5-2.0-1.0)

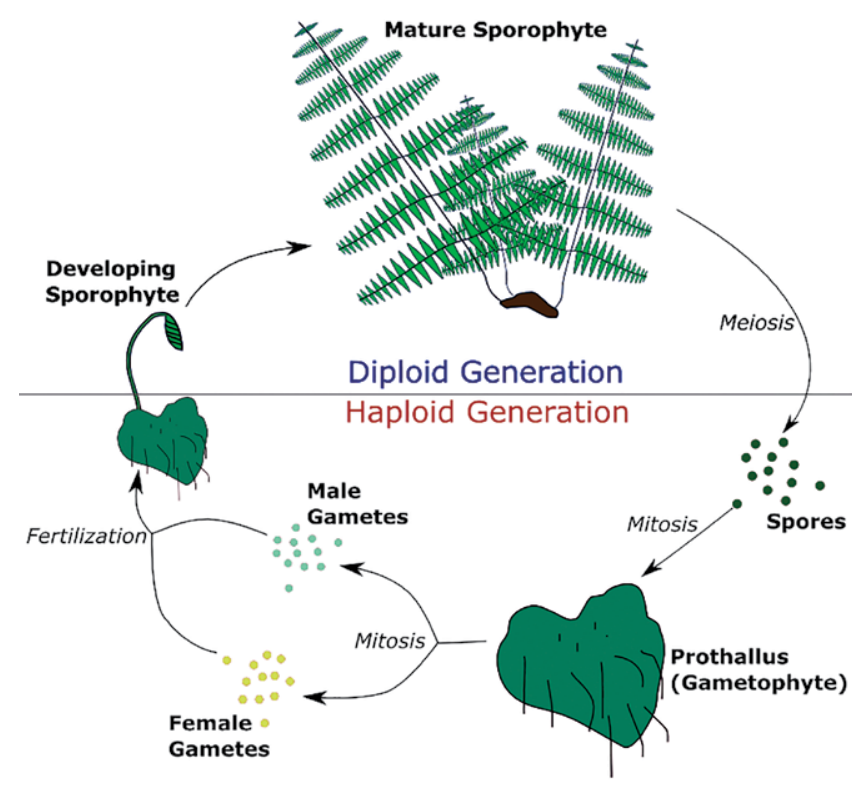

\section{Lycopods}

Lycopods (class Lycopodiopsida) date back to the Silurian period (ca 425 million years ago; Rickards 2000) and they were the first dominant vascular land plants on Earth. Together with algae, liverworts, mosses, hornworts, ferns and early lineages of plants that are now extinct, they were responsible for the fixation of carbon in coal, oil and natural gas, and as such fixed large amounts of carbon dioxide from the atmosphere, making the air breathable and tempering the climate. Lycopods had a much greater diversity in the past than today, but this does not make the modern species 'living fossils. These are as well adapted as their flowering plant counterparts and many are recently evolved taxa, which have arisen in the 


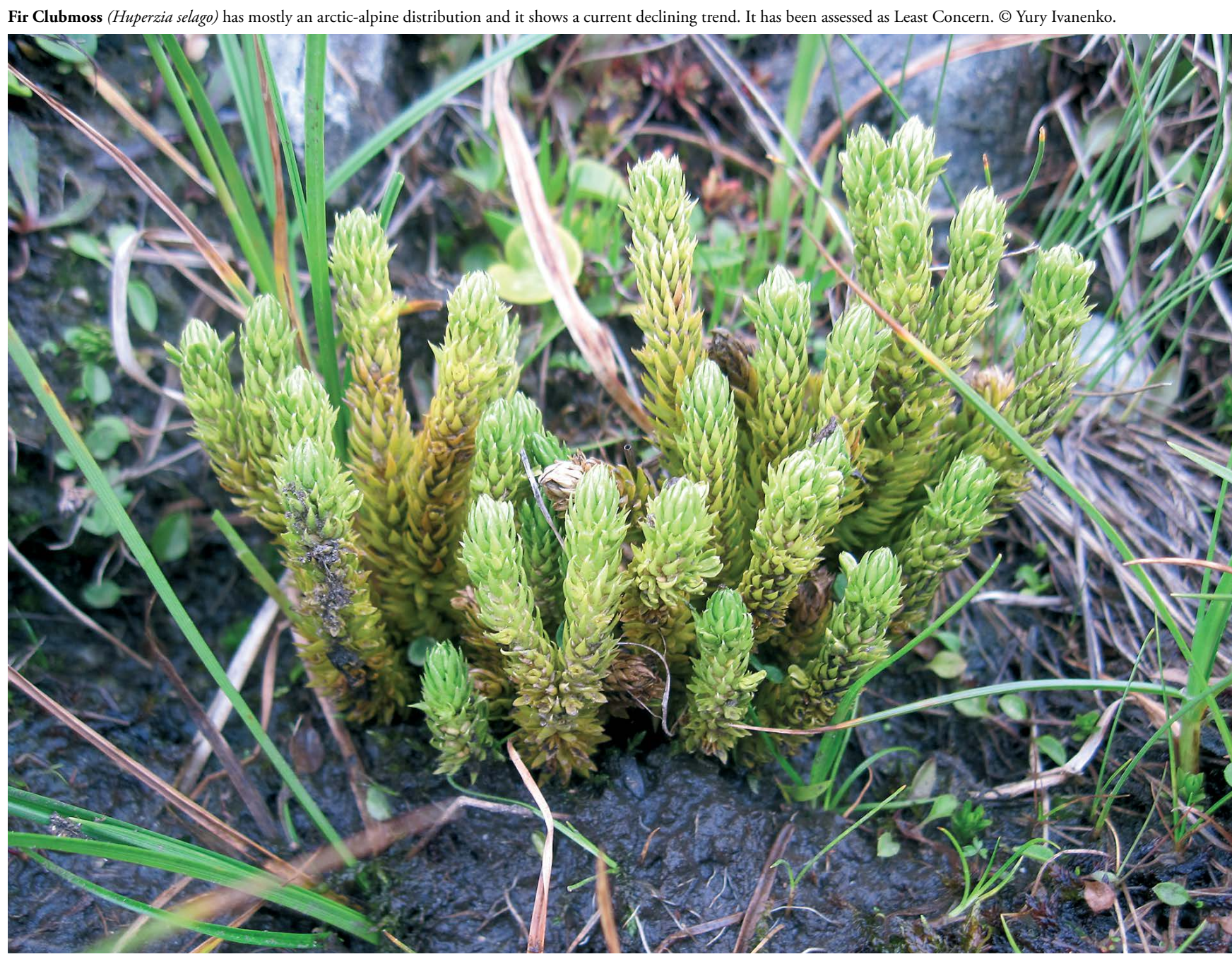

new habitats formed by seed plants. An exception may be Selaginellaceae, since Permian Selaginella harrisiana (aged ca 273 million) has a full set of extant Selaginella characteristics (Stewart and Rothwell 1993).

Lycopods are subdivided into three families: Lycopodiaceae (clubmosses), Selaginellaceae (spikemosses) and Isoëtaceae (quillworts). Terrestrial Selaginellaceae and aquatic Isoëtaceae are unique in having two types of spores (large and small ones), where the gametophyte develops inside the spore wall, and is possibly an adaptation to adverse environmental conditions in order to better protect small gametophytes. Endosporic germination can also be found in families of aquatic ferns (Marsileaceae and Salviniaceae). Following Christenhusz and Raab-Straube (2013), Lycopodiaceae are composed of three genera: Huperzia, Lycopodiella and Lycopodium, which differ in characters of branching patterns, the presence or absence of modified leaves, spore morphology, gametophyte shape and chromosome number. Lycopods differ from other vascular plants in having microphylls, simple leaves with only one central vein. Many lycopods have subterranean gametophytes that make an obligatory association with fungi (Merckx et al. 2012). Spores of lycopods with these subterranean gametophytes need some disturbance of the ground cover to penetrate into the soil, which is why colonisation of abandoned gravel and sandpits or soil following forest fires is often successful.

\section{Ferns}

Globally, ferns (class Polypodiopsida) are subdivided into 11 orders, with a total of 21 families and some 215 genera (Christenhusz and Chase 2014), but the concept of families and genera in ferns remains a matter of controversy, with some authors preferring a higher degree of splitting (e.g., PPG I 2016). Polypodiales is the largest order encompassing most ferns, in which Polypodiaceae (ca 4,080 species; Christenhusz and Byng 2016) is the most species-rich family.

In general, ferns are distinguished from lycopods by having megaphylls, leaves that are usually supported by more than a single vein, often called 'fronds' to distinguish them from leaves of seed plants. Most extant ferns have sporangia on the underside of the leaf, although separate structures presenting the spores are common in several 
lineages. The vascular system is also usually more complex than in lycopods.

Ferns first appeared in the fossil record some 360 million years ago (during the Devonian Period), but most modern lineages of ferns are considerably younger, appearing during the Cretaceous ( $c a 145$ million years ago). They evolved after flowering plants became dominant, creating many new habitats allowing remaining fern lineages to diversify (Schneider et al. 2004). Most ferns therefore should also not be described as 'living fossils', possibly with the exception of horsetails (Equisetaceae), which have morphologically changed little for at least 250 million years. Fossil specimens are easily recognisable as a member of the modern genus Equisetum, possibly the oldest extant plant genus on Earth (M. Christenhusz pers. comm. 2017, in prep.).

\section{Distribution, habitats and ecology}

Ferns and lycopods occur in many different habitats, from mangrove forests and peat swamps to rocky mountain peaks and open deserts, but are most diverse in misty, humid tropical and subtropical cloud forests at mid elevations. The adaptations of ferns and lycopods into extreme habitats are noteworthy and in some genera (e.g., Marsilea) the mechanisms of adaptation to submergence and desiccation are similar, with the spores being protected in a hardened structure formed by specially modified leaves. Others have leaves that can recover after desiccation and many species reproduce vegetatively by producing buds on the leaves, allowing them to rapidly colonise new areas.

Although most ferns have green gametophytes that photosynthesize, some species have gametophytes that live exclusively in a parasitic relationship with fungi (mycoheterotrophs) and only produce chlorophyll once a sporophyte is developed (Merckx et al. 2012). These mycoheterotrophic gametophytes are mainly found in Psilotaceae and Ophioglossaceae, which can be problematic for ex situ conservation, particularly for threatened species of moonworts (Botrychium). Some species of filmy ferns (Hymenophyllaceae) have gametophytes that can reproduce vegetatively and some populations rarely or never produce sporophytes. These can be found as gametophyte colonies, well outside the range where sporophytes occur, which have been suggested to be remnants of warmer periods in geological time (Rumsey et al. 1990, Rumsey and Sheffield 1996).
Common Moonwort (Botrychium lunaria) is of ephemeral nature and during some years plants can remain underground without emerging. The species is affected mainly by the loss of its open habitats to successional overgrowth and is currently declining, especially in Fennoscandia. It has been assessed as Least Concern. (C) Fred Rumsey.

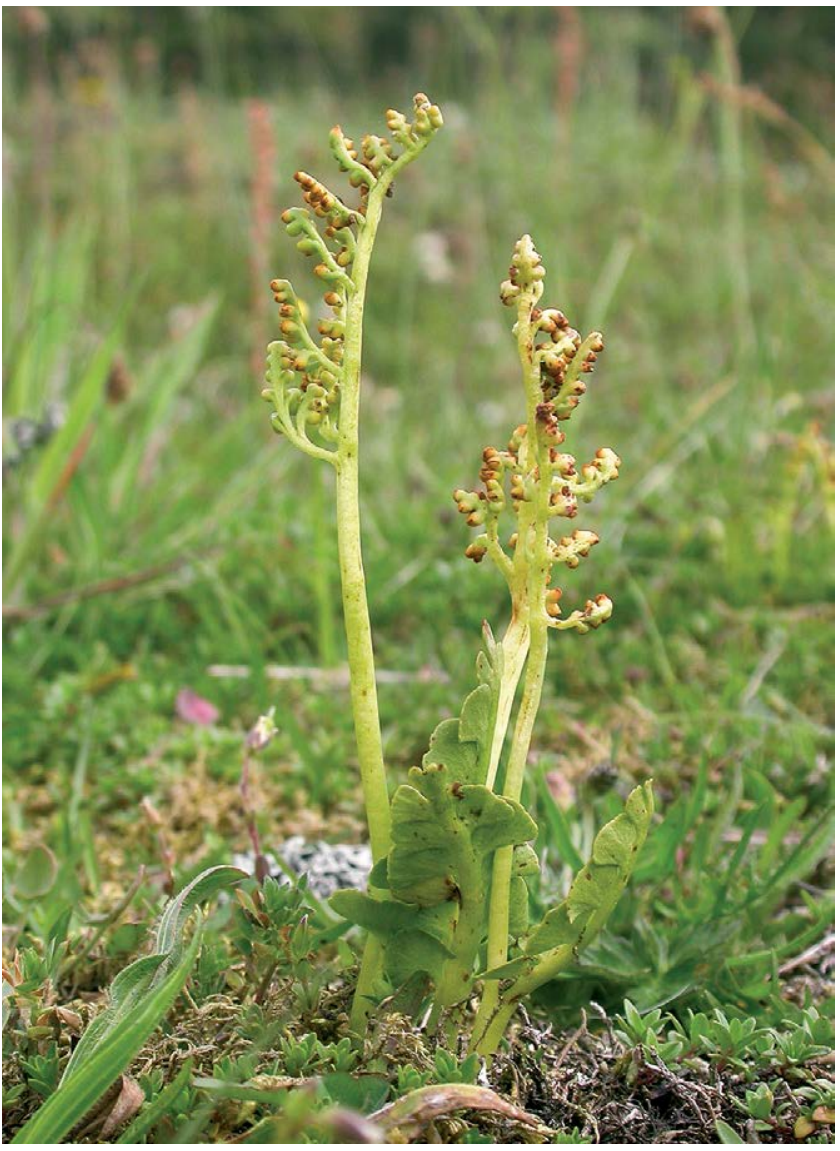

To date, about 10,560 fern species and 1,290 lycopod species (Christenhusz and Byng 2016) have been described worldwide and several dozens of new species are discovered every year. The majority of species are found in the tropics, where they benefit from constant warmth and humidity, with the highest diversity at mid elevations (Kluge et al. 2006). However, ferns and lycopods can be found across the world in any type of habitat, varying from the Arctic tundra to tropical rainforests, from dry deserts to floating or submerged in lakes and rivers. In general, the diversity decreases at higher latitudes and in areas with less precipitation (Hawkins and Diniz-Filho 2004).

In Europe, there is also a clear gradient from east to west, where the more humid Atlantic regions host a higher abundance and number of species (Jalas and Suominen 1972, Christenhusz and Raab-Straube 2013). This need for humidity is directly linked to the life cycle of ferns and lycopods, where water is needed for the free-swimming male gametes to reach the sessile female cells. In addition, gametophytes and some sporophytes (particularly Hymenophyllaceae) have thin layers of tissue that are prone to drying out. Therefore, ferns are usually found in humid environments, such as damp banks and damp 
areas in forests, peat bogs, sides of ditches and streams, inside rocky crevices, edges of wells, on damp walls and other humid places. In the more humid Atlantic regions there are several species that grow epiphytically on mossy branches of trees. This phenomenon is common in the humid tropics, but much less so in temperate regions.

However, there are a number of species in Europe that have developed strategies to survive in harsher, drier conditions, such as vernal pools, steppes and Mediterranean scrub, although in all of these areas there is at least a period of humidity during which they reproduce. In general, most fern species are resilient when their main area of distribution and populations are not under threat. However, some species are sensitive to certain threats, the main ones outlined in Section 3.4.

\section{Ecosystem services and commercial use}

Ferns play essential roles in providing ecosystem services, such as soil erosion prevention, stream bank stabilisation, removal of pollutants from the environment, soil creation on barren habitats, carbon fixation and the provision of shelters and habitat for small animals (Mehltreter et al. 2010). They have also been significantly used for horticultural purposes. Many species, native and exotic, are commonly grown in gardens and specialist collections (Ide et al. 1992).

Fiber from the rhizomes of Royal Fern (Osmunda regalis) was commonly used as an orchid growing medium (Sheehan 1960) and leaves of Maidenhair Fern (Adiantum capillus-veneris) are locally popular for making syrup. Scouring-Rush (Equisetum hyemale) was previously used to scrub pans and other metal objects. Young unfurling leaves of some species can be eaten, particularly those of Ostrich Fern (Onoclea struthiopteris; Yatskievych 2003, Lee and Chin 2011), but carefully and in moderation as some strains of this fern are mildly poisonous and less palatable (May 1978). In addition, some ferns are known for their medicinal properties, such as Adiantum capillus-veneris, whose fronds show antimicrobial activity (Singh et al. 2008) or Equisetum arvense, which is used as

Common Rustyback Fern (Asplenium ceterach) is widespread and locally common, being found in both natural and urban settings. However, the potential effects of climate change on this species need further research. It has been assessed as Least Concern. (C) Maarten Christenhusz.

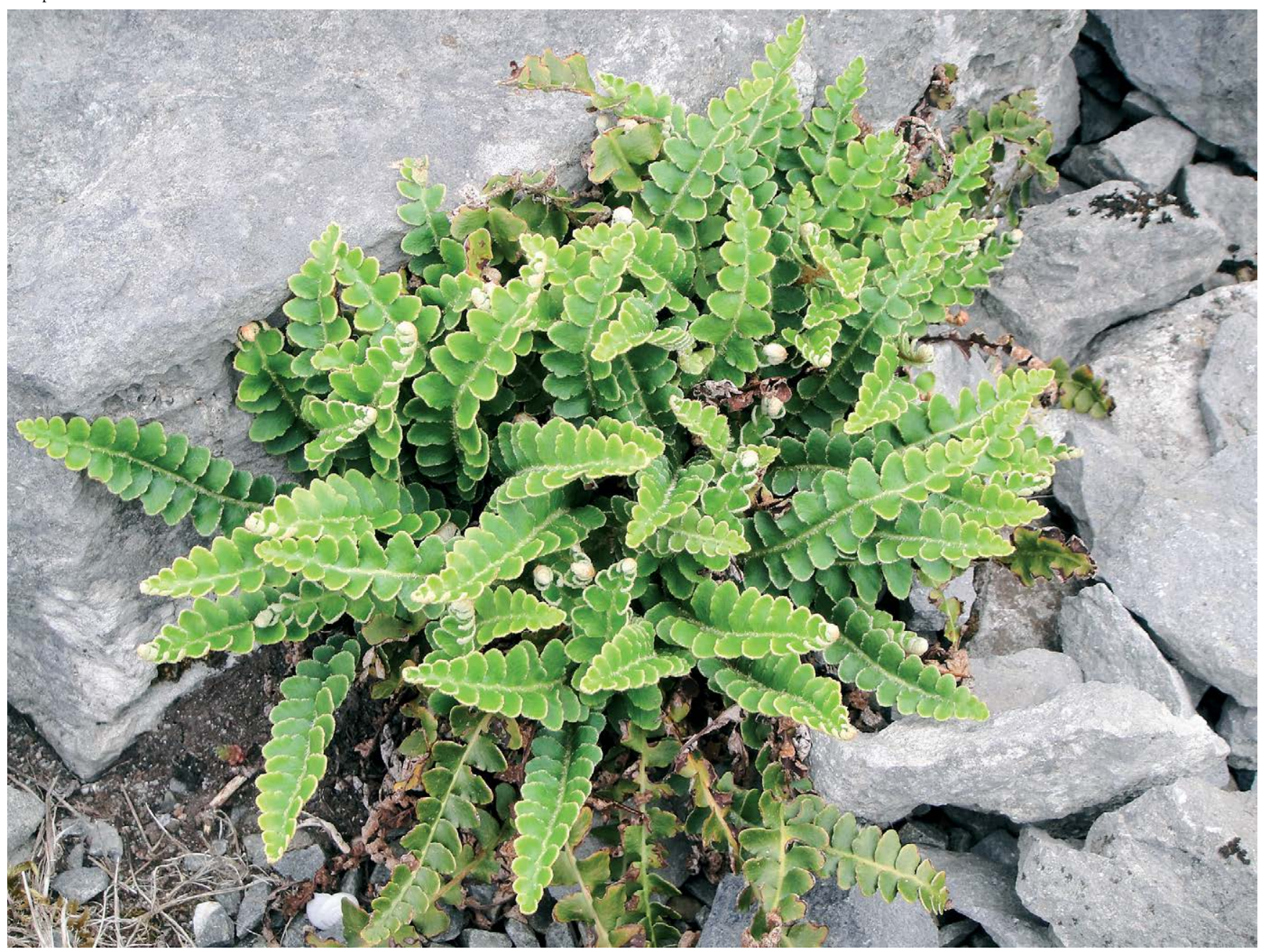


diuretic and remineralisant (Council of Europe 2014), among others.

However, many other ferns are highly carcinogenic, with species such as the Common Bracken (Pteridium aquilinum) having genotoxic, cytotoxic, carcinogenic and immunomodulatory effects on animals and humans (Simán et al. 2000, Tourchi-Roudsari 2014) and it has a long history of poisoning grazing livestock (Cao et al. 2017).

Lycopods are less commonly cultivated, although some Selaginella species, particularly $S$. kraussiana, can be found in the horticultural trade (Ide et al. 1992). The spores of Lycopodium are high in fatty acids and ignite easily. Lycopodium powder was formerly widely collected from the wild and used in flash photography lights. It was also used for powdered surgical gloves, although this may cause allergic reactions in some patients and this practice has now been abandoned (Beaton and Buckland 1975, Field 1997). Some fern and lycopod species have also been used to a smaller extent in the chemical industry as they contain a vast array of interesting chemicals resulting from their long evolutionary history.

\section{Diversity, speciation and endemism}

In Europe, 38 lycopods and 156 ferns were identified, amounting to a total of 194 species. For the purposes of this report, endemic species are those that are known only from the European Assessment Zone (Figure 1). Of the 194 species in Europe, 27.3\% (53 species) are considered endemic to the assessment region based on known, suspected, or inferred occurrences (Table 1). This represents almost a third of the European fern and lycopod flora, with most of these endemic species being found in the Macaronesian region. Most endemic species have relatively small geographical ranges and are restricted to specific habitats.

Ferns are often good colonisers of new habitats, such as rocky slopes, masonry, reclaimed land and lava flows, including newly formed oceanic, volcanic islands. Once these habitats are reached and become isolated, speciation may then take place. The most diverse areas are mid-elevation tropical mountains and oceanic islands (Mehltreter et al. 2010). The higher fern diversity of the Macaronesian islands can be explained by this as the islands are oceanic and in part subtropical. Speciation of ferns frequently happens through allopolyploidy, where two species cross forming a stable hybrid with more sets of chromosomes and thus becomes a genetically isolated new species. While polypoidy is a common feature in various plant groups (Crawford et al. 2005), this particular form of speciation resulting from hybridisation is far more common among ferns than in flowering plants (Wagner and Wagner 1980).

Some ferns, often odd-ploids of hybrid origin, achieve fertility through a subsexual process, creating fewer spores of the same ploidy level as the leafy plant (which means that the spores have the same number of chromosomes as the sporophyte). This creates uniform, essentially clonal lineages, which may interbreed with normal sexual plants creating a multiplicity of forms (microspecies) that are taxonomically problematic. A prime example is the Dryopteris affinis complex, in which many microspecies are known. Recognition of these taxa may strongly affect species numbers, conservation assessments and other analyses based on this. Particularly, their ability to produce sporophytes in the absence of fertilisation allows successful colonisation in drier environments and improves the chances of single spore and longer distance colonisation, giving them an advantage over sexually reproducing taxa. The majority of invasive fern species of urban environments, both native and exotic, show this type of breeding system (Crouch and Rumsey 2010).

\footnotetext{
Maidenhair Fern (Adiantum capillus-veneris) is a widespread species that faces no major threats, although native populations in Britain suffered from collection for horticultural purposes during the fern craze of the $19^{\text {th }}$ Century. It has been assessed as Least Concern. (c) Fred Rumsey.
}

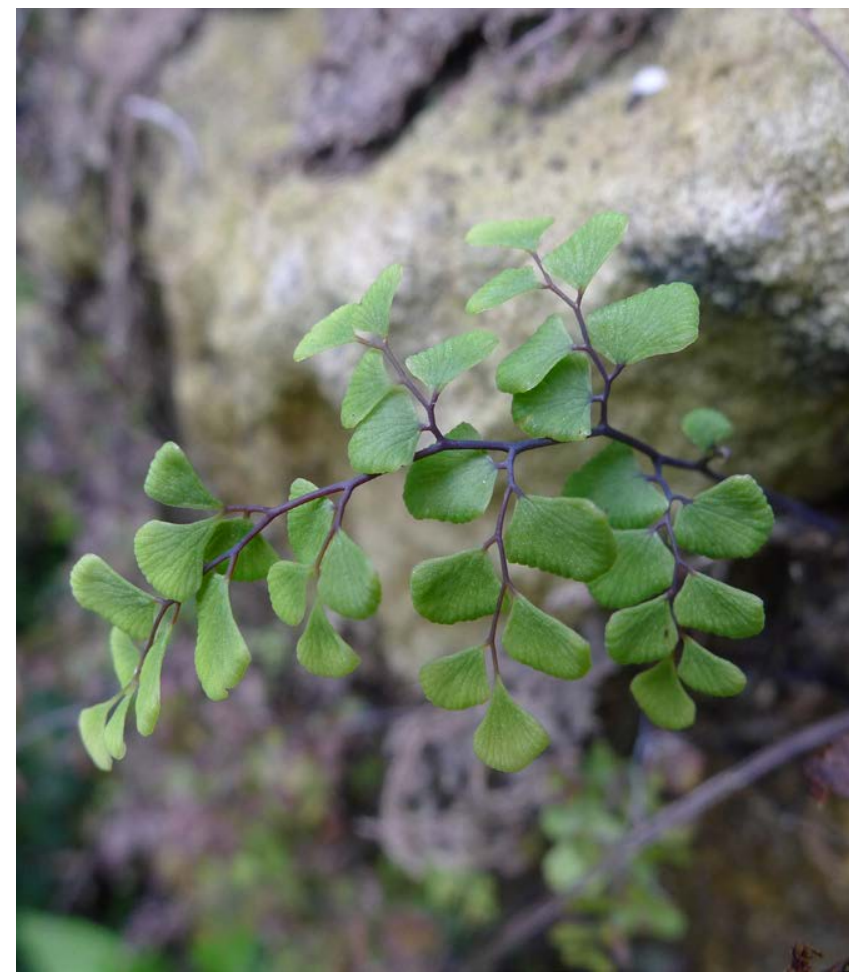


Aspleniaceae, which has a high diversity worldwide, is the most diverse family in Europe with 58 species. This family includes the genus Asplenium, which is the most species-rich genus of ferns in Europe. Aspleniaceae is closely followed by Polypodiaceae (42 species), which is the most species-rich family across the temperate regions of the Northern Hemisphere. Both are highly derived fern families that were able to diversify in the new habitats created by the diversification of angiosperms (Schneider et al. 2004). Many also form allopolyploid species and some produce hybrid swarms, making it difficult to discern between species. Therefore, it is not surprising that the highest number of endemic species belongs to Aspleniaceae (16 species, 27.6\%), Polypodiaceae (14 species, 33.3\%) and Isoëtaceae (13 species, 65\%), the latter due to recent studies in the Mediterranean species of Isoëtes, a genus that was previously poorly known (Troia et al. 2016). Families with only a single native representative species in Europe include Cyatheaceae, Osmundaceae, Psilotaceae and Salviniaceae.

Table 1. Diversity and endemism in lycopod and fern families in Europe.

\begin{tabular}{|c|c|c|c|c|c|}
\hline \multirow[b]{2}{*}{ Species group } & \multirow[b]{2}{*}{ Family } & \multicolumn{2}{|c|}{ Europe } & \multicolumn{2}{|c|}{ EU 28} \\
\hline & & $\begin{array}{c}\text { Number of } \\
\text { species }\end{array}$ & $\begin{array}{l}\text { Number of } \\
\text { endemic species } \\
\text { (\% endemic) }\end{array}$ & $\begin{array}{c}\text { Number of } \\
\text { species }\end{array}$ & $\begin{array}{l}\text { Number of } \\
\text { endemic species } \\
\text { (\% endemic) }\end{array}$ \\
\hline \multirow{3}{*}{ Lycopods } & Isoëtaceae & 20 & 12 & 20 & 11 \\
\hline & Lycopodiaceae & 14 & 3 & 14 & 3 \\
\hline & Selaginellaceae & 4 & 0 & 4 & 0 \\
\hline \multirow{12}{*}{ Ferns } & Aspleniaceae & 58 & 16 & 57 & 12 \\
\hline & Cyatheaceae & 1 & 1 & 1 & 1 \\
\hline & Dennstaedtiaceae & 2 & 1 & 2 & 0 \\
\hline & Equisetaceae & 10 & 0 & 10 & 0 \\
\hline & Hymenophyllaceae & 4 & 2 & 4 & 1 \\
\hline & Marsileaceae & 6 & 2 & 5 & 1 \\
\hline & Ophioglossaceae & 11 & 0 & 11 & 0 \\
\hline & Osmundaceae & 1 & 0 & 1 & 0 \\
\hline & Polypodiaceae & 42 & 14 & 42 & 13 \\
\hline & Psilotaceae & 1 & 0 & 1 & 0 \\
\hline & Pteridaceae & 19 & 2 & 18 & 2 \\
\hline & Salviniaceae & 1 & 0 & 1 & 0 \\
\hline \multicolumn{2}{|l|}{ Total } & 194 & $53(27.3 \%)$ & 191 & $44(23.0 \%)$ \\
\hline
\end{tabular}

\subsection{Assessment of species extinction risk}

The conservation status of plants, animals and fungi is one of the most widely used indicators for assessing the condition of ecosystems and their biodiversity. Conservation status assessments are intended to be policy-relevant and can be used to inform conservation planning and priority setting processes. However, they are not intended to be policy-prescriptive and are not in themselves a system for setting biodiversity conservation priorities. At the global scale, the primary source of information on the conservation status of plants and animals is the IUCN Red List of Threatened Species ${ }^{\mathrm{TM}}$ (www.iucnredlist.org).
The IUCN Red List Categories and Criteria (IUCN 2012a) are designed to determine the relative risk of extinction of a taxon, with the main purpose of cataloguing and highlighting those taxa that are facing a higher risk of extinction. The IUCN Red List provides information on taxonomy, distribution, ecology, threats and conservation status of taxa that have been evaluated using the IUCN Categories and Criteria.

The IUCN Red List Categories (Figure 2) are based on a set of quantitative criteria linked to population trends, size and structure, and geographic ranges of species. There are nine categories, with species classified as Vulnerable (VU), Endangered (EN) or Critically Endangered (CR) 
considered as "threatened". When conducting regional or national assessments, the IUCN Red List Regional Guidelines (IUCN 2012b) are applied and two additional categories are used: Regionally Extinct (RE), and Not Applicable (NA) (Figure 2). No species were assessed as Not Applicable on this Red List, but one of them was assessed as Regionally Extinct.

As the extinction risk of a species can be assessed at global, regional or national levels, a species may have a different Red List category in the global Red List than in the regional Red List. For example, a species that is common worldwide and classed as Least Concern (LC) in the global Red List could face a high level of threat in a particular region and therefore be listed as threatened in the regional Red List. Logically, an endemic species should have the same category at regional and global levels, as it is not present anywhere else in the world

\subsection{Objectives of the assessment}

The European Red List of Lycopods and Ferns has four main objectives:

- to contribute to regional conservation planning through provision of a baseline dataset reporting the conservation status of European lycopod and fern species;

- to identify those priority geographic areas and habitats needing to be conserved to prevent extinctions and to ensure that European lycopods and ferns reach and maintain a favourable conservation status;

- to identify the major threats and to propose potential mitigating measures and conservation actions to address them;

- to strengthen the network of experts focused on lycopod and fern conservation in Europe, so that the assessment information can be kept current and expertise can be targeted to address the highest conservation priorities.

The assessment provides three main outputs:

- summary reports on the status of all 194 European lycopod and fern species;

- a freely available database holding the baseline data for monitoring the status and distribution of European lycopods and ferns;

- a website and data portal (http://ec.europa.eu/ environment/nature/conservation/species/redlist and www.iucnredlist.org/initiatives/europe) showcasing these data in the form of species factsheets for all European lycopods and ferns included in this study, along with background and other interpretative material.

The data presented in this report provide a snapshot based on the knowledge available at the time of writing. The database will continue to be updated and made freely and widely available.

Figure 2. The IUCN Red List Categories at the regional scale.

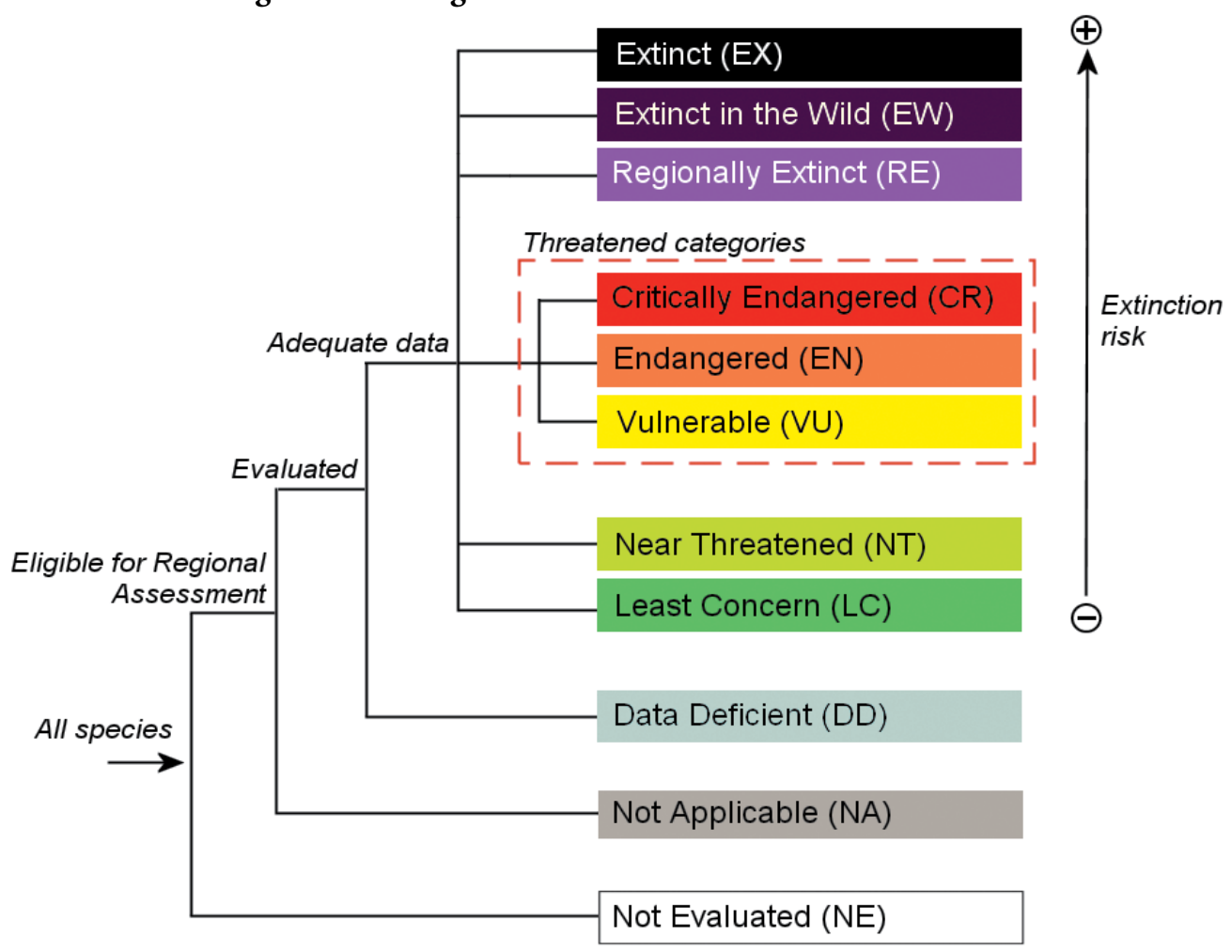




\section{Fern folklore and classification}

The biology of ferns was long misunderstood. Across Medieval Europe, flowers in ferns were expected to appear at some time of the year due to their fairly normal plant appearance. However, since flowers were never seen, people assumed that they had to be invisible. Some folklore even states that ferns only produce seeds on Midsummer night, when they could be collected. A common belief was that ferns had seeds and that the possession of these would make the owner invisible, it was even adopted in Shakespeare's play Henry IV (1597), where the thieves claim to "have the receipt of fern-seed, we walk invisible" (Act 2, Scene 1). It was also thought that the devil was after the power of invisibility, and thus it would have to be repelled in order to collect these precious invisible seeds (In ' $t$ Veld 1981). Furthermore, according to Slavic mythology, the finders of fern flowers during Ivan Kupala night will be rich and happy for the rest of their lives (RBTH 2014).

It was only when Lindsay (1794) took some 'fern dust' (i.e., spores) and sowed it on wet soil, that the development of gametophytes and new fern plants were first observed. This was done 41 years after Carolus Linnaeus published his Species plantarum, in which he placed ferns and lycopods among other 'cryptogams', plants that had an unknown sex life and were thus impossible to place in his 'systema sexualis' (Linnaeus 1753, 1754). Initially, classifications were based on single characters (e.g., Smith 1793, Swartz 1801, Desvaux 1827), often placing unrelated taxa together and resulting in unnatural circumscriptions. This caused a lack of traditional concepts of genera and families in fern classification. This was pointed out by authors like Presl $(1836,1845,1851)$, Smith $(1841,1843)$ and Fée (1844-1873) who included more vegetative characters and compared entire plants to arrive at a better classification of ferns.

Nevertheless, many groups remained problematic and could only be resolved with the advent of molecular systematics, where certain plastid genes could be compared and analysed into phylogenetic trees (e.g., Hasebe et al. 1993, Lehtonen 2011). This allowed scientists to disentangle convergent groups that have morphological similarities due to environmental stresses but are not directly related, and allowed a reorganisation of families and genera.

Parsley Fern (Cryptogramma crispa) occurs in the more montane areas of Europe and Asia. Although in the past it has been affected by mining, eventually this could be beneficial to the species since it is able to invade screes formed by old mine spoils once stabilised. It has been assessed as Least Concern. (C) Fred Rumsey.

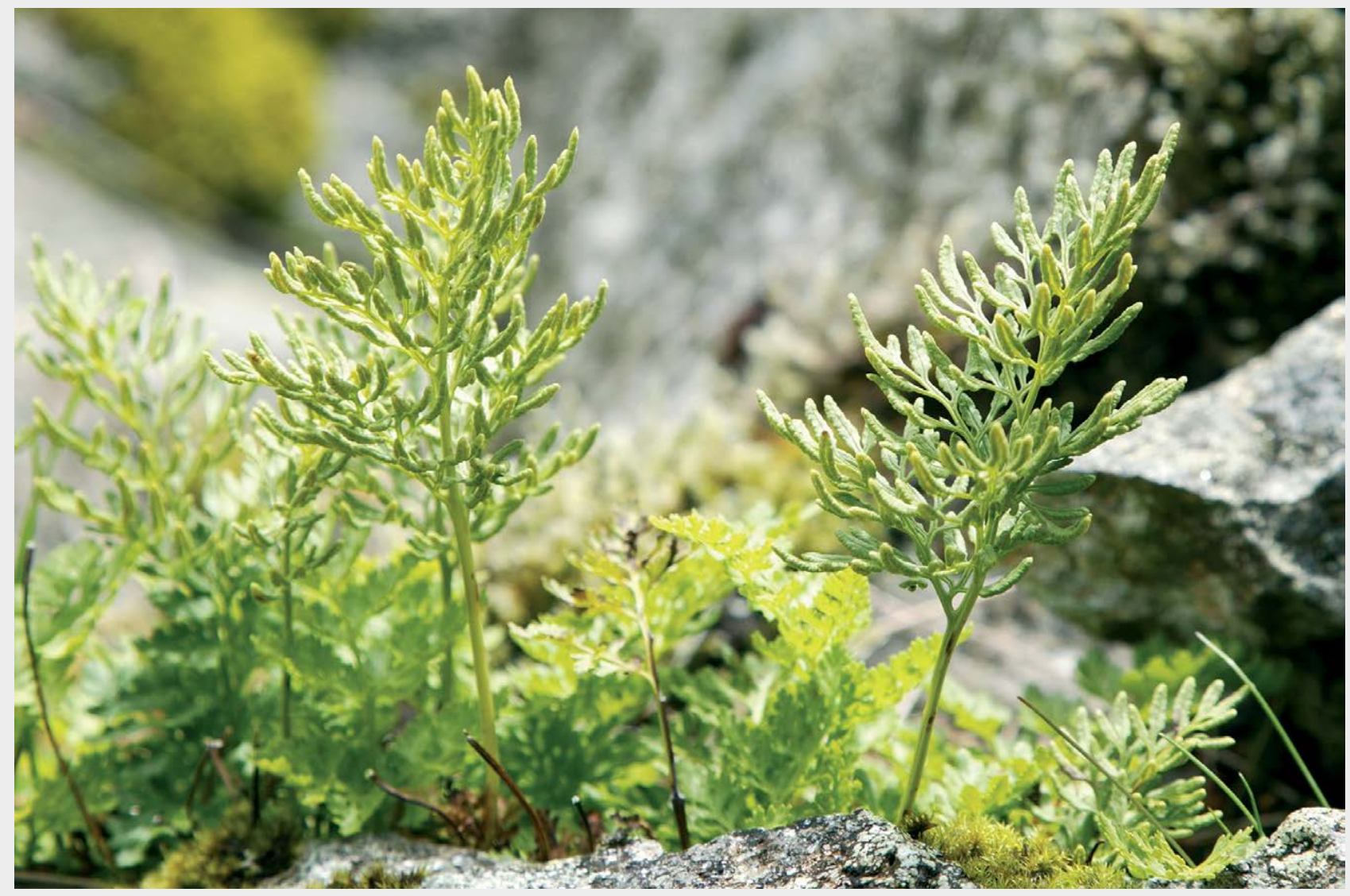




\section{Assessment methodology}

\subsection{Geographic scope}

The geographical scope is continent-wide, extending from Iceland in the west to the Urals in the east (including European parts of the Russian Federation), and from Franz Josef Land in the north to the Mediterranean in the south (Figure 1). The Canary Islands, Selvagens, Madeira, the Azores, Malta and Cyprus are also included. In the southeast, the Caucasus region and Anatolia are excluded.

Red List assessments were made at two regional levels: 1) for geographical Europe (limits described above); and 2) for the area of the 28 Member States of the European Union. At the time of publication, the United Kingdom is an EU Member State.

\subsection{Taxonomic scope}

The European Red List of Lycopods and Ferns has assessed the status of all lycopod and fern species native to Europe or naturalised there before $\mathrm{AD} 1500$. The original list of species was based on the Euro+Med Checklist (Christenhusz and Raab-Straube 2013) for the species and genus taxonomy, and on Christenhusz and Chase (2014) for the familial and ordinal classification. Amendments were made and the inclusion of newly described or modified taxa was undertaken following consultation with the relevant experts. When there were discrepancies in the identity of a species, consultation was sought among the different specialists and decisions were made through consensus. The taxonomy used in the European Red List of Lycopods and Ferns reflects the available taxonomy accepted at the time. All non-native species were excluded from the assessment, but more information on their distribution can be found in Christenhusz and Raab-Straube (2013).

In addition, 35 of these species were previously assessed as part of the European Red List of Vascular Plants (Bilz et al. 2011), and six species were assessed as part of the European Red List of Medicinal Plants (Allen et al. 2014). These have been re-assessed as part of this project.

\subsection{Assessment protocol}

For all the lycopod and fern species assessments, the following data were compiled:
- Taxonomic classification and notes

- Geographic range and list of countries of occurrence (including a distribution map)

- Population information and overall population trends

- Habitat preferences and primary ecological requirements, including pertinent biological information (e.g., generation length, maximum size and age, etc.)

- Species use and trade

- Major threats

- Conservation measures (in place and needed)

- Other general information

- IUCN Red List Category and Criteria and rationale

- Key literature references

The task of collecting the initial data was divided taxonomically. The experts collected information on each species based on published and unpublished data and their personal expert knowledge. The IUCN Species Information Service (SIS) was used to enter and store all species data.

A training workshop was held in October 2015 in order to train the experts on the IUCN Red List methodology. After the preliminary information was collected, one assessment workshop was held to review and discuss all the assessments and distribution maps, add new information to the assessments, and agree on the final IUCN Red List Category and Criteria for the species. This workshop was held in Brussels (Belgium) in June 2016 and was attended by seven experts.

Following the workshop, the information was edited accordingly and the remaining questions were resolved through communications with the experts. An additional peer-review process was ensured by including independent reviewers that had not been previously involved in the assessment process. Consistency in the use of IUCN Criteria was checked by IUCN staff. The resulting finalised IUCN Red List assessments are a product of scientific consensus concerning species status and are supported by relevant literature and data sources.

\subsection{Species mapping}

Distribution information was mainly based on the digital data provided by Atlas Florae Europaeae (Jalas and Suominen 1972) and was complemented with distribution 


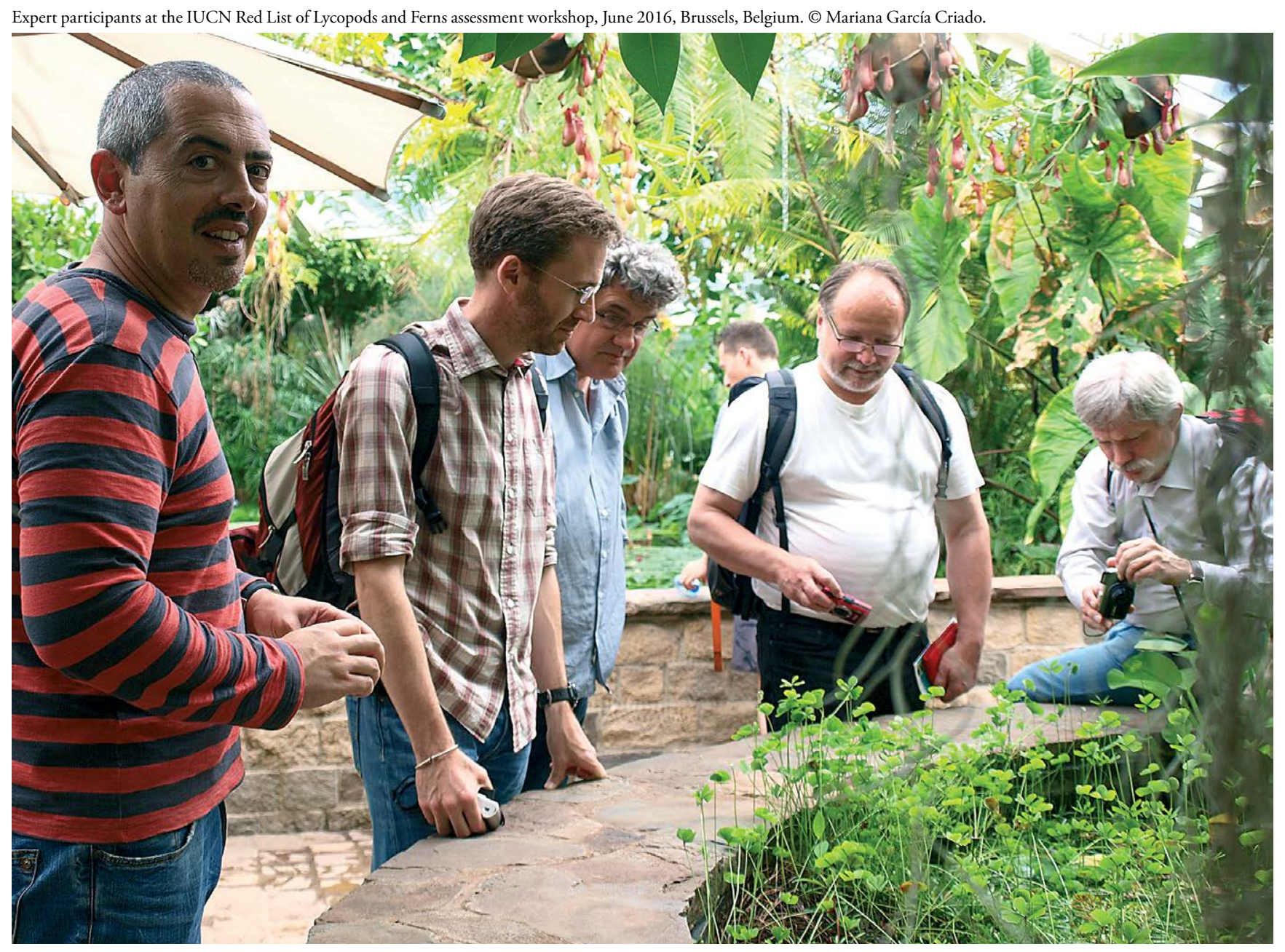

data available from published literature, herbarium specimens, internet sources (e.g., GBIF) and several global and regional citizen science projects. The species experts provided the distribution data to the Ministry of Environment of the Czech Republic (MZP) in order to produce the maps and these were finalised by IUCN.

Range maps were created using the distribution data available, which varied in terms of quality; for some regions, distributional data were available as point locality data (latitude/longitude) or in grid cell format, and were therefore spatially precise. Where point or grid data were available, these were projected in a Geographical Information System (GIS) (ESRI ArcMap). Polygons were then drawn manually, clustering occurrence data where appropriate. In some rare cases where no point data was available and it was only possible to assign presence at the country level, the distribution was mapped for the whole country.

The spatial analyses presented in this publication (see section 3.3) were done using a geodesic discrete global grid system, defined on an icosahedron and projected to the sphere using the inverse Icosahedral Snyder Equal
Area (ISEA) Projection (S39). This corresponds to a hexagonal grid composed of individual units (cells) that retain their shape and area $\left(864 \mathrm{~km}^{2}\right)$ throughout the globe. These are more suitable for a range of ecological applications rather than the most commonly used rectangular grids (S40). The extant and possibly extant (resident) distributions (IUCN 2014) of each species were converted to the hexagonal grid for the purposes of the analysis. Coastal cells were clipped to the coastline.

Patterns of species richness (191 species) (Figure 5) were mapped by counting the number of species in each cell (or cell section, for species with a coastal distribution). Patterns of endemic species richness ( 54 species) were mapped by counting the number of species in each cell (or cell section for coastal species) that were flagged as being endemic to geographic Europe as defined in this project (Figure 6). Patterns of threatened species richness (Categories CR, EN, VU at the European regional level, 36 species) (Figure 7) were mapped by counting the number of threatened species in each cell or cell section. Finally, an analysis of the distribution patterns of Data Deficient species (seven species) was performed by counting the number of Data Deficient species within each cell (Figure 8). 


\section{Results}

\subsection{Threat status}

The extinction risk of lycopods and ferns was assessed at the European level. As a result, $19.9 \%$ of lycopod and fern species are considered threatened (i.e., assessed as having an elevated risk of extinction) in Europe. However, the proportion of threatened species is uncertain given the number of Data Deficient (DD) species and could lie between $19.2 \%$ (if all DD species are not threatened) and $22.8 \%$ (if all DD species are threatened) for Europe (IUCN 2011, Table 2). The mid-point figure provides the best estimation of the proportion of threatened species (IUCN 2011). In the EU 28, 21.3\% of species are considered to be threatened, with the proportion of threatened species lying between $20.5 \%$ (if all DD species are not threatened) and $24.2 \%$ (if all DD species are threatened).

Table 2. Proportion of threatened lycopods and ferns in Europe and in the EU 28.

\begin{tabular}{|l|c|c|}
\hline & $\begin{array}{c}\text { Europe } \\
\text { \% threat }\end{array}$ & $\begin{array}{c}\text { EU 28 } \\
\text { \% threat }\end{array}$ \\
\hline $\begin{array}{l}\text { Lower bound } \\
(\mathrm{CR}+\mathrm{EN}+\mathrm{VU}) / \\
(\text { assessed - EX) }\end{array}$ & 19.2 & 20.5 \\
\hline $\begin{array}{l}\text { Mid-point } \\
(\mathrm{CR}+\mathrm{EN}+\mathrm{VU}) / \\
\text { (assessed - EX - DD) }\end{array}$ & 19.9 & 21.3 \\
\hline $\begin{array}{l}\text { Upper bound } \\
\text { (CR+EN+VU+DD) / } \\
\text { (assessed - EX) }\end{array}$ & 22.8 & 24.2 \\
\hline
\end{tabular}

In Europe, one species (0.5\%) is assessed as Regionally Extinct (and may prove to be globally extinct, pending further taxonomic study). Ten species (5.2\%) are Critically Endangered, 11 species (5.7\%) are Endangered, and 16 species $(8.2 \%)$ are Vulnerable. A further 26 species (13.4\%) are classified as Near Threatened. For seven species $(3.6 \%)$ there were insufficient data to evaluate their risk of extinction and so they were classified as Data Deficient (Table 3, Figure 3). As more data become available and taxonomic issues clarified, it is possible that some of these species may also prove to be threatened.

In the EU 28, one species (0.5\%) is assessed as Regionally Extinct. 10 species (5.2\%) are Critically Endangered, 11 species $(5.8 \%)$ are Endangered, and 18 species (9.4\%) are Vulnerable. A further 25 species (13.1\%) are classified as Near Threatened. For seven species (3.7\%) in the EU 28 there were insufficient data to evaluate their risk of extinction and so they were classified as Data Deficient (Table 3, Figure 4).

Only seven species were assessed as threatened under Criterion A (based on a population size reduction), highlighting the lack of monitoring in place to estimate percentages of decline, the complication in estimating numbers of plants in a population because of the clonal nature of many species and the difficulty to estimate the generation length of the species, usually due to a very long life history.

Table 3. Summary of numbers of lycopods and ferns within each Red List Category.

\begin{tabular}{|lcc|}
\hline IUCN Red List Categories & $\begin{array}{c}\text { No. species Europe } \\
\text { (no. endemic species) }\end{array}$ & $\begin{array}{c}\text { No. species EU 28 } \\
\text { (no. endemic species) }\end{array}$ \\
\hline Extinct (EX) & 0 & 0 \\
\hline Extinct in the Wild (EW) & 0 & 0 \\
\hline Regionally Extinct (RE) & $1(0)$ & $1(0)$ \\
\hline Critically Endangered (CR) & $10(7)$ & $10(7)$ \\
\hline Endangered (EN) & $11(8)$ & $11(8)$ \\
\hline Vulnerable (VU) & $16(9)$ & $18(9)$ \\
\hline Near Threatened (NT) & $26(10)$ & $25(8)$ \\
\hline Least Concern (LC) & $123(17)$ & $7(19)$ \\
\hline Data Deficient (DD) & $7(2)$ & $\mathbf{1 9 1}(\mathbf{4 4})$ \\
\hline Total number of species assessed & $\mathbf{1 9 4 ( 5 3 )}$ & \\
\hline
\end{tabular}


By contrast, 21 species were assessed as threatened under Criterion B (based on geographic range), given that distribution information is generally available for the species. Further data on the population structure, trend and fluctuations and on the extent of threats are used in order to assess species under this Criterion. In addition, 16 species were identified as threatened under Criteria $\mathrm{C}$ and $\mathrm{D}$ due to a small population size. However, it remained difficult to identify the number of mature individuals in a population since some species are clonal (e.g., Lycopodium tristachyum) and some others only appear above ground in certain years due to their very specific environmental requirements (e.g., Botrychium spp., Marsilea strigosa, Pilularia minuta).

By comparison with other comprehensive European Red List assessments, 59\% of freshwater molluscs,

Figure 3. IUCN Red List status of lycopods and ferns in Europe.

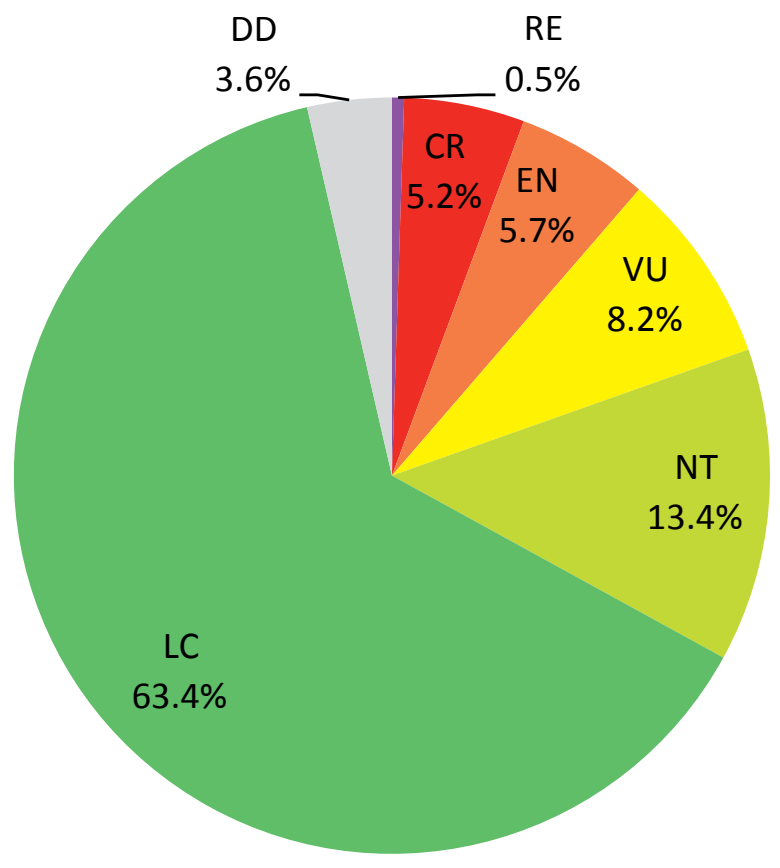

$40 \%$ of freshwater fishes, $28.5 \%$ of grasshoppers, crickets and bush-crickets, $23 \%$ of amphibians, $20 \%$ of reptiles, $17 \%$ of mammals, $16 \%$ of dragonflies, $13 \%$ of birds, $9 \%$ of butterflies and bees, $8 \%$ of aquatic plants and $2 \%$ of medicinal plants are threatened (IUCN 2015, Hochkirch et al. 2016). Additional European Red Lists assessing a selection of species showed that $22 \%$ of terrestrial molluscs, $16 \%$ of crop wild relatives and $15 \%$ of saproxylic beetles are also threatened (IUCN 2015). Thus, lycopods and ferns have a similar percentage of threatened species in Europe as reptiles, and are the most threatened group of vascular plants assessed so far.

Fern and lycopod species classed as threatened (Critically Endangered, Endangered or Vulnerable) at the European level are listed in Table 4.

Figure 4. IUCN Red List status of lycopods and ferns in the EU 28.

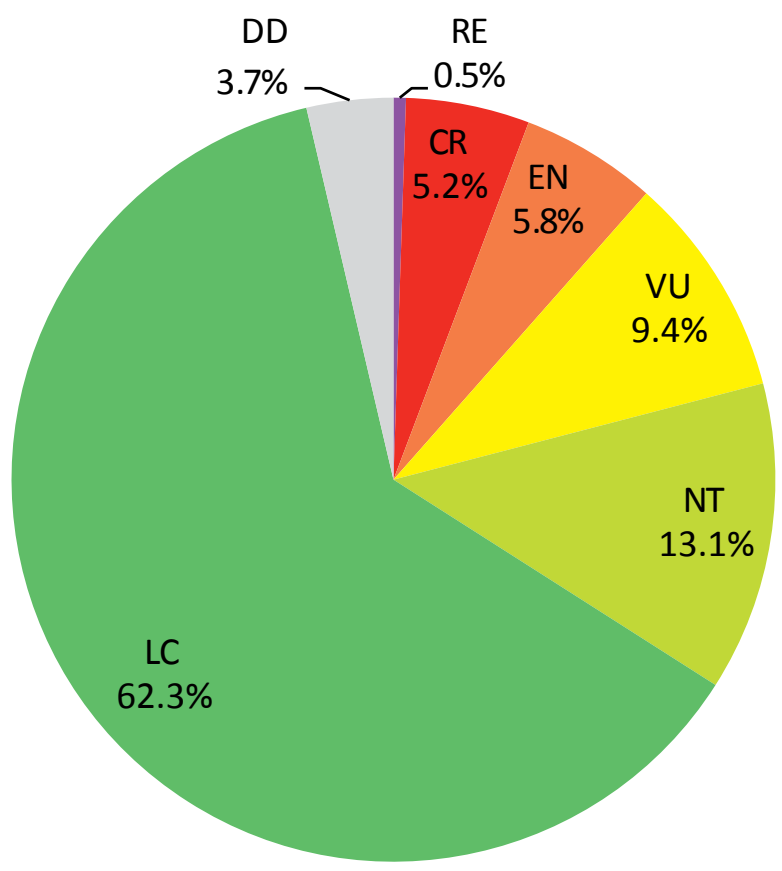


Table 4. Threatened lycopod and fern species at the European level.

\begin{tabular}{|c|c|c|c|c|c|}
\hline \multirow{2}{*}{ Family } & \multirow{2}{*}{ Species } & \multicolumn{2}{|c|}{ Red List status } & \multirow{2}{*}{$\begin{array}{l}\text { Endemic } \\
\text { to Europe? }\end{array}$} & \multirow{2}{*}{$\begin{array}{c}\text { Endemic } \\
\text { to EU 28? }\end{array}$} \\
\hline & & Europe & EU 28 & & \\
\hline Polypodiaceae & Grammitis quaerenda & $\mathrm{RE}$ & $\mathrm{RE}$ & No & No \\
\hline Aspleniaceae & Asplenium auritum & $\mathrm{CR}(\mathrm{PE})$ & $\mathrm{CR}(\mathrm{PE})$ & Yes & Yes \\
\hline Hymenophyllaceae & Hymenophyllum maderense & $\mathrm{CR}$ & $\mathrm{CR}$ & Yes & Yes \\
\hline Isoëtaceae & Isoëtes heldreichii & $\mathrm{CR}$ & $\mathrm{CR}$ & Yes & Yes \\
\hline Isoëtaceae & Isoëtes malinverniana & $\mathrm{CR}$ & $\mathrm{CR}$ & Yes & Yes \\
\hline Isoëtaceae & Isoëtes sabatina & CR & $\mathrm{CR}$ & Yes & Yes \\
\hline Isoëtaceae & Isoëtes todaroana & $\mathrm{CR}$ & $\mathrm{CR}$ & No & No \\
\hline Polypodiaceae & Grammitis azorica & $\mathrm{CR}$ & $\mathrm{CR}$ & Yes & Yes \\
\hline Polypodiaceae & Grammitis jungermannioides & $\mathrm{CR}$ & $\mathrm{CR}$ & Yes & Yes \\
\hline Polypodiaceae & Polystichum drepanum & $\mathrm{CR}$ & $\mathrm{CR}$ & No & No \\
\hline Psilotaceae & Psilotum nudum & CR & $\mathrm{CR}$ & No & No \\
\hline Aspleniaceae & Asplenium anceps & $\mathrm{EN}$ & $\mathrm{EN}$ & Yes & Yes \\
\hline Aspleniaceae & Asplenium terorense & $\mathrm{EN}$ & EN & Yes & Yes \\
\hline Isoëtaceae & Isoëtes boryana & $\mathrm{EN}$ & $\mathrm{EN}$ & Yes & Yes \\
\hline Isoëtaceae & Isoëtes fluitans & $\mathrm{EN}$ & EN & Yes & Yes \\
\hline Isoëtaceae & Isoëtes haussknechtii & $\mathrm{EN}$ & $\mathrm{EN}$ & Yes & Yes \\
\hline Isoëtaceae & Isoëtes tenuissima & EN & $\mathrm{EN}$ & Yes & Yes \\
\hline Marsileaceae & Marsilea batardae & EN & $\mathrm{EN}$ & Yes & Yes \\
\hline Marsileaceae & Pilularia minuta & EN & $\mathrm{EN}$ & No & No \\
\hline Ophioglossaceae & Botrychium simplex & $\mathrm{EN}$ & EN & Yes & Yes \\
\hline Polypodiaceae & Elaphoglossum semicylindricum & $\mathrm{EN}$ & EN & No & No \\
\hline Pteridaceae & Pellaea calomelanos & $\mathrm{EN}$ & $\mathrm{EN}$ & No & No \\
\hline Aspleniaceae & Asplenium aethiopicum & VU & VU & Yes & Yes \\
\hline Aspleniaceae & Asplenium creticum & VU & VU & Yes & Yes \\
\hline Aspleniaceae & Asplenium lolegnamense & VU & VU & Yes & Yes \\
\hline Aspleniaceae & Asplenium majoricum & VU & VU & No & No \\
\hline Aspleniaceae & Woodwardia radicans & VU & VU & No & No \\
\hline Isoëtaceae & Isoëtes azorica & VU & VU & Yes & Yes \\
\hline Isoëtaceae & Isoëtes iapygia & VU & VU & Yes & Yes \\
\hline Lycopodiaceae & Lycopodium madeirense & VU & VU & Yes & Yes \\
\hline Marsileaceae & Marsilea quadrifolia & VU & VU & No & No \\
\hline Marsileaceae & Marsilea strigosa & VU & VU & Yes & Yes \\
\hline Ophioglossaceae & Botrychium lanceolatum & VU & VU & Yes & Yes \\
\hline Ophioglossaceae & Botrychium virginianum & VU & VU & No & No \\
\hline Polypodiaceae & Arachniodes webbiana & VU & VU & No & No \\
\hline Polypodiaceae & Dryopteris ardechensis & VU & VU & No & No \\
\hline Aspleniaceae & Asplenium aegaeum & NT & VU & No & No \\
\hline Aspleniaceae & Cystopteris sudetica & NT & VU & Yes & Yes \\
\hline Aspleniaceae & Asplenium adulterinum & $\mathrm{LC}$ & VU & No & $\mathrm{No}$ \\
\hline Polypodiaceae & Polystichum braunii & $\mathrm{LC}$ & VU & No & No \\
\hline
\end{tabular}

\subsection{Status by taxonomic group}

Table 5 presents the status of European fern and lycopod species organised by family. Compared to the overall proportion of threatened species, the families with the higher proportion of threatened species are Marsileaceae (66.7\%) and Isoëtaceae (52.6\%). In addition, the single species of Psilotaceae in Europe is also threatened, but this is an outlying population of an otherwise pantropical species.

Many of these threatened species are associated with Mediterranean vernal pools, a highly threatened habitat. Isoëtaceae are also known to prefer oligotrophic waters and are thus sensitive to agricultural run-off and other nutrient pollutants that enter the waterbodies they occur 
in. In addition, they are also affected by changes of aquatic regimes. Habitat change is another major threat for Botrychium (Ophioglossaceae), which is a genus that has disappeared from many sites due to changes in land management. The ephemeral nature of the above-ground parts of Botrychium, in combination with its extreme difficulty for ex situ conservation, make the sites where these plants still occur a priority for habitat preservation and site management.

The only Regionally Extinct species is the dwarf epiphyte Grammitis quaerenda, which no longer occurs on the Canary Islands. It is closely related or conspecific with G. ebenina, which occurs on other Atlantic islands like St. Helena and Cape Verde. If they were considered the same species, the name G. quaerenda has priority and is regionally extinct. If they are not the same species then $G$. quaerenda is globally extinct. A genetic study is needed to confirm the identity of the extinct material from the Canary Islands.

Conversely, six families do not include any threatened species in Europe. Many species in these families are common in boreal-temperate forests, some in wetlands and others extending up to the alpine belt. Many species are of a weedy nature or tolerant to disturbance. Soils on which these non-threatened species generally grow are usually moderately moist, within forest areas or on alpine meadows rich in organic matter. Such habitats are common in Europe and many species generally show broad ecological and climatic amplitude.

Regarding the DD species, $42.8 \%$ of these belong to Polypodiaceae, in particular the genus Dryopteris. This is because the taxonomy of Dryopteris has proven to be more complicated since Jalas and Suominen (1972) published their distribution maps. This is in part due to the recognition of novel allopolyploid species, the effects of reticulate evolution (Juslén et al. 2011, Sessa et al. 2015), hybridisation and apomixis, with the resulting difficulties in finding clear morphological distinctions between closely related species. While there are discrepancies on the status of some taxa, respectively treated as species, subspecies or at lower rank, difficulties to differentiate between similarlooking taxa have led to scanty and unreliable data recording and thus these taxa had to be assessed as DD. In the case of Asplenium, where similar taxonomic issues occur, the broad species concept has been followed for the purposes of the assessment, providing an additional Red List assessment for each of the separate subspecies whenever possible.

The status of LC was assigned to all the species of Dennstaedtiaceae (two species), Equisetaceae (ten species), Osmundaceae (one species) and Selaginellaceae (four species). Families with a high proportion of LC species include Pteridaceae $(78.9 \%, 15$ species) and Hymenophyllaceae (75\%, three species).

Table 5. IUCN Red List status (at the European level) of ferns and lycopods by family.

\begin{tabular}{|c|c|c|c|c|c|c|c|c|c|}
\hline Family & Total & RE & CR & EN & VU & NT & LC & DD & $\begin{array}{l}\text { Best estimate of } \\
\% \text { threatened }^{*}\end{array}$ \\
\hline Aspleniaceae & 58 & 0 & $1(1.7 \%)$ & $2(3.4 \%)$ & $7(12.1 \%)$ & $10(17.2 \%)$ & $37(63.8 \%)$ & $1(1.7 \%)$ & 17.5 \\
\hline Cyatheaceae & 1 & 0 & 0 & 0 & 0 & $1(100 \%)$ & 0 & 0 & 0 \\
\hline Dennstaedtiaceae & 2 & 0 & 0 & 0 & 0 & 0 & $2(100 \%)$ & 0 & 0 \\
\hline Equisetaceae & 10 & 0 & 0 & 0 & 0 & 0 & $10(100 \%)$ & 0 & 0 \\
\hline Hymenophyllaceae & 4 & 0 & $1(25 \%)$ & 0 & 0 & 0 & $3(75 \%)$ & 0 & 25.0 \\
\hline Isoëtaceae & 20 & 0 & $4(20 \%)$ & $4(20 \%)$ & $2(10 \%)$ & $3(15 \%)$ & $6(30 \%)$ & $1(5 \%)$ & 52.6 \\
\hline Lycopodiaceae & 14 & 0 & 0 & 0 & $1(7.1 \%)$ & $5(35.7 \%)$ & $8(57.1 \%)$ & 0 & 7.1 \\
\hline Marsileaceae & 6 & 0 & 0 & $2(33.3 \%)$ & $2(33.3 \%)$ & $1(16.7 \%)$ & $1(16.7 \%)$ & 0 & 66.7 \\
\hline Ophioglossaceae & 11 & 0 & 0 & $1(9.1 \%)$ & $2(18.2 \%)$ & $1(9.1 \%)$ & $6(54.5 \%)$ & $1(9.1 \%)$ & 30.0 \\
\hline Osmundaceae & 1 & 0 & 0 & 0 & 0 & 0 & $1(100 \%)$ & 0 & 0 \\
\hline Polypodiaceae & 42 & $1(2.4 \%)$ & $3(7.1 \%)$ & $1(2.4 \%)$ & $2(4.8 \%)$ & $2(4.8 \%)$ & $30(71.4 \%)$ & $3(7.1 \%)$ & 15.8 \\
\hline Psilotaceae & 1 & 0 & $1(100 \%)$ & 0 & 0 & 0 & 0 & 0 & 100.0 \\
\hline Pteridaceae & 19 & 0 & 0 & $1(5.3 \%)$ & 0 & $2(10.5 \%)$ & $15(78.9 \%)$ & $1(5.3 \%)$ & 5.6 \\
\hline Salviniaceae & 1 & 0 & 0 & 0 & 0 & $1(100 \%)$ & 0 & 0 & 0 \\
\hline Selaginellaceae & 4 & 0 & 0 & 0 & 0 & 0 & $4(100 \%)$ & 0 & 0 \\
\hline Total & 194 & $\begin{array}{c}1 \\
(0.5 \%)\end{array}$ & $\begin{array}{c}10 \\
(5.2 \%)\end{array}$ & $\begin{array}{c}11 \\
(5.7 \%)\end{array}$ & $\begin{array}{c}16 \\
(8.2 \%)\end{array}$ & $\begin{array}{c}26 \\
(13.4 \%)\end{array}$ & $\begin{array}{c}123 \\
(63.4 \%) \\
\end{array}$ & $\begin{array}{c}7 \\
(3.6 \%)\end{array}$ & 19.9 \\
\hline
\end{tabular}

*The percentage of threatened species provides the mid-point figure as the best estimation of extinction risk. 


\section{The genus Dryopteris}

The European Dryopteris species are considered to be relatively well known for decades (Jalas and Suominen 1972). Worldwide, the genus Dryopteris is composed of 300 to 400 species (Fraser-Jenkins 1986, Wu et al. 2013), one of the largest genera in Polypodiaceae (Christenhusz and Chase 2014). The most recent Euro+Med PlantBase list includes 30 Dryopteris species (Christenhusz and von Raab-Straube 2013), of which 27 are found in Europe. These European Dryopteris were assessed as part of this project, together with Dryopteris ardechensis (which was erroneously omitted from the Euro+Med checklist).

Many species of Dryopteris are common in semi-shady to shady, boreal-temperate forests and some species extend up to the alpine belt to steep rocky slopes, while others extend into the subtropical laurisilva forests of Macaronesia. Soils on which these forest species grow are usually moderately moist and rich in organic matter. When found on alpine slopes they appear on rock cracks or in scree with little organic material. Many species generally show broad ecological amplitude regarding soil acidity although there are some species that are more abundant on slightly alkaline soils. These habitats are common in Europe and many species are thus generally not threatened here.

Genetically, the ploidy varies between taxa. Diploid species are generally not threatened; and most old allotetraploid species such as Dryopteris carthusiana, D. cristata, D. dilatata and D. filix-mas are widespread. More recently derived allotetraploid species, such as $D$. ardechensis, D. corleyi, D. crispifolia and D. tyrrhena, are often more restricted in their distribution range. Other species are rare in the north of Europe, like the pan-Arctic Dryopteris fragrans, whose range includes remote areas of the Ural Mountains and Kevo National Park in Finland, with stable and non threatened subpopulations. Some apomitic taxa, such as the members of the Dryopteris affinis complex, have benefitted from their ability to produce sporophytes asexually, allowing sporophyte production in drier environments and giving these an advantage over sexually reproducing diploid taxa in certain situations.

Further research and monitoring is needed on these species and the taxonomic issues of apomictic taxa need solving in order to identify the extinction risk of the Data Deficient Dryopteris taxa.
Fragrant Woodfern (Dryopteris fragrans) has a stable population trend and lack of major threats. It has been the subject of a monitoring programme at Kevo National Park, Finland. It has been assessed as Least Concern. (C) Henry Väre.

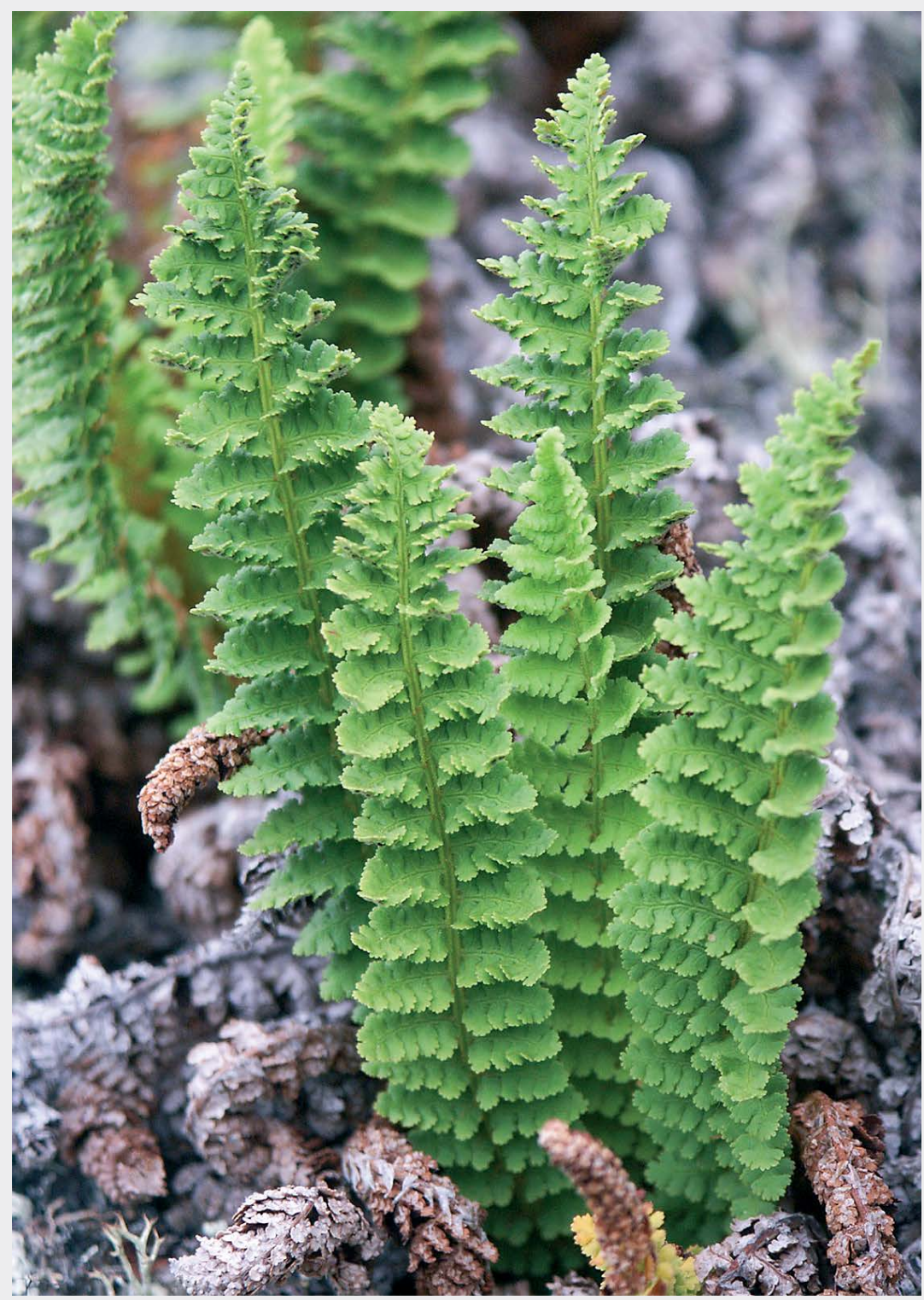




\subsection{Spatial distribution of species}

\subsubsection{Species richness}

The geographic distribution of fern and lycopod richness in Europe is shown in Figure 5 and is based on all native species with extant and possibly extant occurrence (191 species). The areas with the highest species richness include the Macaronesian islands, Corsica and several mountainous areas in Europe such as the Alps, the Pyrenees, the Massif Central and the Carpathians. Species richness gradually declines towards Russia and southern Mediterranean Europe.

Figure 5. Species richness of European ferns and lycopods.

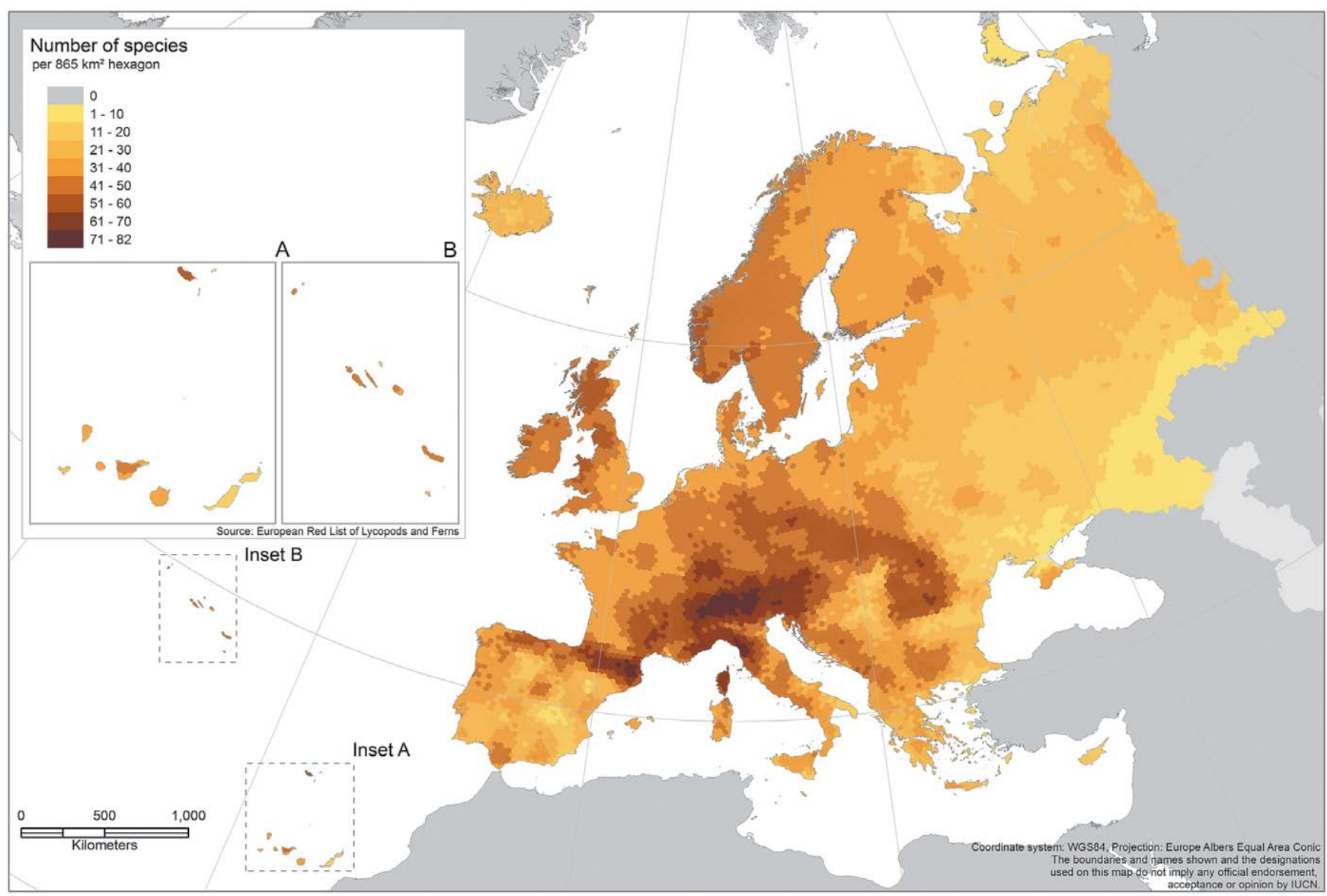

\subsubsection{Endemic species richness}

In Figure 6, the richness of endemic fern and lycopod species in Europe is shown based on the presence of 52 species. Lycopods and ferns show high levels of endemism in the Azores, Madeira and the Canary Islands. This highlights the role of the Macaronesian islands as endemic hotspots due to their isolation and distinct environmental conditions, particularly the laurisilva forests and the high elevation heathlands. The Macaronesian archipelago has a milder, more humid climate and contains species that arrived from Europe, Africa and through prevailing western winds from tropical America. The island habitats and the patchy nature of the laurisilva forests typical of the wetter zones of these islands, isolate populations and allow them to evolve in different ways, resulting in high endemism.

There is also some concentration of endemic species in and around the Alps, due to elevational diversity and soil gradients - in common with Bilz et al. (2011) and Allen et al. (2014) - in northern Sardinia, locally in mainland Italy and in southern Spain. 
Figure 6. Distribution of endemic lycopods and ferns in Europe.

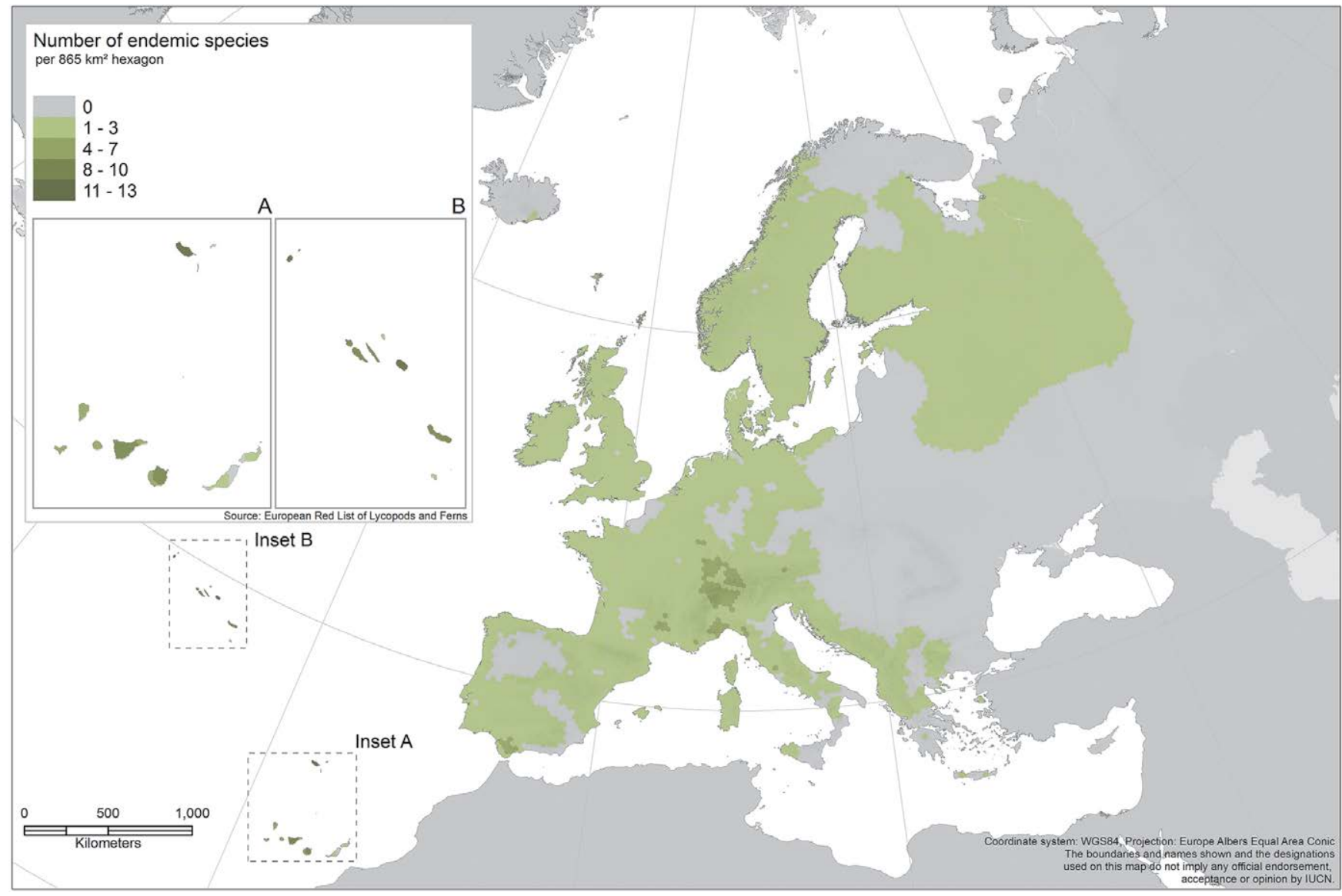

\subsubsection{Distribution of threatened species}

In Figure 7 , the richness pattern of threatened ferns and lycopods in Europe, which considers 36 threatened species, is illustrated showing the greatest concentration in Madeira and the Azores (particularly the islands of Flores, Pico, São Jorge and Terceira), followed by the Swiss Alps. This pattern reflects the endemic richness distribution explained above. Many of these species are threatened due to their restricted geographical range and/or small population sizes, with fragile and degraded habitats like the montane juniper forest or crater lakes in the Azores (e.g., Grammitis spp., Elaphoglossum semicylindricum, Isoëtes azorica) and lower elevation laurisilva forest vegetation more widely in the Macaronesian region (e.g.,
Arachniodes webbiana, Asplenium auritum, A. anceps, Polystichum drepanum).

The lack of threatened species in central Europe can be explained by the fact that most species found in these areas are rather widespread, having large ranges that extend over much of Europe. Ferns are usually wind-dispersed and thus many species occur over wide geographical ranges, with most species being rather widespread across the Northern Hemisphere. In addition to the strict endemic species, some are restricted to western Europe, but may have a few populations in northern Africa, which has a similar climate and proximity, and are thus not considered endemic to Europe. However, some of these may be threatened at the EU 28 level. 
Figure 7. Distribution of threatened lycopods and ferns in Europe.

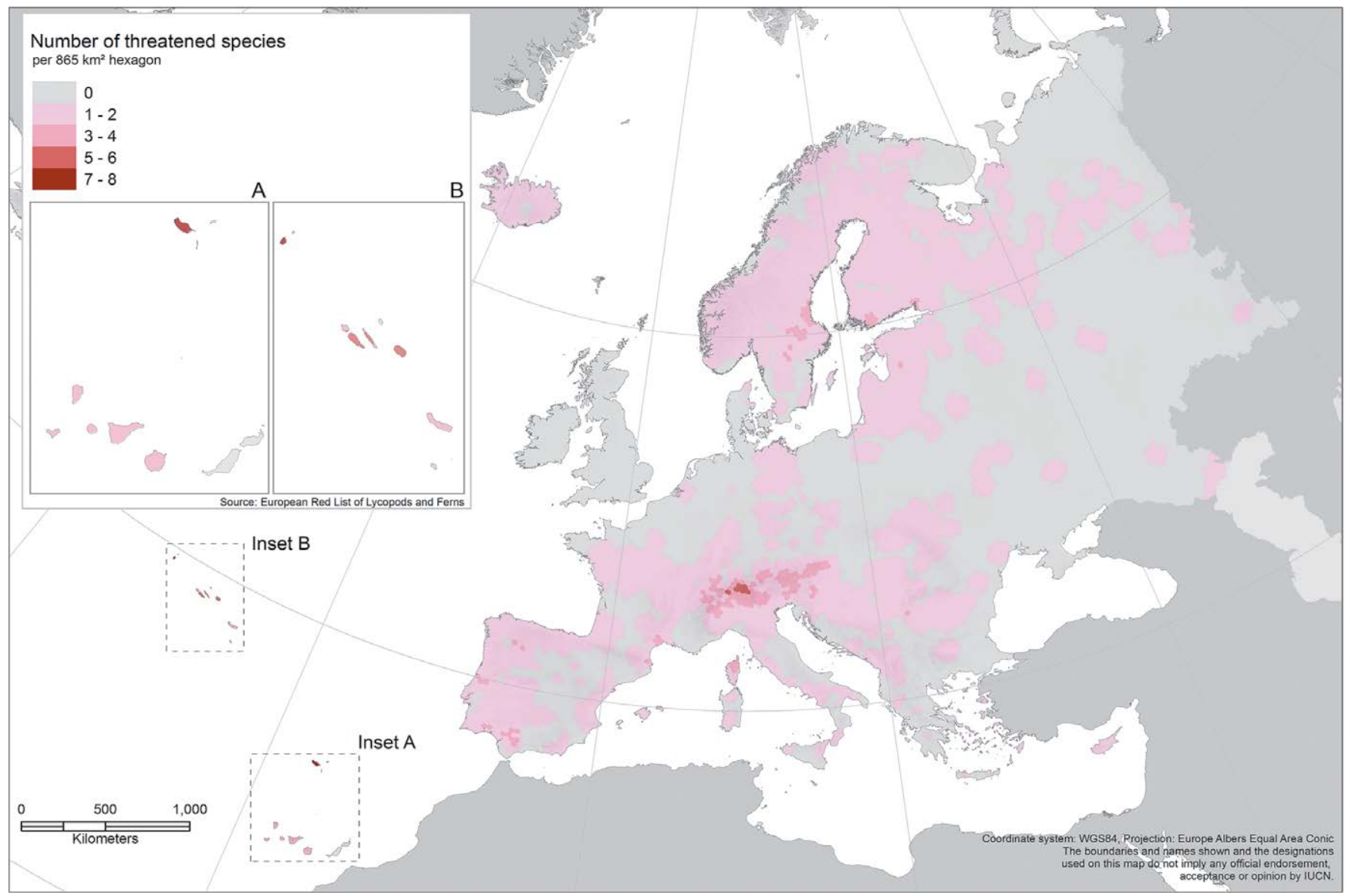

Figure 8. Distribution of Data Deficient lycopods and ferns in Europe.

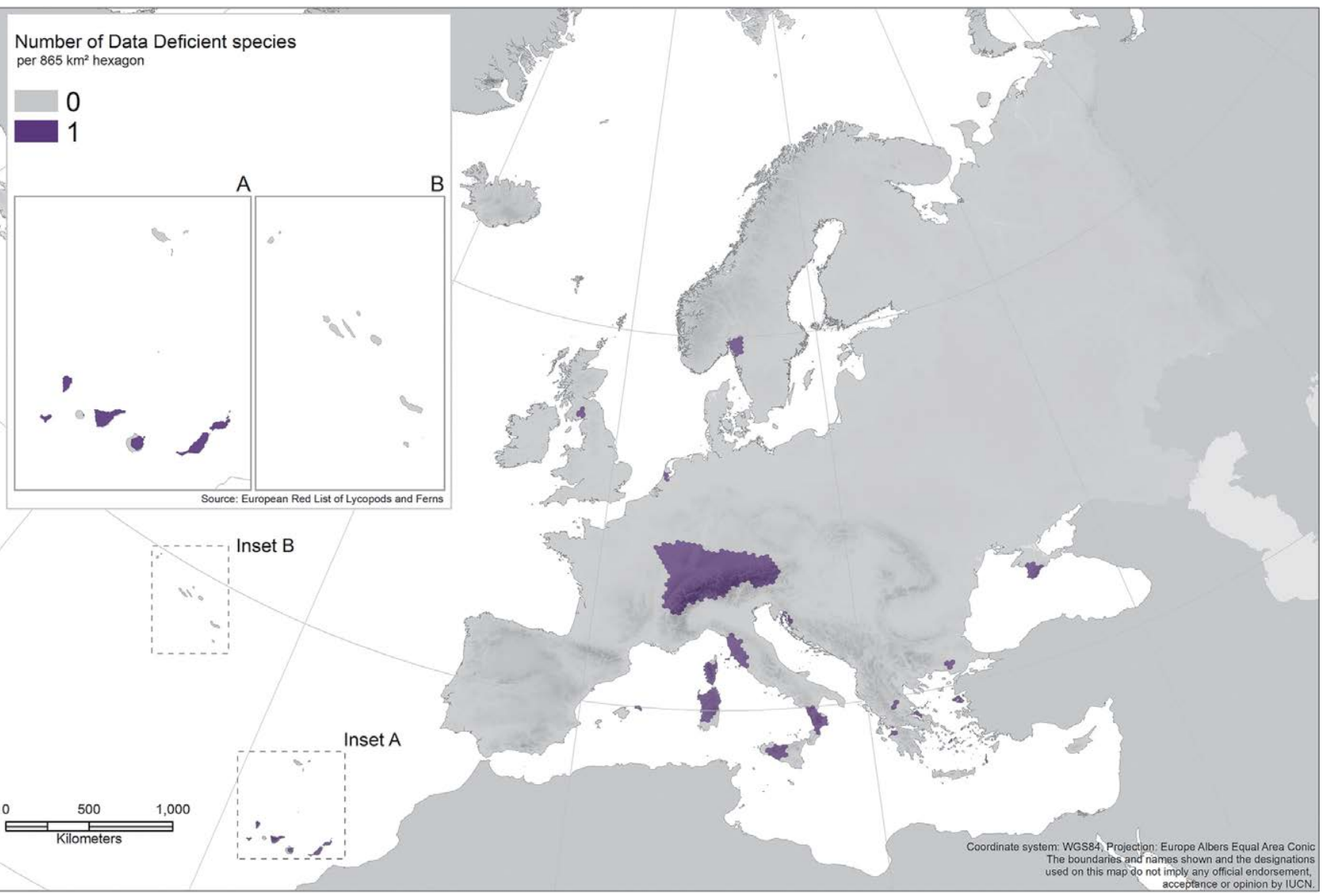




\subsubsection{Distribution of Data Deficient species}

In Figure 8, the richness of Data Deficient (DD) species is presented based on seven DD species. Two of these species are endemic to Europe. DD species are present in and around the Alps, Croatia, Crimea, Greece, Italy (including Sicily and Sardinia), France (including Corsica), the Canary Islands, Scandinavia and northern UK.

Some species are listed as DD because they have been recently described and there is no information to elucidate their trends, while others have been assessed as DD due to taxonomic uncertainty and the difficulty to differentiate between different species unless studied genetically.

\subsection{Major threats to lycopod and fern species in Europe}

A fully comprehensive overview of the threats to ferns and lycopods in Europe is not yet possible because the threats to some species remain unknown. However, conservation and management must move forward in spite of our current data gaps, particularly in relation to taxonomic uncertainty and lack of quantitative species-specific population trends.

An overview of the major threats to the majority of the species is available since the threats remain unknown for only 21 species. According to the European Red List, 39 species have no identified threats. Threats identified for the remaining species (134) are presented below, and a summary of the relative importance of the different threatening processes is shown in Figure 9.

\section{Urbanisation and infrastructure}

A total of 58 species are affected by urbanisation and infrastructure, including 24 threatened species. This includes the building of tourist, recreational, residential, commercial and industrial areas and infrastructure, affecting species like Lycopodium annotinum. Furthermore, 24 of these species are affected by the construction of roads and railroads, including 14 threatened species. These species are directly affected by the destruction of their substrate and the fragmentation and reduction of their habitats. Other species growing on historic dry stone walls in Macaronesia and the UK may be threatened by the destruction of these walls for widening of roads and the creation of new paths, both inside and outside reserves.

\section{Human intrusion and disturbance}

A total of 45 species are affected by human intrusion and disturbances, including 16 threatened species. This includes intrusions and recreational activities such as rock climbing and canyoneering, where species on rock faces and ledges may be selectively removed or inadvertently displaced. The filmy-ferns (Hymenophyllaceae) may be at particular risk from scrambling activities in sheltered river gorges with waterfalls - when dislodged, these fragile ferns will inevitably die.

Figure 9. Major threats to lycopods and ferns in Europe.

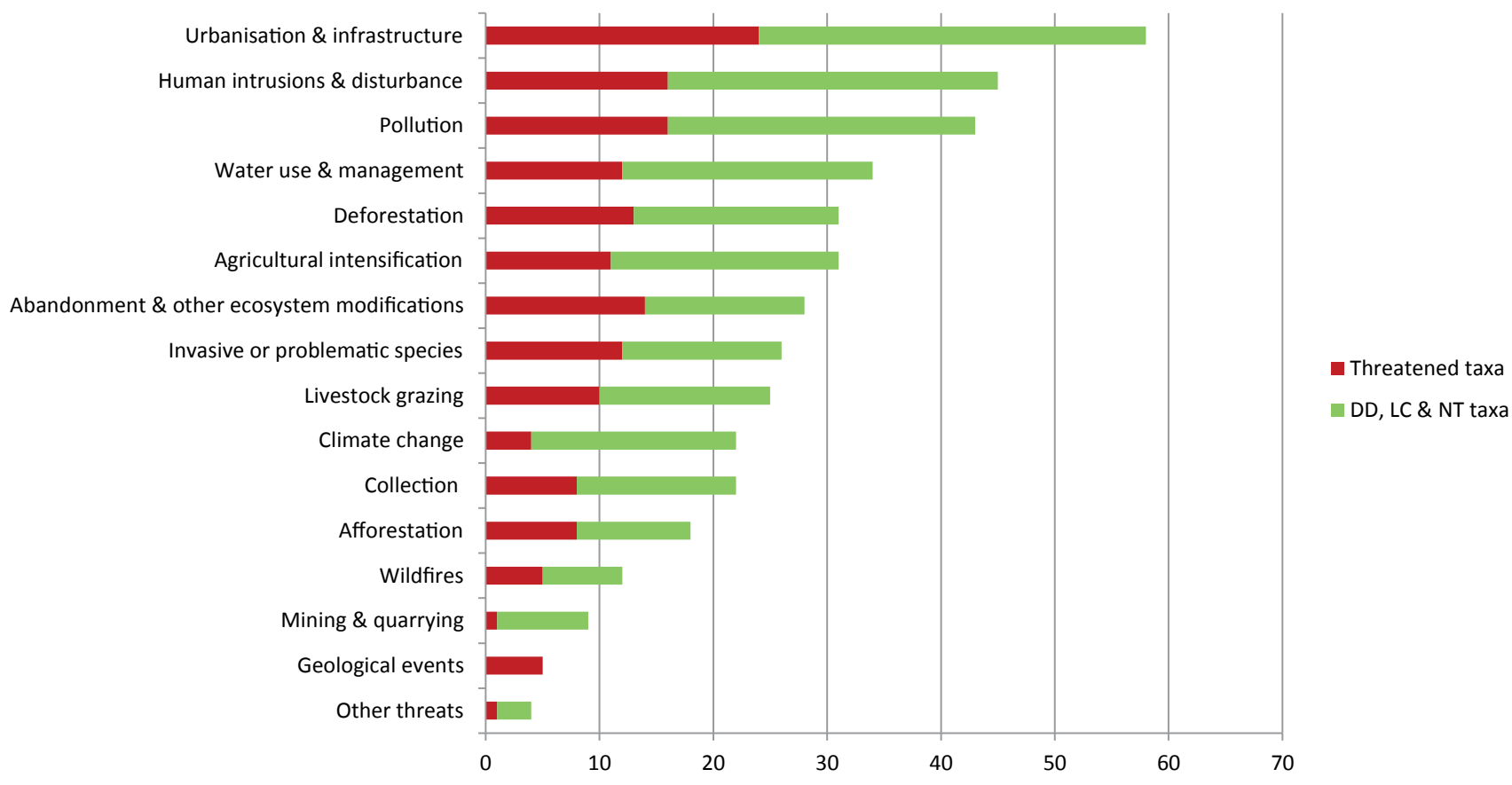


Saxicolous species colonising urban masonry are of particular concern, as they are often locally rare and threatened by restoration and re-development projects. Old masonry and dry stone walls are often last refuges for some of the locally rarer fern species. In addition, vernal pools are also under threat by intrusion and trampling, particularly during the dry season when the pools have no water and the plants, including threatened Isoëtes species, are dormant.

\section{Pollution}

A total of 43 species are affected by pollution, including 16 threatened species. Species are usually affected by domestic and urban waste water, industrial, forestry and agricultural effluents (including fertilisers, herbicides and pesticides). As a result, many terrestrial and aquatic ecosystems suffer from eutrophication and these species are therefore outcompeted by other invasive alien or native species. This is especially significant for aquatic species, such as Thelypteris palustris, where eutrophication can cause algal blooms, smothering the slower growing eutrophic plants. Some species are also affected by airborne pollution and others by rubbish and solid waste.

\section{Water use and management}

A total of 34 species are affected by water use and management, including 12 threatened species. Drainage and consequent changes in hydrological regime, as well as the construction of dams have strong effects especially on aquatic or water-dependant species (e.g., Lycopodiella inundata, Marsilea spp.).

\section{Deforestation}

Deforestation poses a major threat to species as the forest cover needed for many fern species to thrive is removed. If the area is completely clear-cut, local populations are likely to become extinct. For instance, the Regionally Extinct Grammitis quaerenda is thought to have disappeared as a result of deforestation, in conjunction with other threats. A total of 31 species are affected by deforestation, including 13 threatened species. Compared to clear felling, selective logging may offer the change for ferns and lycopods to maintain their habitat or local ecosystems and increase their change of survival.

\section{Agricultural intensification}

A total of 31 species are affected by agriculture, through annual and perennial non-timber crops, including 11 threatened species. This is due to the intensification of agriculture through the use of heavy machinery and changes in the land use, among others. An example of a species affected by agricultural intensification is Botrychium boreale.

Marsh Clubmoss (Lycopodiella inundata) is widespread and locally abundant, however a significant number of local declines have been reported. It has been assessed as Least Concern. (C) Fred Rumsey.

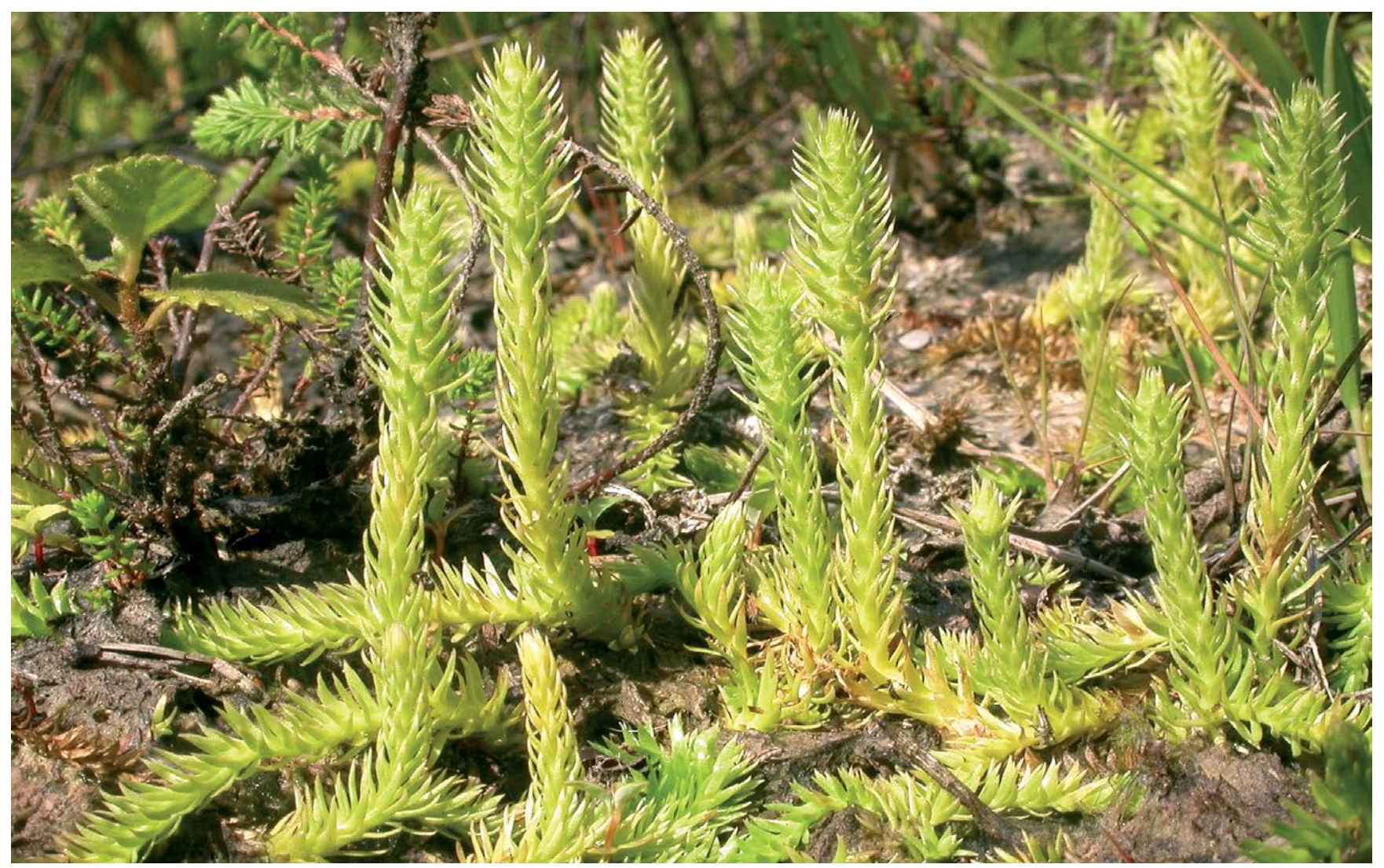




\section{Land abandonment and other ecosystem modifications}

A total of 28 species are affected by abandonment and other ecosystem modifications, including 14 threatened species. Most of these species are affected by the abandonment of certain areas, which leads to encroachment and succession of vegetation and can ultimately outcompete some species. Some habitats in Europe are dependent on management since most are ultimately created by an interaction between nature and human activities. An example is Isoëtes malinverniana, which is in part reliant on the traditional maintenance of ancient rice field irrigation canals in northern Italy. The abandonment of extensive grazing by cattle in boreal forests appears to result in the disappearance of many species of Botrychium from former sites, as moonworts are dependent on slight disturbance and open patches in these otherwise canopy-closed coniferous forests.

\section{Invasive or problematic species}

A total of 26 species are affected by invasive or problematic species, including 12 threatened species. The effects of invasive species are particularly obvious in certain areas like the Macaronesian islands (Silva et al. 2009), where invasive trees cause adverse conditions for endemic fern species to grow. For example, Pilularia globulifera is threatened by the exotic invasives Crassula helmsii and Myriophyllum aquaticum in the UK and Ireland. In addition, species can also be outcompeted by other native species that can have negative effects on them as a result of succession and other environmental changes, including eutrophication and land abandonment.

\section{Livestock grazing}

A total of 25 species have been identified to be affected by livestock grazing and ranching, including 10 threatened species. Grazing, particularly by goats and sheep, can be detrimental for rock-dwelling evergreen fern and lycopod species. An example of a species affected by grazing is Ophioglossum azoricum, whose fronds are usually eaten by cattle in the Azores.

\section{Climate change}

Climate change has been identified as a threat for 22 species, including four threatened species. There are current, potential and future effects as a result of climate change, which include temperature extremes, droughts, habitat shifting and alteration, storms and flooding, among other impacts. Species in northern environments and high elevations are significantly more prone to experience the effects of climate change. For instance, Athyrium distentifolium (and particularly the ecotype referred to Athyrium distentifolium var. flexile, which is endemic to Scotland) is reliant on snow-beds and areas

Piedmont Quillwort (Isoëtes malinverniana) is endemic to the Piedmont and western Lombardy in northern Italy and it has declined by more than $80 \%$ in the last 30 years. It has been assessed as Critically Endangered. (C) Thomas Abeli.

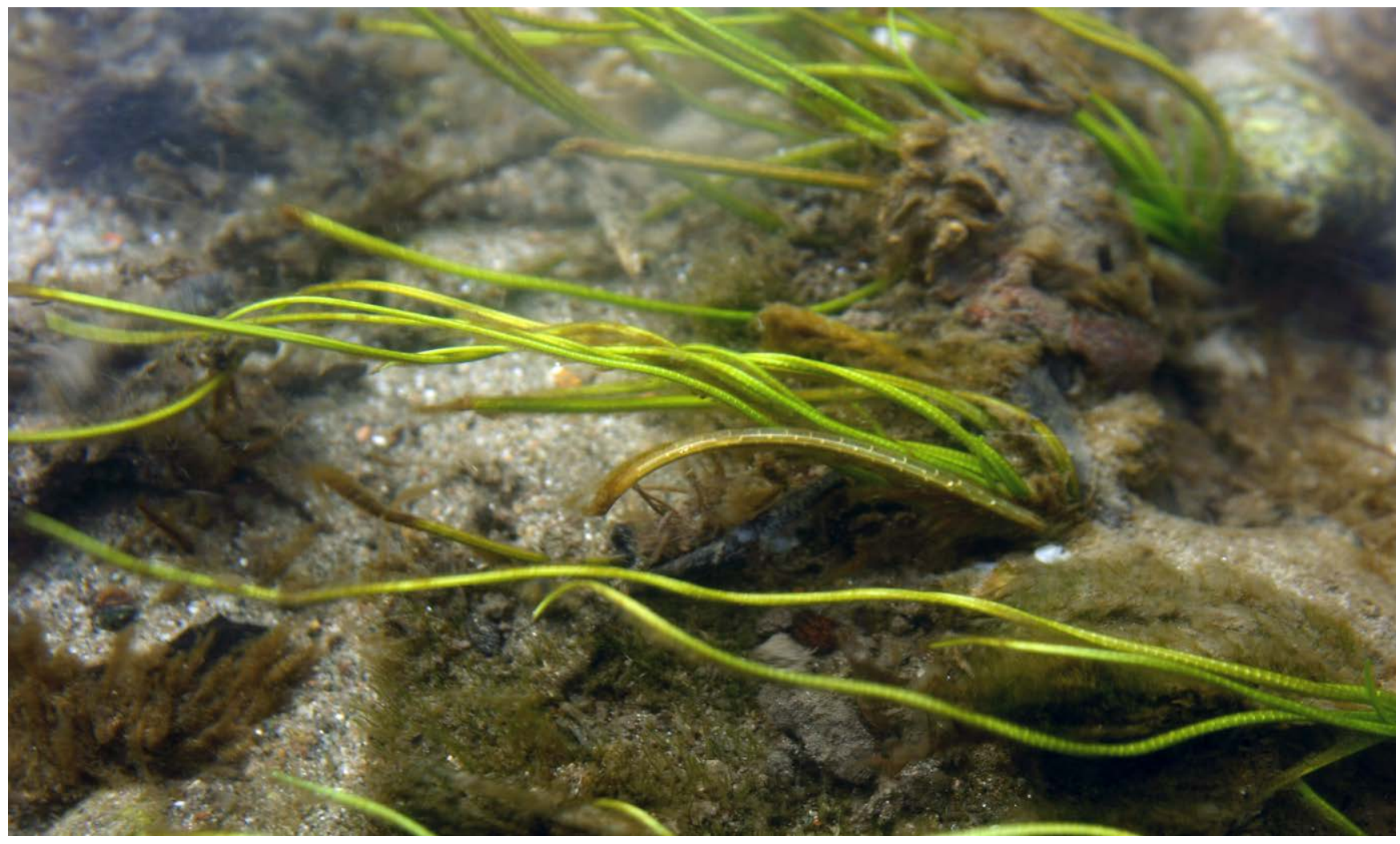


Small Adder's-tongue (Ophioglossum azoricum) is an Atlantic-Mediterranean species that in Europe is found on mostly inaccessible localities, although it can be locally threatened by grazing. It has been assessed as Least Concern. (C) Fred Rumsey.

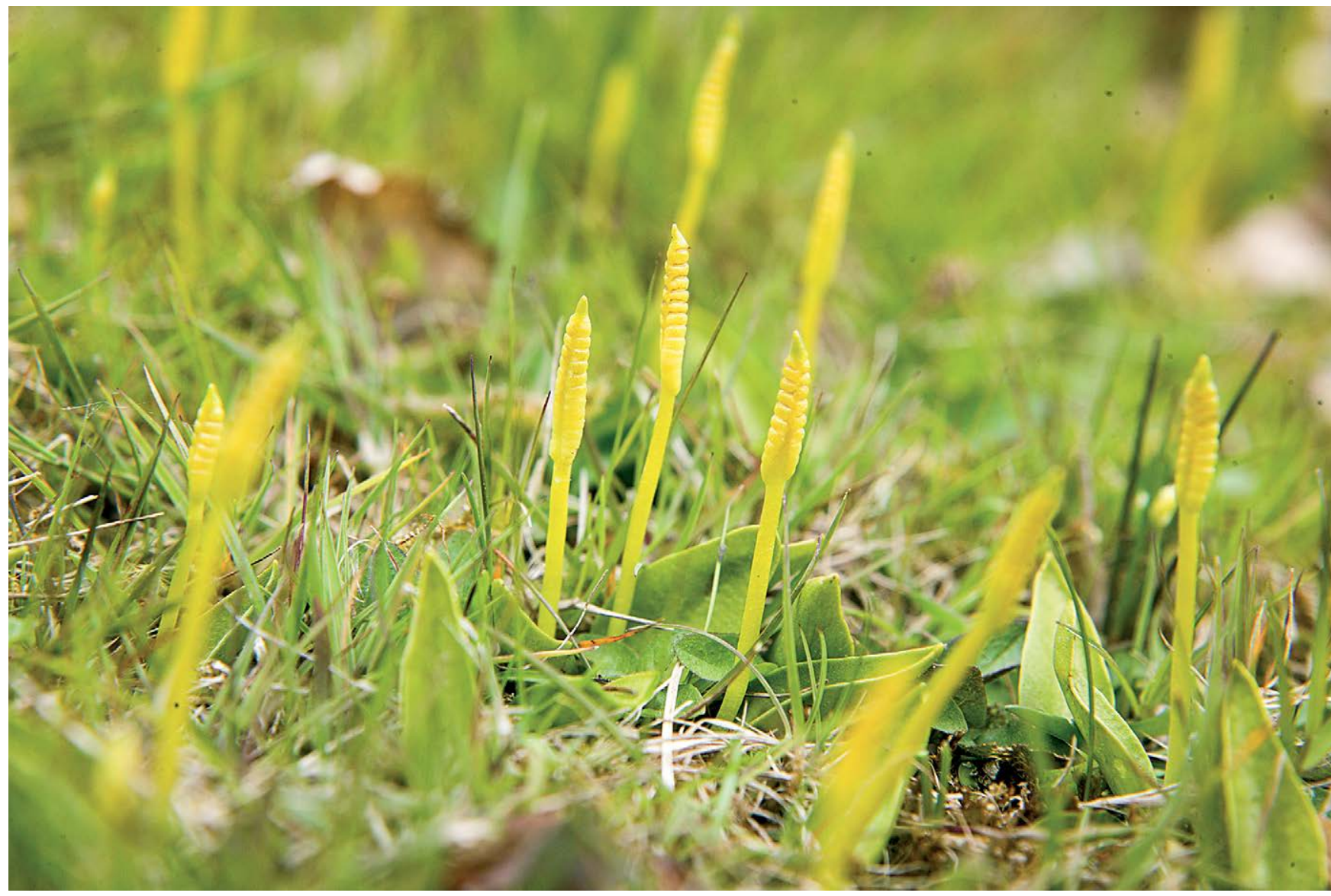

of late snow-lie, which have been lost or much reduced as winters have become milder (McHaffie 2005). On the other spectrum, species from low-lying steppe vegetation such as Marsilea strigosa may suffer from extreme droughts and unseasonal heat waves.

\section{Collection}

A total of 22 species are affected by targeted collection, including eight threatened species. Ferns and lycopods have historically been affected by collection for horticultural purposes and for herbaria (Whittingham 2012). This threat continues, particularly for the most localised and rare species, such as Grammitis azorica and G. jungermannioides in the Azores. Pteridomania still persists and while collecting wild specimens for private herbaria or ferneries is still desirable to some people, it can be devastating for rare and localised species. Some species have suffered from collection for their unsubstantiated but perceived medicinal values, like Elaphoglossum semicylindricum in Madeira. Many rare native ferns are now available in the horticultural trade.

\section{Afforestation}

18 species are affected by changes in land use as a result of wood and pulp plantations, including small holder and agro-industry plantations. This includes eight threatened species. An example of a species affected by afforestation is Dryopteris corleyi. Plantation forests are usually dense and pose unsuitable conditions for most fern species to thrive in, although some ferns are more likely to hang on in these habitats than other vascular plants.

\section{Other threats}

A total of 12 species (including five threatened species) are affected by wildfires, such as Psilotum nudum. In most cases they are threatened by an increase in fire frequency. Nine species (including one threatened species) are affected by mining and quarrying, like Paragymnopteris marantae, even if some taxa can find suitable habitats in abandoned quarries. Finally, five threatened species, including Polystichum drepanum, may be affected by geological events (mainly avalanches and landslides). Four more species (including one threatened species) have been identified with isolated additional threats, including aquaculture. 
Scaly tongue-fern (Elaphoglossum semicylindricum) is an epiphyte species endemic to the Azores and Madeira (Portugal). It is affected by cattle trampling, goat grazing, the cutting of trees, collection and wildfires. It has been assessed as Endangered. (C) Fred Rumsey.

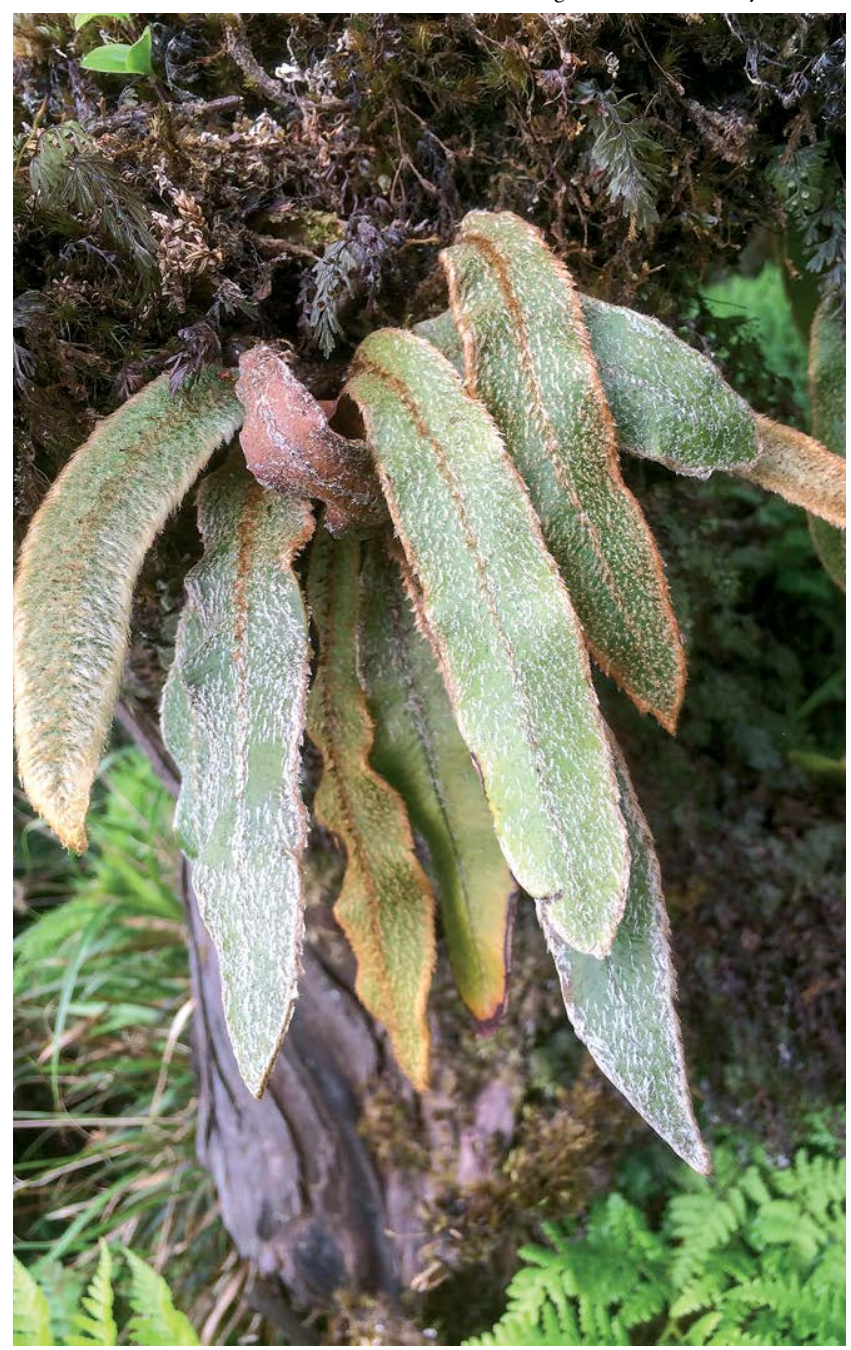

\subsection{Population trends}

Documenting the population trend of a species provides key information when assessing its Red List status. As part of this process, the overall populations of the species were assessed as declining, stable, increasing or unknown.

Overall, $21.2 \%$ (41 species) of lycopod and fern species in Europe are thought to be in decline, including 60.9\% of threatened species ( 25 species). The majority of species (63.7\%; 123 species) are considered to be stable, including $4.9 \%$ of threatened species (six species), and $2.6 \%$ (five species) are increasing (Figure 11), all of which are LC. However, $12.4 \%$ of species (24 species) have unknown population trends, with six threatened species.
Figure 11. Population trends of European lycopods and ferns.

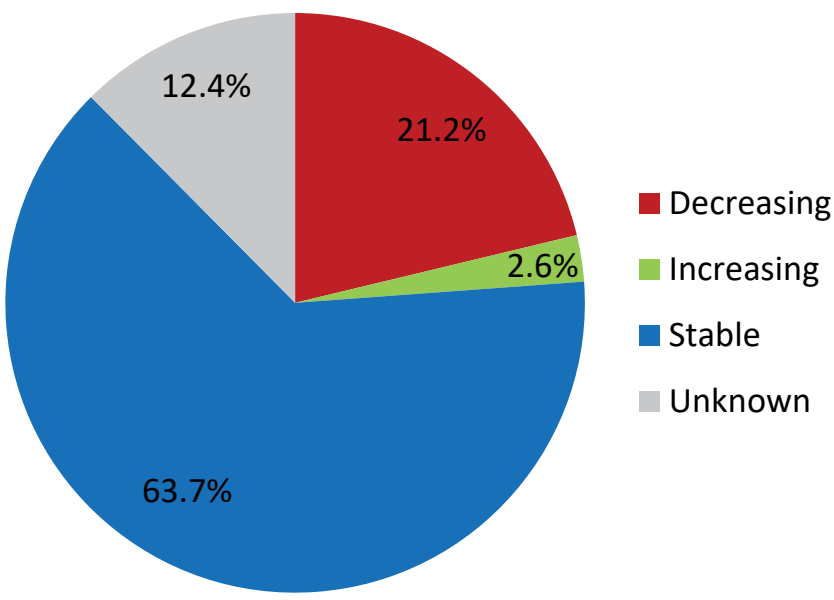

\subsection{Gaps in knowledge}

While there was not enough information to assign a Red List Category to seven species (and therefore they were considered as Data Deficient), there are some knowledge gaps that should be addressed. There is considerable taxonomic uncertainty regarding certain groups of species (particularly in the genera Asplenium, Dryopteris and Isoëtes). Furthermore, some species have been recently described and thus there is no information available on the population size and trend of the species as a result of the lack of monitoring, absence of historical data or impracticality of individual counts in clonal species. Likewise, some species are considered to be "possibly extinct", and further surveys and expeditions should be undertaken in order to confirm whether the species is still extant. This is particularly relevant to species that have irregular emergence or ephemeral appearance and are therefore difficult to monitor.

In addition, there is a lack of expertise on these species across Europe and the establishment of an expert network to facilitate information exchange would certainly improve the knowledge of population sizes, population trends and threats to these species throughout their European range. The population size of a number of species remains difficult to elucidate and further research and monitoring measures should be strategically put in place. 


\section{Fern fever}

In Victorian Britain, the countryside attracted an increasing number of amateur botanists, particularly because the more remote areas became more accessible through improved and new roads and railways. Starting around the late 1830s, people botanised around the wetter western and northern parts of Britain collecting plants and publishing their findings in local botanical journals. Ferns and lycopods were of particular interest as they were more abundant in the remote parts of Britain and less studied than flowering plants. Fern collecting drew enthusiasm across social classes, and this common interest brought together people of different backgrounds. Leaves were collected and pressed in albums to be displayed at home, but live plants were also popular and many rare plants were collected to be grown in gardens and in glass ferneries, some to the brink of extinction. Particularly hard-hit were Woodsia ilvensis and W. alpina, both nearly collected to extinction in the UK and now among the rarest plants in Britain. The humidity-loving Killarney fern (Trichomanes radicans) was already rare in Victorian times and is only now starting to recover in some populations.

For some, fern collecting was a fashionable hobby, for others a more serious scientific endeavour, but soon the entire nation became fern crazy and the terms 'pteridomania' or 'fern fever' were coined in the popular press. Pteridomania also became commercialised as Victorian decorative arts adopted fern motifs on pottery, glass, metal, textiles, wood carvings, sculptures, letter paper and even grave stones. Specialist books to identify ferns were popular and nurseries specialising in native and exotic ferns supplied many plants that could be grown in gardens or greenhouses. Very common were the Wardian cases, a type of small glass boxes in a wooden frame, in which the humidity could be regulated, and which were originally used to transport living plants on long sea journeys. These Wardian cases (forerunners of the terrarium) also protected the ferns from the London air pollution and soon became stylish features of drawing rooms. This fashion started in England but it was soon exported to North America, continental Europe and even as far as Australia and New Zealand, which helped spread the fern craze further afield.

Ferneries (cool humid greenhouses specialised for ferns) are maybe a fashion of the past, but there is still a lively interest in ferns among gardeners and nurseries. Some exotic fern species are cultivated at such large scale in Europe that they are now naturalising, a particularly surprising case being the Australian tree fern (Dicksonia antarctica), which has found suitable habitats in the Azores, western Britain and Ireland - the former stomping grounds of the Victorian pteridomaniacs - freely establishing itself from spores. The Victorians surely would have been fascinated by this exotic newcomer and probably would have encouraged its spread.

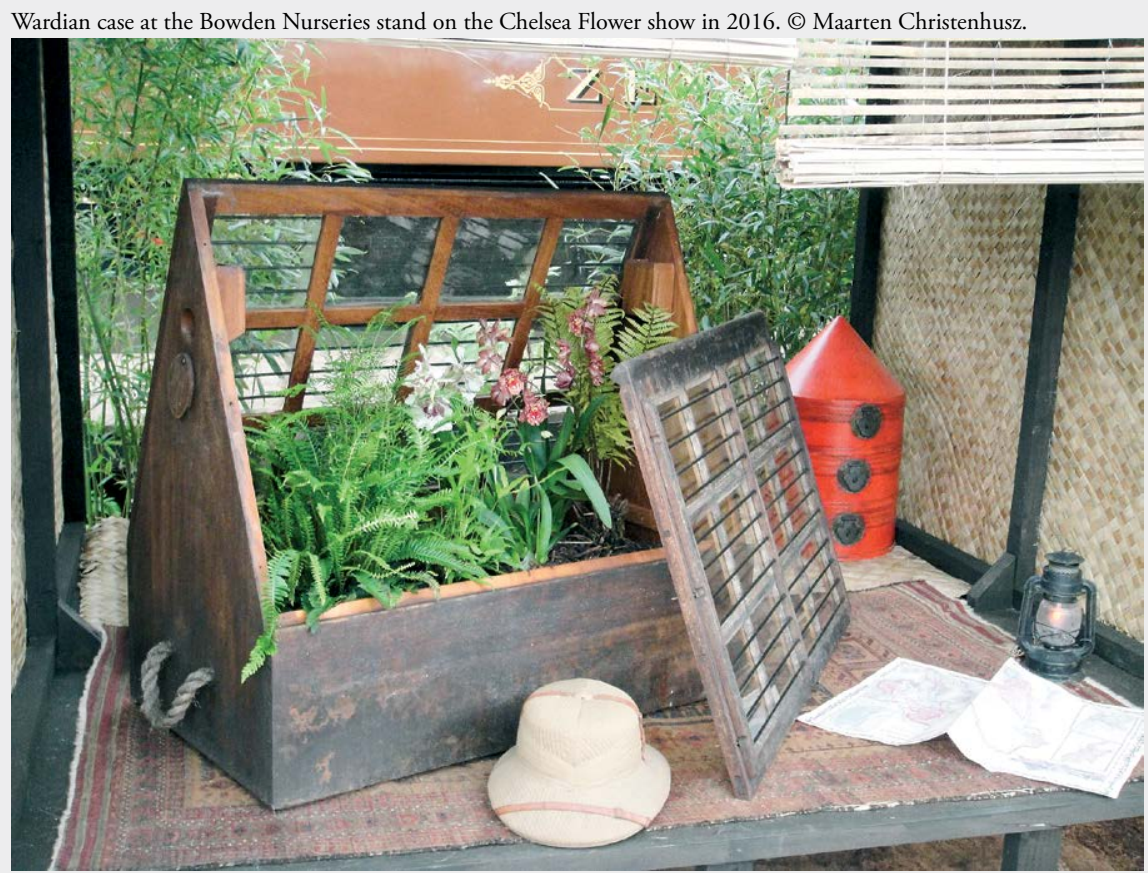




\section{Conservation measures}

\subsection{Conservation of lycopod and fern species in Europe}

European countries and EU Member States are signatories to a number of important conventions aimed at conserving biodiversity, including the 1979 Bern Convention on the Conservation of European Wildlife and Natural Habitats, and the 1992 Convention on Biological Diversity (CBD). Through the CBD, the Strategic Plan 2011-2020 was established, which includes 20 targets (Aichi Targets) that guide the implementation of the CBD and all the other biodiversity conventions. In particular, Target 12 focuses on preventing the extinction of known threatened species and improving their status (CBD 2011). The outcomes of this Red List project certainly help to measure the progress made towards meeting these targets, especially because some species have been re-assessed and this can contribute to measure the trends on the status of these species.

The Global Strategy for Plant Conservation (GSPC) was adopted by the CBD at the 2002 Conference of the Parties and updated at the $10^{\text {th }}$ Conference of the Parties (CBD 2010a). In order to coordinate the implementation of the GSPC at the regional level, the

Water Horsetail (Equisetum fluviatile) is widespread across Europe. It has a clonal nature and it often forms large stands. It has been assessed as Least Concern. (C) Maarten Christenhusz.

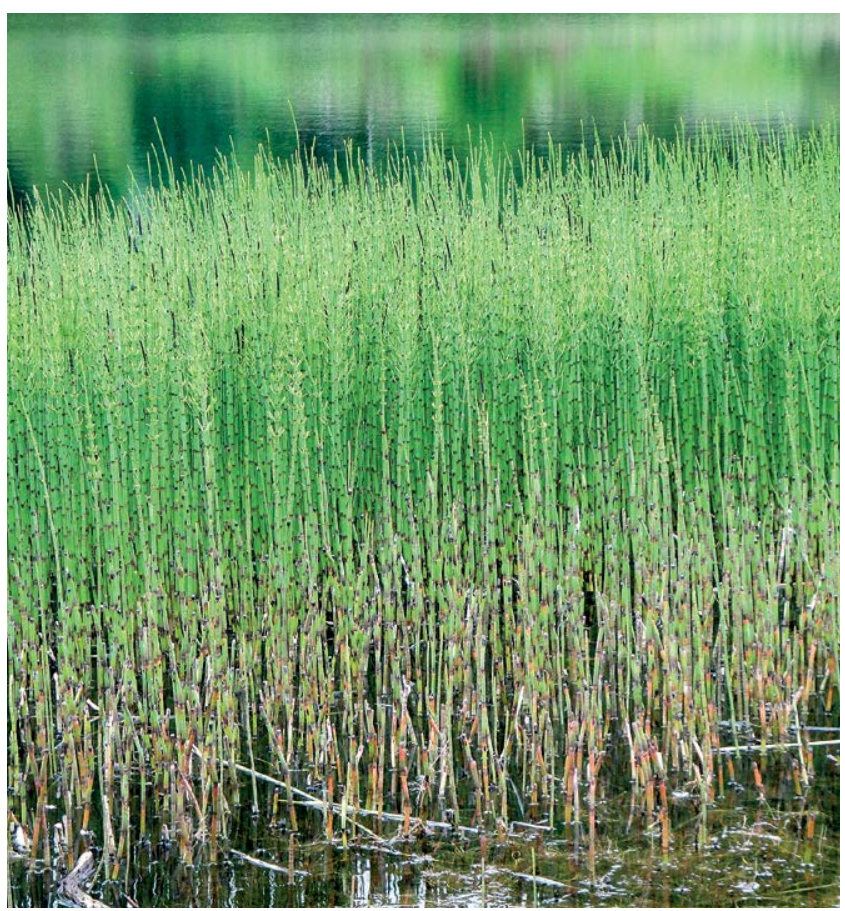

European Strategy for Plant Conservation (ESPC) was adopted. In particular, Target 2 (calling for an assessment of the conservation status of plant species), Target 5 (through the identification of Important Plant Areas), Target 7 (in situ conservation), Target 8 (ex situ conservation), Target 12 (preventing the extinction of known threatened species and improving their status), Target 13 (sustainable practices associated with plant use) and Target 14 (awareness raising) (CBD 2011) are relevant for the conservation of ferns and lycopods.

The Bern Convention is a binding international legal instrument that aims to conserve wild flora and fauna and their natural habitats and promote European cooperation towards that objective. It covers all European countries and some African states. In Appendix I of the Bern Convention (Strictly Protected Flora Species), a total of 23 fern and lycopod species are listed. In addition, at the pan-European level, European countries across the continent endorsed the Pan-European 2020 Strategy for Biodiversity (UNEP 2011), which re-focuses efforts to prevent further loss of biodiversity in the pan-European region. It also provides a European mechanism for supporting the implementation of the global Strategic Plan for Biodiversity. No native European fern or lycopod species are listed on the Annexes

Wood Horsetail (Equisetum sylvaticum) is a widespread species that can be weedy and invade agricultral land in some areas. It has been assessed as Least Concern. (C) Fred Rumsey.

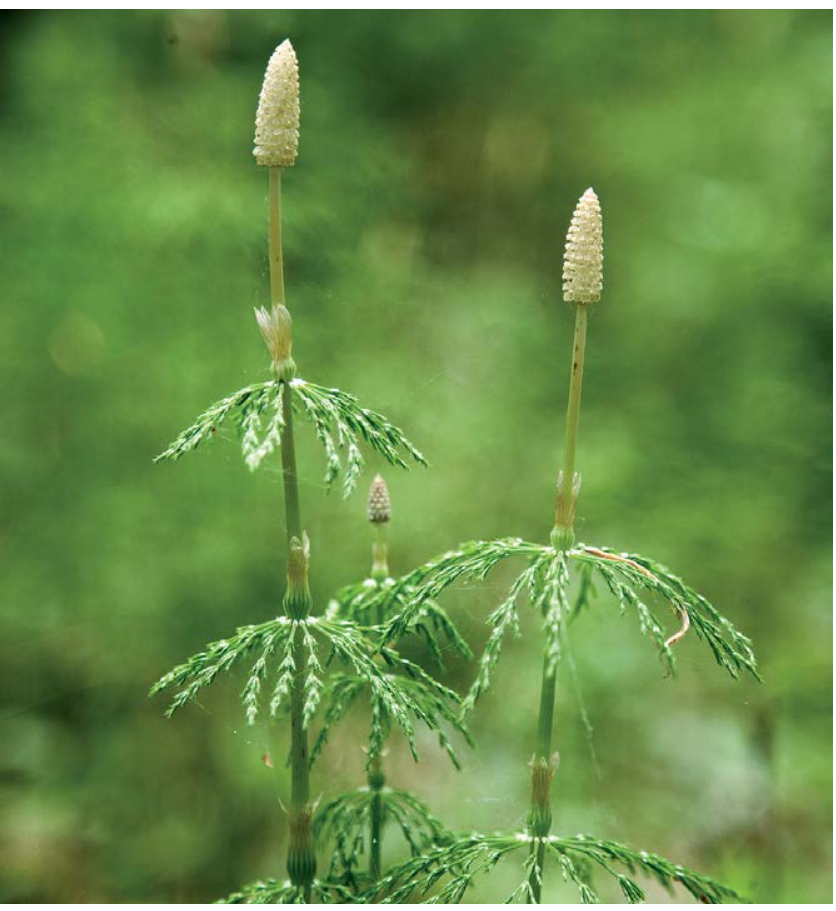




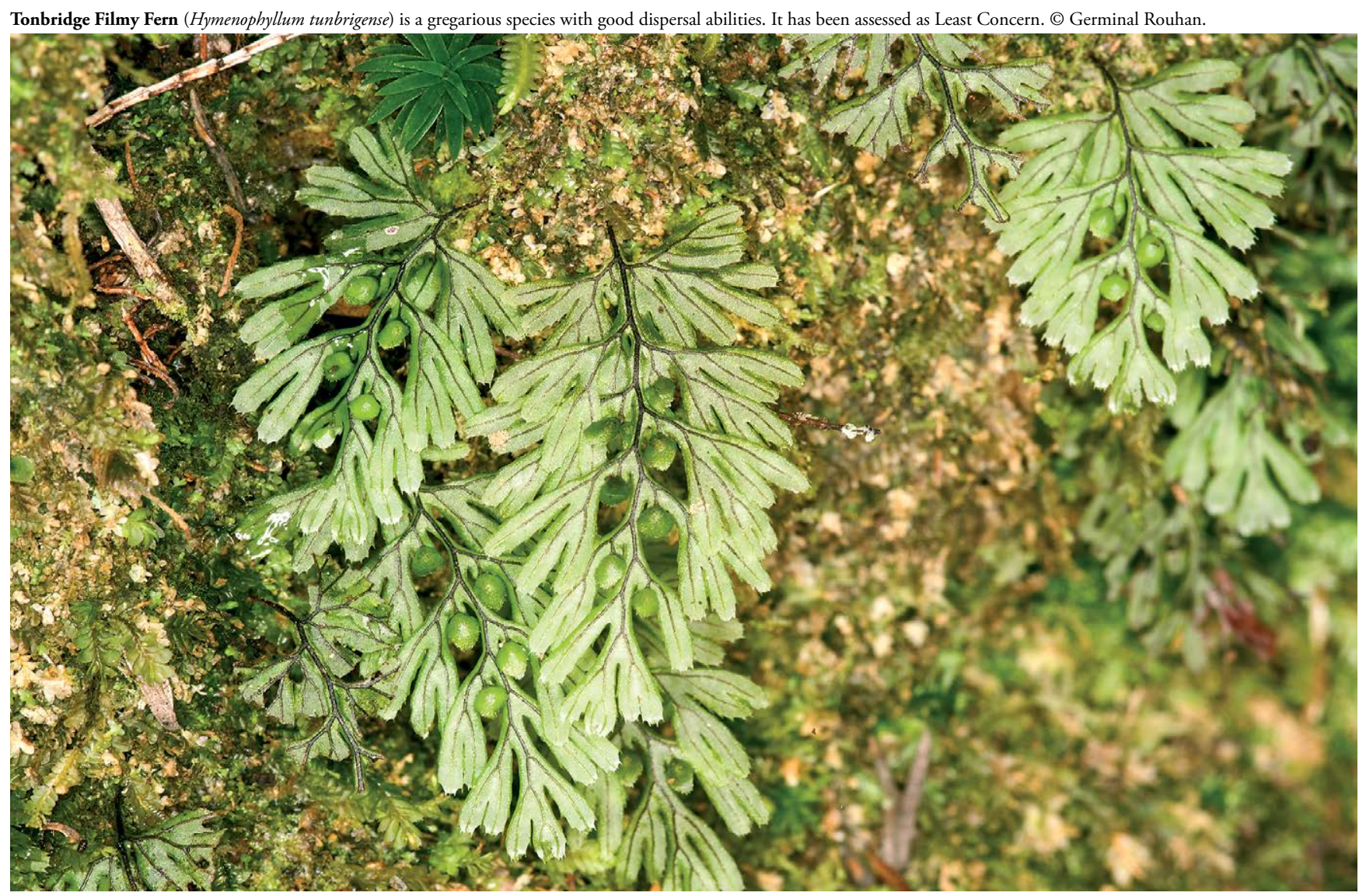

of the Convention of International Trade in Endangered Species of Flora and Fauna (CITES), although some nonnative tree ferns that have become naturalised in Europe (e.g., Cyathea or Dicksonia species) are included.

The nature conservation policy of the European Union is based on two main pieces of EU legislation - the 1979 Birds Directive and the 1992 Habitats Directive (jointly referred to as the Nature Directives). Of the 191 fern and lycopod species present in the EU 28, 23\% are endemic to the EU 28, highlighting the conservation responsibility of the EU towards these species, even though only 12 species are listed in Annex II and 13 in Annex IV. All Lycopodium species are listed in Annex V. Furthermore, there are some habitats listed in Annex I where Isoëtes species occur, such as: Oligotrophic waters containing very few minerals of Atlantic sandy plains with amphibious vegetation: Lobelia, Littorella and Isoëtes; Oligotrophic waters containing very few minerals of West Mediterranean sandy plains with Isoëtes; or Oligotrophic waters in medio-European and perialpine area with amphibious vegetation: Littorella or Isoëtes or annual vegetation on exposed banks (Nanocyperetalia). In addition, certain habitats listed in the Habitats Directive are particularly rich in endemic fern species, such as the Macaronesian Juniperus woods (a habitat sub-class under the general "Mediterranean and Macaronesian mountainous coniferous forests" definition).
One of the main tools to enhance and maintain biodiversity in Europe is the Natura 2000 network of protected areas, which currently consists of over 27,000 sites, covering almost a fifth of the EU land and marine area (EC 2016). Natura 2000 sites provide an essential tool in conservation even if the sites were not specifically designated for the preservation of particular fern or lycopod species (there are 12 species listed in Annex II of the Habitats Directive).

The EU Water Framework Directive, adopted in 2000 and aimed at protecting European waters, can also be relevant for aquatic and water-dependant fern and lycopod species. A good ecological status of surface waters has positive effects on ecosystem function as a habitat for plants (Janauer et al. 2015).

The results of the Red List assessment indicate that 86.5\% of threatened species (32 species) were recorded in at least one protected area (including national parks, Natura 2000 sites or nature reserves). However, the management of protected areas rarely focuses on threatened lycopods and ferns. One of the few examples, focused on Isoettes setacea, can be found in Rhazi et al. (2004). Additionally, Dryopteris fragrans was monitored for decades in Kevo National Park, northern Finland, by the Finnish forestry service (Metsähallitus). 


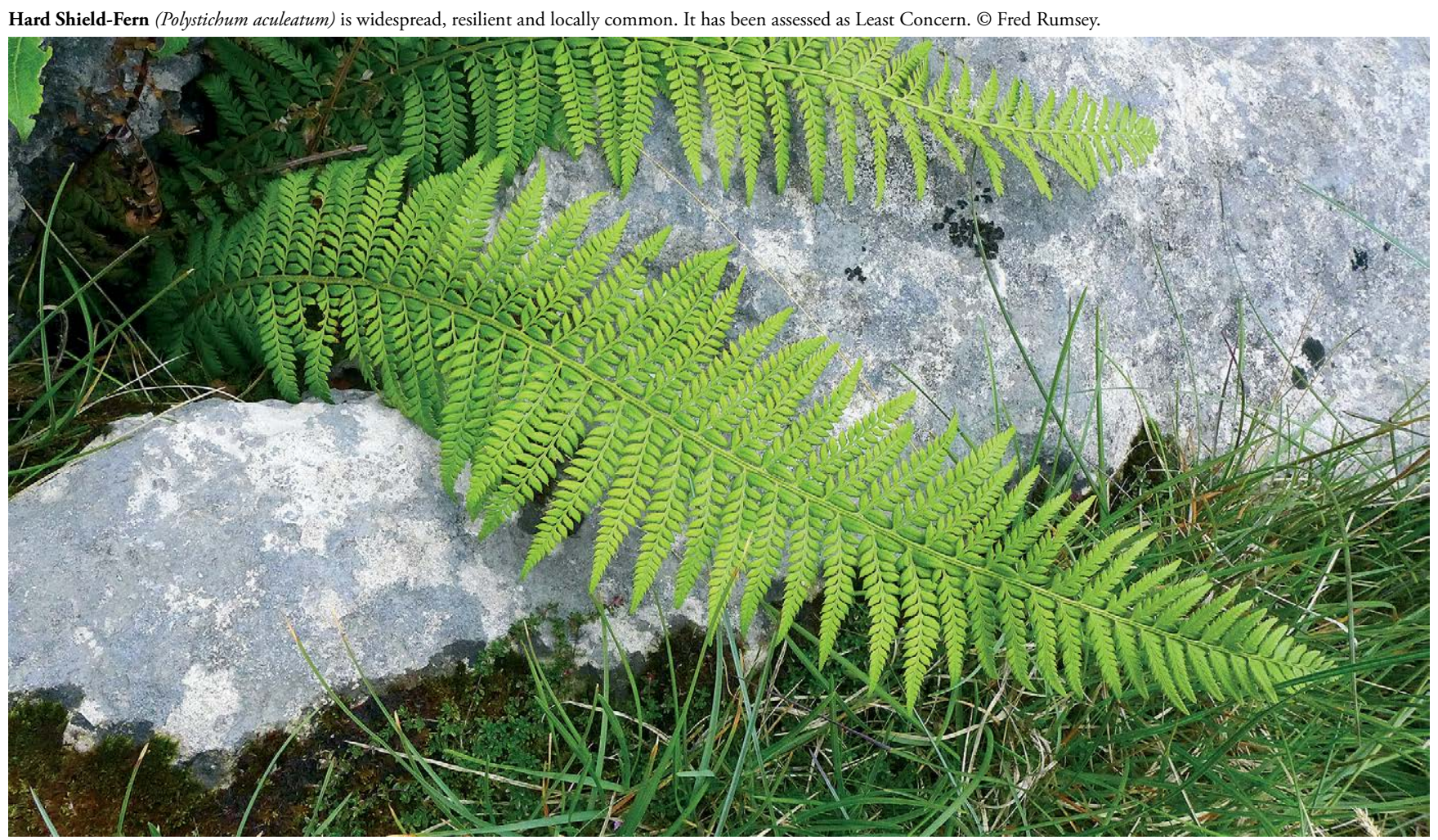

Plant habitat conservation efforts have in part been focused through the identification of Important Plant Areas (IPAs). IPAs are internationally significant sites for wild plants and threatened habitats. Identified at a national level, they provide a framework for implementing Target 5 of the CBD GSPC, and are a tool for targeting conservation actions on wild plants and in situ habitat protection. IPAs contain over 700 of the most threatened species in Europe and include millions of hectares of the most threatened habitats. At least 1,770 IPAs have been identified in 16 European countries (Anderson and Radford 2010).

Another form of protection stems from the concept of Plant Micro-Reserves (PMRs), which are present in several European countries. This is based on the use of vegetation fragments as small-scale reserves to conserve and monitor populations of rare, endemic and threatened species (Laguna 2001, 2014; Heywood 2015). It is built on the basis of a voluntary but nonreversible contribution of land property, both public and private, with the goal of creating a network of microareas (Laguna 2001, Laguna et al. 2016).

The EU has committed to a long-term (2050) vision and mid-term headline target for biodiversity, which is "To halt the loss of biodiversity and the degradation of ecosystem services in the EU by 2020 and restore them in so far as possible, while stepping up the EU contribution to averting global biodiversity loss." This target underpins the EU Biodiversity Strategy 2011-2020. The establishment of these policy instruments indicates the high political commitment to biodiversity, the need to monitor its status and to assess progress towards meeting conservation objectives and targets. Measuring whether policy targets have been met is only possible by establishing comprehensive monitoring programmes that allow the gathering of the necessary data for a reliable reassessment in the coming years. In order to reach these targets, immediate conservation action for species with a high extinction risk is needed.

Most European countries have developed specific actions at the national or regional level in order to enhance lycopod and fern populations. National Red Lists or Red Data Books of vascular plants species are available for the following countries: Albania (Government of Albania 2013), Austria (Niklfeld and Schratt-Ehrendorfer 1999), Belarus (Kachanovskiy et al. 2015), Belgium (for Flanders; Van Landuyt et al. 2006), Bosnia (Šilić 1996), Bulgaria (Petrova and Vladimirov 2009), Croatia (Nikolić and Topić 2007), Czech Republic (Grulich 2012), Cyprus (Tsintides et al. 2007), Denmark (NERI 2007), Estonia (Lilleleht 2008), Finland (Rassi et al. 2010), France (UICN France, FCBN and MNHN 2012), Germany (Ludwig and Schnittler 1996), Great Britain (Cheffings and Farrell 2005), Greece (Phitos et al. 1995), Hungary (Király 2007), Iceland (Náttúrufræðistofnun Islands 1996, 
Oblong Woodsia (Woodsia ilvensis) suffered a decline in the past due to over-harvesting in the United Kingdom, but its current population trend is stable. It has been assessed as Least Concern. (C) Fred Rumsey.

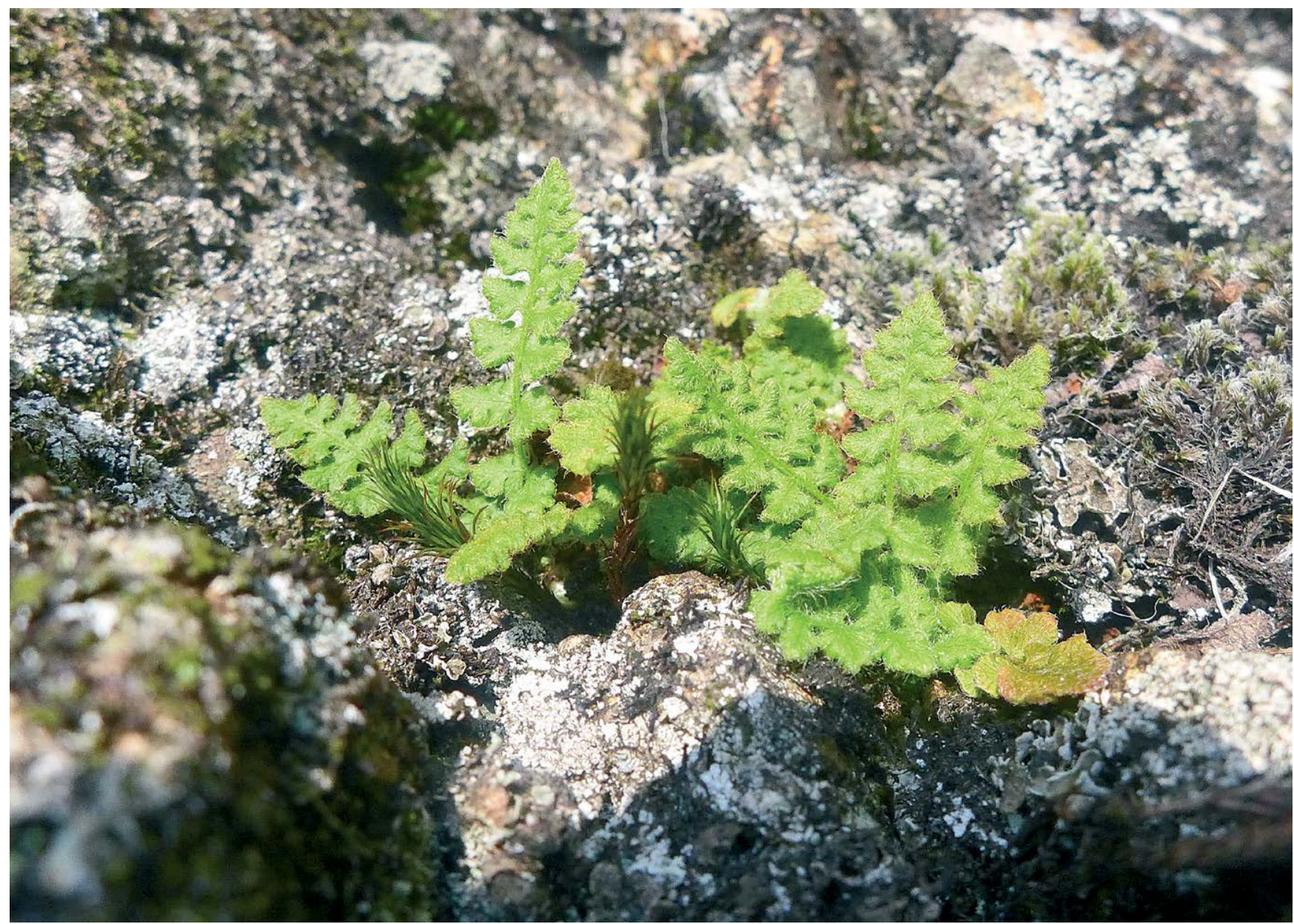

2008), Ireland (Wyse Jackson et al. 2016), Italy (Rossi et al. 2013), Latvia (Andrušaitis 2003), Liechtenstein (Broggi et al. 2006), Lithuania (Rašomavičius 2007), Luxembourg (Colling 2005), Malta (Lanfranco 1989), Moldova (Duca et al. 2015), the Netherlands (van der Meijden et al. 2000), Norway (Henriksen and Hilmo 2015), Poland (Mirek et al. 2006), Romania (Dihoru and Negrean 2009), Russia (Trutnev et al. 2008), Serbia (Stevanović 1999), Slovakia (Eliáš et al. 2015), Slovenia (Skoberne 1996), Spain (Bañares et al. 2010), Sweden (ArtDatabanken 2015), Switzerland (Moser et al. 2002) and Ukraine (Didukh 2009). In addition, The Carpathian Red List (Witkowski et al. 2003) assessed the species at the level of the Carpathians, but also assigned country-level Red List Categories for Austria, Czech Republic, Romania, Poland, Slovakia, Ukraine and Hungary.

In most countries there are regional Red Lists available. In general, the majority of countries in Europe can count on a Red List of vascular plants. However, there are some countries in which no national Red List has been developed (i.e., Montenegro, the Former Yugoslav Republic of Macedonia, Portugal). It is also noteworthy that some national Red Lists are outdated and should be maintained and updated in order to remain relevant.

In addition, several countries have developed management or action plans for several species, and have legislation in place to protect certain species legally (e.g., the Bulgarian Biological Diversity Act includes fern and lycopod species). Some examples of successful action plans include Woodsia ilvensis in the UK (McHaffie 2006), Trichomanes speciosum in Ireland (NPWS/NIEA 2008) or Isoëtes hystrix in France (Guitton and Thomassin 2010). LIFE projects have been undertaken at the European level to enhance the status of certain habitats and species, some of which have focused on specific species of ferns and lycopods, or produced management plans as a result of these projects.

Furthermore, nature engineering and restoration have resulted in an unexpected increase in some rare species such as Pilularia globulifera in eastern Netherlands (Bremer 2002). In the Iberian Peninsula, a study was also carried out in order to develop a conservation priority list based on aquatic plant communities. It resulted in amphibious communities related to oligotrophic 
environments with a bioclimatic Atlantic distribution and characterised by Isoëtes and Pilularia species being the most important vegetation conservation target (Benavent et al. 2014).

Re-introduction of several fern species has also taken place in Europe. Some examples include Woodsia ilvensis in Estonia (Aguraiuja 2011) and in the UK (McHaffie 2006), or Marsilea quadrifolia in the Ebro Delta in Spain (Estrelles et al. 2001) and in Germany (SchneiderBinder 2014).

\subsection{Red List versus priority for conservation action}

Assessing the extinction risk and setting conservation priorities are related but distinct processes. The purpose of the IUCN Red List assessment is to produce a relative estimate of the likelihood of extinction of a taxon. On the other hand, setting conservation priorities also takes into account other factors such as ecological, phylogenetical, historical, economical or cultural preferences for some taxa over others. Also, the probability of success of conservation actions, availability of funds or personnel, cost-effectiveness and legal frameworks for the conservation of threatened taxa is taken into account. In the context of regional risk assessments, a number of additional pieces of information are valuable for setting conservation priorities. For example, it is important to consider not only conditions within the region, but also the status of the taxon from a global perspective and the proportion of the global population that occurs within the region. The decision on how these three variables, and the other factors, are used for establishing conservation priorities is a matter for the regional authorities to determine, taking into account the assessment status of the species of concern.

Brittle Bladder Fern (Cystopteris fragilis) is usually common and gregarious, fast-growing and occurs in small groups or large numbers. It has been assessed as Least Concern. (C) Fred Rumsey.

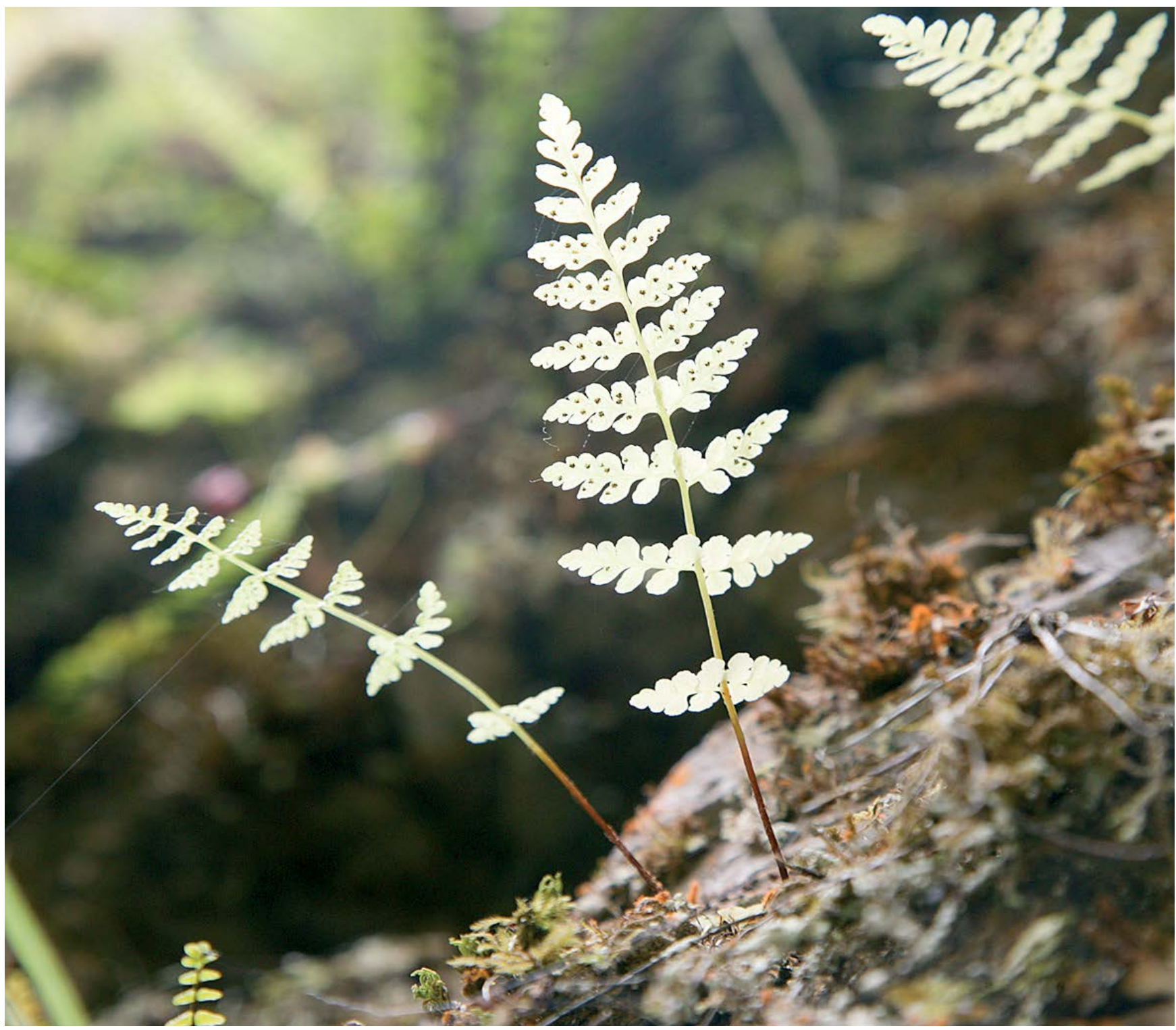




\section{Wetland ferns and lycopods}

Most ferns have higher moisture requirements than many other plants, but some particular species have even higher requirements than most. In particular, there are five fern and lycopod genera that are critically dependent upon wetlands. All the water-clovers (Marsilea spp.) and pillworts (Pilularia spp.) in Europe are entirely dependent on periodic wetlands, while the quillworts (Isoëtes spp.) vary from obligate submerged aquatics to species which occur in damp pastures. Salvinia species are floating ferns that form a mat on the water surface, while the Royal Fern (Osmunda regalis) can grow on dry land, but wild populations are usually found along streams or in periodically flooded forests.

There are other species that are strictly dependent on wetlands. For example, Marsh Fern (Thelypteris palustris) is typically present in boggy conditions, but often also grows out over relatively deep water as a floating mat, while its relative the Lemon-scented Fern (T. limbosperma) usually forms a fringe alongside upland water bodies, although it can also occur on large stands in the wetter mountain regions of Scotland and Norway. In total, 39 species of European ferns and lycopods can be considered wetland-dependent, of which 14 (35.9\%) are threatened. Of these, ten (71.4\%) are Isoëtes species, three (21.4\%) Marsilea and one (7.1\%) Pilularia. In contrast, all five of the wetland-dependent Equisetum and all three of the wetland-dependant Thelypteris, together with Osmunda regalis, Lycopodiella inundata, Selaginella selaginoides and Ophioglossum lusitanicum are considered Least Concern.

Many of the wetland-dependent species in the region are most strongly associated with seasonal wetlands including vernal pools (e.g., Pilularia minuta, Isoëtes todaroana), periodically flooded river banks (Marsilea batardae), or the drawdown zones of permanent wetlands (e.g., Isoëtes tenuissima), but some species are specifically dependent upon permanent lakes (e.g., Isoëtes azorica, I. sabatina) or streams and rivers (Isoëtes fluitans). In this context, the main threat to wetland-dependent species is the loss or degradation of their habitat. Isoëtes species usually thrive best in clear, oligotrophic, carbon-deficient and unpolluted water. However, rising nutrient levels are leading to increased competition from other vegetation, including macro-algae and invasive species, and increasing turbidity in the water column, often due to blooms of single-celled algae and cyanobacteria. Many of the species that depend on seasonal wetlands, such as Pilularia minuta and Marsilea batardae, are suffering from direct loss of their habitat when seasonally inundated habitats are drained and ploughed or lost to development and urbanisation. For many seasonal wetland species, conversion of seasonal pools to permanent ponds to provide water for stock or domestic uses will be enough to cause the extinction of local populations, as water level fluctuations are necessary for the reproduction and survival of these species. For a few species such as Marsilea strigosa and Pilularia minuta, coastal development for tourism is a particular threat as many of their populations occur in coastal regions of the Mediterranean that are particularly in demand for tourism and resort development. They are also affected by the threats caused by invasive alien species that escape from gardens and encroach on these fragile habitats.

Another significant problem for the conservation of some Isoëtes species in the region is a lack of long-term information. Isoëtes are not very conspicuous plants, often resembling a tuft of grass and growing partially or fully submerged. These plants are therefore often overlooked and field surveys are often difficult to carry out. Taxonomic distinction between species is also complicated and is usually based on microscopic characters such as the ornamentation of their spores. Recent molecular studies have contributed to differentiate some of these species complexes apart, to the extent that several species have been only recently described and no long-term data is yet available to assess habitat and population trends. Nevertheless, many species of Mediterranean Isoëtes face serious threats and the protection of these species and their fragile habitats is strongly recommended. 
Water Shamrock (Marsilea quadrifolia) occurs along the major river valleys in Europe and it is currently experiencing a decline mainly as a result of changes in the hydrological regime of water bodies and water pollution. It has been assessed as Vulnerable. (C) Karsten Horn.

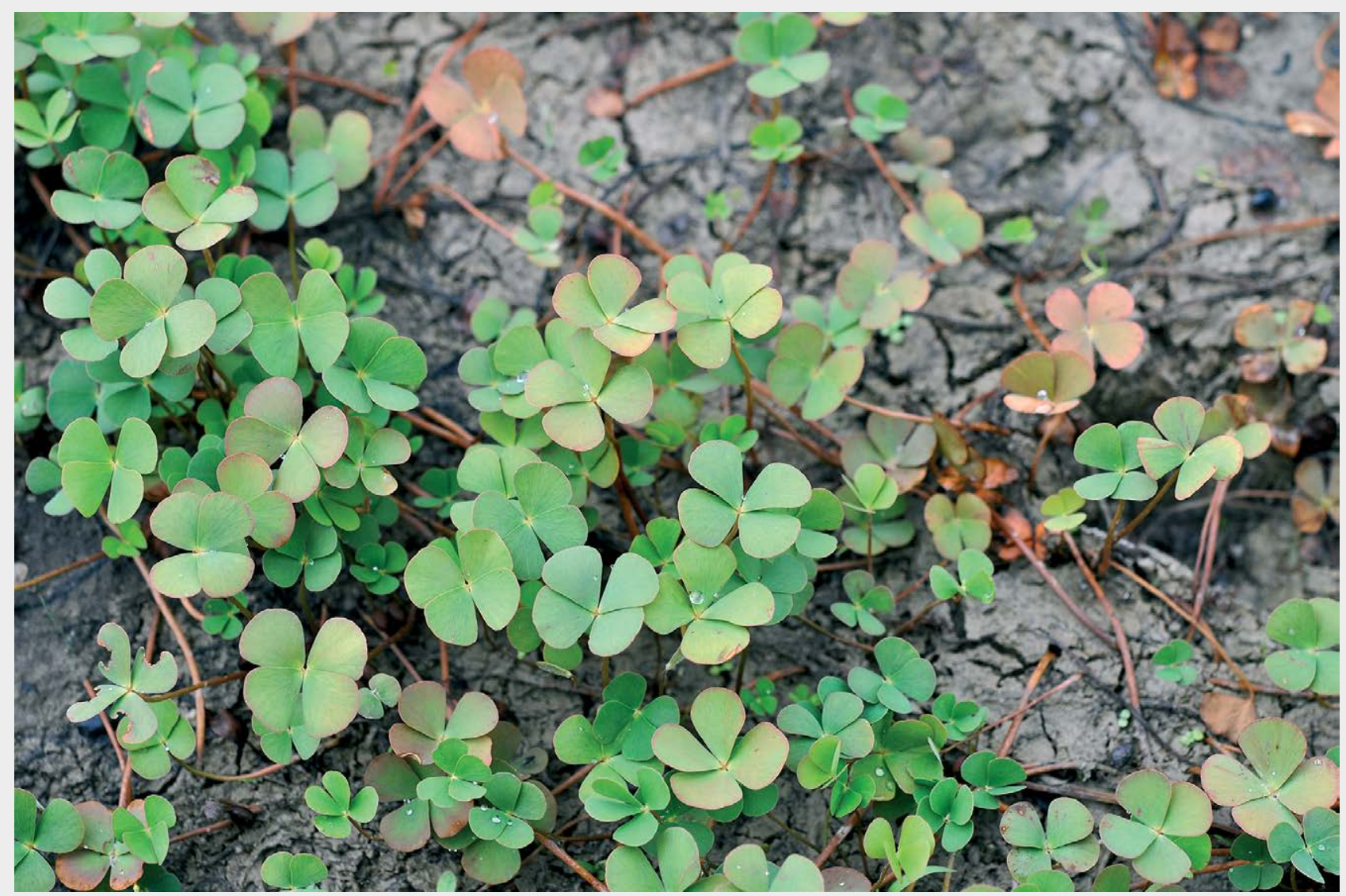

Pillwort (Pilularia globulifera) is endemic to Europe, but it is currently declining mainly due to stabilisation of water levels, drainage of temporary wetlands and invasive macrophytes. It has been assessed as Least Concern. (C) Karsten Horn.

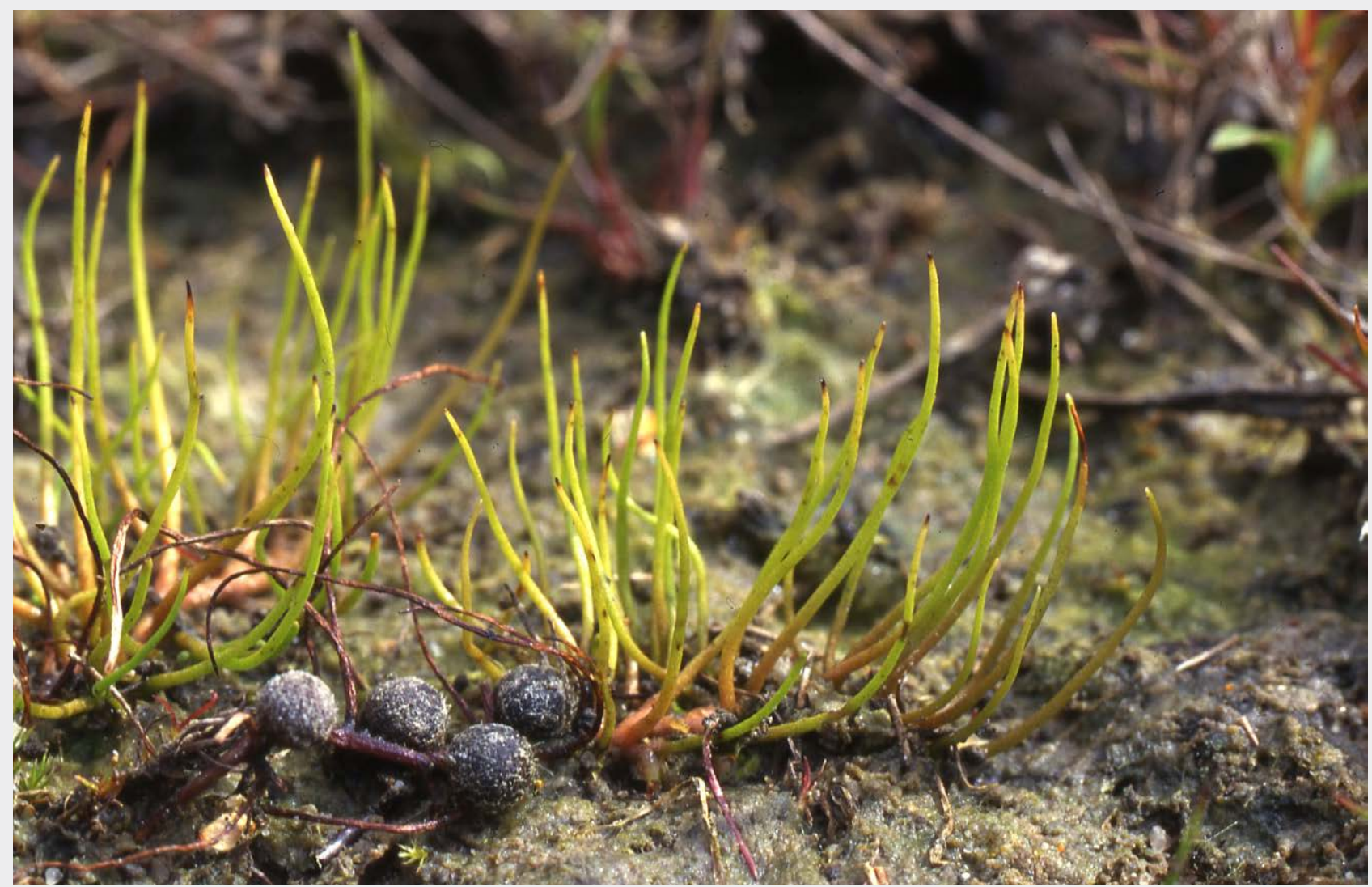




\section{Recommendations}

\subsection{Recommended actions}

Currently, 19.9\% of ferns and lycopods are threatened at the European regional level. Primarily these are oligotrophic aquatic species from the families Marsileaceae and Isoëtaceae (Table 4). The most important threats to ferns and lycopods in Europe come from the loss of suitable habitats as a consequence of urbanisation and infrastructure, human intrusions and disturbance, pollution and eutrophication, water use and management, deforestation, agricultural intensification and farming, land abandonment, and invasive alien species or native species that become more competitive due to fertilisation of the land.

Hence, improving the conservation status of ferns and lycopods, and preventing current and future declines in Europe, require increasing efforts and commitments from various parties, varying from nature reserve managements, industry and urban developers to local and national governments of both European and neighbouring countries. Below, a series of recommendations are proposed to strengthen the long-term survival of European ferns and lycopods:

\section{Policy measures}

- Use the European Red List to inform revisions and guide the implementation of relevant European legislation and policy to improve the status of threatened species.

- Update the European Red List every decade to ensure that the data remains current and relevant.

- Ensure that existing Natura 2000 sites and other protected areas provide adequate protection to threatened lycopod and fern species.

- Establish new protected areas to enhance the status of threatened species, so that each threatened and endemic European species is present in at least one protected area with an adequate adaptive management plan.

\section{Research and monitoring}

- Establish a monitoring programme in order to understand population sizes and trends of fern and lycopod species in Europe.

- Encourage scientific study on the biology of threatened species in order to better define the most important biotic and abiotic factors that may impact the status of these species.

Floating fern (Salvinia natans) naturally shows large subpopulation fluctuations. It is usually mistaken with Salvinia molesta in the field, which is an invasive species in Europe. It has been assessed as Near Threatened. (C) Richard Lansdown.

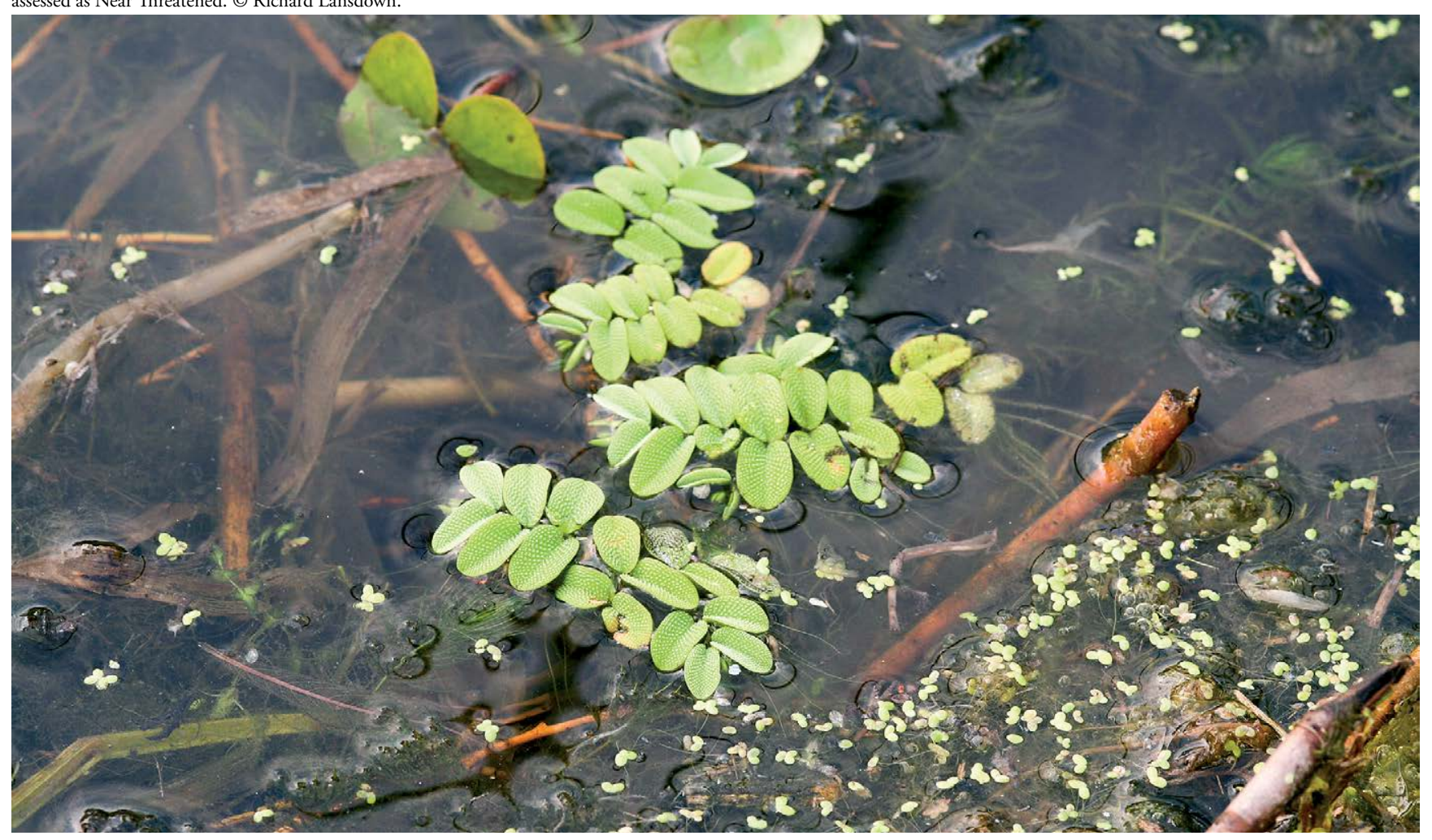


Toothed-leaved Clubmoss (Selaginella denticulata) is rarer in the eastern Mediterranean and faces localised threats, but it has an overall widespread distribution, is locally abundant and its overall population trend seems to be stable. It has been assessed as Least Concern. (C) Fred Rumsey.

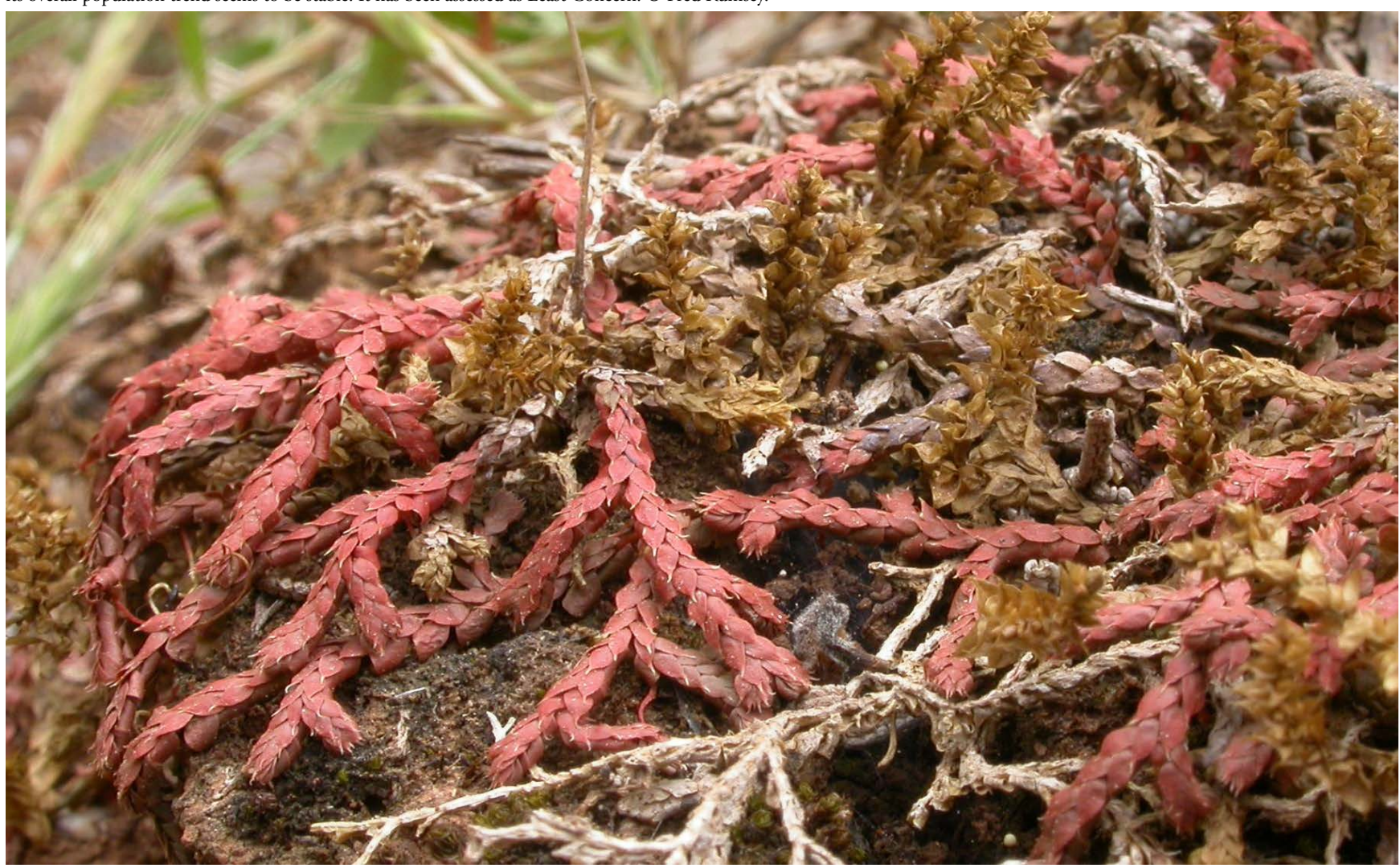

- Specific research for species that are possibly extinct should be carried out. Likewise, more research is needed on the distribution, population trends and taxonomy of Data Deficient taxa in order to assess their risk of extinction in Europe.

- The effects of certain threats that are not yet fully understood (e.g., climate change) should be studied.

- Enhance and strengthen the expert network of lycopods and ferns in Europe in order to improve the knowledge of European species.

\section{Action on the ground}

- Develop and implement conservation strategies and management plans for threatened species, with a special attention to endemic species.

- Habitat restoration is needed, especially in aquatic habitats and wetlands that are highly affected by pollution, canalisation, drainage and changes in hydrological regime.

- Habitat protection is recommended in order to avoid further degradation, together with the provision of suitable areas for ferns and lycopods.

- Maintain traditional land management in areas where threatened species are dependent on this.

- Management and control of invasive alien species, especially in areas where these are abundant, such as the Macaronesian islands.

\section{Ex situ conservation}

- Undertake ex situ conservation of species of conservation concern in botanical gardens or by national pteridological societies.

- Ensure the conservation of threatened ferns and lycopods in spore and gene banks.

- Reintroduce threatened and Regionally Extinct species in the wild in suitable habitats when necessary and possible.

\section{Awareness raising}

- When renovation works or road expansions threaten populations growing on mortared or dry-stone walls, public awareness should be raised on the importance of leaving some specimens in place in order to avoid local extinctions.

\subsection{Application of project outputs}

The European Red List of Lycopods and Ferns is part of a wider initiative aimed at assessing the status of all European species. It provides key resources for decision makers, policy makers, resources managers, environmental planners, NGOs and the concerned public by compiling large amounts of data on the population, ecology, habitats, threats and recommended 
conservation measures for each lycopod and fern species. These data are freely available on the IUCN Red List website (www.iucnredlist.org/initiatives/europe), on the European Commission's website (http://ec.europa.eu/ environment/nature/conservation/species/redlist) and through paper publications (see the list of European Red Lists published at the end of this report).

This European Red List of Lycopods and Ferns includes many threatened species, including highly exploited species that are used mainly for ornamental or medicinal purposes.

Red Lists are a dynamic tool that will evolve with time as species are re-assessed according to new information or situations. They are aimed at stimulating and supporting research, monitoring and conservation action at local, regional and international levels, especially for threatened, Near Threatened and Data Deficient species.

Each species assessment lists the major threats affecting the specific fern and lycopod species and conservation measures that are in place or recommended. This is useful to inform the application of conservation measures for each species. The outputs of this project can be applied to inform policies and to identify priority sites for biodiversity and priority species to include in research and monitoring programmes.

\subsection{Future work}

This project has mobilised a network of European and national fern and lycopod experts and has built on their extensive knowledge and expertise. It has benefitted greatly from the work and information held by relevant organisations and stakeholders, such as the Atlas Florae Europaeae (Finnish Museum of Natural History, Helsinki University), Plant Gateway, The Natural History Museum, London and the Royal Botanic Gardens, Kew.
Through the process of compiling data for the European Red List, a number of knowledge gaps have been identified. Across Europe there are significant geographic, geopolitical and taxonomic biases in the quality of data available on the distribution and status of species.

There is a clear need for drawing together information from all data compilation initiatives, under way or planned, and for a wider European fern and lycopod conservation action plan to be explored, developed and advanced. It is hoped that by presenting this assessment, local, national, regional and international research will be stimulated to provide new data and to improve on the quality of the data currently available.

Key challenges for the future are to improve monitoring and data quality and to further develop data openness and dissemination so that the information and analyses presented here can be updated and improved. This will contribute towards recommending conservation actions based on a solid scientific basis. The further dissemination of this information to concerned European citizens will also lead to progressive policies at various jurisdictional levels that promote conservation.

If the fern and lycopod assessments are periodically updated, they will enable the changing status of these species to be tracked through time via the production of a Red List Index (Butchart et al. 2004, 2005, 2006, 2007). To date, this indicator has been produced for birds, mammals, amphibians and reptiles at the European regional level and has been adopted as one of the headline biodiversity indicators to monitor progress towards halting biodiversity loss in Europe by 2020 (EEA 2007). The development of such an index will be important to evaluate progress towards meeting Target 6 of the EU Biodiversity Strategy in order to step up its contribution to avert global biodiversity loss, and Aichi Target 12 of the CBD, which focuses on preventing the extinction of known threatened species and improving their status. 


\section{References}

Aguraiuja, R. 2011. Reintroduction of the endangered fern species Woodsia ilvensis to Estonia: a long-term pilot study. Biodiversity and Conservation 20: 391400. https://doi.org/10.1007/s10531-010-9970-2

Allen, D.J., Bilz, M., Leaman, D.J., Miller, R.M., Timoshyna, A. and Window, J. 2014. European Red List of Medicinal Plants. Luxembourg: Publications Office of the European Union.

Anderson, S. and Radford, E.A. 2010. Important Plant Areas in Europe 2002-2010. Priority sites for plants and people. Salisbury: Plantlife International. Available online from: http://www.plantlife.org.uk/uploads/ documents/European_IPA_brochure_2.pdf

Andrušaitis, G. (ed.) 2003. Red data book of Latvia, vol. 3. Vascular plants. Riga: Institute of Biology, Latvia University. 691 pp. (In Latvian). [Latvijas sarkanā grämata. 3. sējums. Vaskulārie augi. LU Biologijas institūts, Rìga].

ArtDatabanken 2015. Rödlistade arter i Sverige 2015. ArtDatabanken SLU, Uppsala.

Bañares, Á., Blanca, G., Güemes, J., Moreno, J.C. and Ortiz, S. (eds.). 2010. Atlas y libro rojo de la flora vascular amenazada de España. Adenda 2010. Dirección General de Medio Natural y Política Forestal (Ministerio de Medio Ambiente, y Medio Rural y Marino) - Sociedad Española de Biología de la Conservación de Plantas, Madrid. 170 pp.

Beaton, C. and Buckland, G. 1975. The magic image: the genius of photography from 1839 to the present day. Little Brown and Company, Boston.

Benavent-González, A., Lumbreras, A. and Molina, J.A. 2014. Plant communities as a tool for setting priorities in biodiversity conservation: a novel approach to Iberian aquatic vegetation. Biodiversity and Conservation 23: 2135-2154. https://doi.org/10.1007/s10531-014-07093

Bilz, M., Kell, S.P., Maxted, N. and Lansdown, R.V. 2011. European Red List of Vascular Plants. Luxembourg: Publications Office of the European Union.

BirdLife International 2015. European Red List of Birds. Luxembourg: Publications Office of the European Union.

Broggi, M.F., Waldburger, E. and Staub, R. 2006. Rote Liste der gefährdeten und seltenen Gefässpflanzen des Fürstentums Lichtenstein. Amtlicher Lehrmittelverlag, Vaduz (Naturkundliche Forschung im Fürstentum
Liechtenstein; Bd. 24). ISBN 3-9521855-8-2.

Bremer, P. 2002. De toename van Pilularia globulifera L. (Pilvaren) in Overijssel. Gorteria 28: 81-88.

Butchart, S.H.M., Akcakaya, H.R., Chanson, J., Baillie, J.E.M., Collen, B., Quader, S., Turner, W.R., Amin, R., Stuart, S.N. and Hilton-Taylor, C. 2007. Improvements to the Red List Index. PloS ONE 2(1): e140. https://doi.org/10.1371/journal. pone. 0000140

Butchart, S.H.M., Akcakaya, H.R., Kennedy, E. and Hilton-Taylor, C. 2006. Biodiversity indicators based on trends in conservation status: strengths of the IUCN Red List Index. Conservation Biology 20: 579-581. https://doi.org/10.1111/j.15231739.2006.00410.x

Butchart, S.H.M., Stattersfield, A.J., Baillie, J.E.M., Bennun, L.A., Stuart, S.N., Akcakaya, H.R., HiltonTaylor, C. and Mace, G.M. 2005. Using Red List Indices to measure progress towards the 2010 target and beyond. Philosophical Transactions of the Royal Society of London B 360: 255-268.

Butchart, S.H.M., Stattersfield, A.J., Bennun, L.A., Shutes, S.M., Akcakaya, H.R., Baillie, J.E.M., Stuart, S.N., Hilton-Taylor, C. and Mace, M.M. 2004. Measuring global trends in the status of biodiversity: Red List Indices for birds. PLoS Biology 2: e383. https://doi.org/10.1371/journal.pbio.0020383

Cao, H., Chai, T.T., Wang, X., Morais-Braga, M.F.B., Yang, J.H., Wong, F.C., Wang, R., Yao, H., Cao, J., Cornara, L., Burlando, B. Wang, Y., Xiao, J. and Coutinho, H.D.M. 2017. Phytochemicals from fern species: potential for medicine applications. Phytochemistry Reviews 16(3): 379-440. doi: 10.1007/ s11101-016-9488-7.

Cheffings, C. M. and Farrell, L. (eds.) 2005. The vascular plant Red Data List for Great Britain. Species status no. 7. Joint Nature Conservation Committee, Peterborough.

Christenhusz, M. and Raab-Straube, E. von. 2013. Polypodiopsida. Euro+Med Plantbase-the information resource for Euro-Mediterranean plant diversity. Available online from: http://ww2.bgbm.org/Euro PlusMed/PtaxonDetail.asp? NameCache= PolypodiopsidaandPTRefFk=7500000. Accessed on 5 February 2017.

Christenhusz, M.J.M. and Byng, J.W. 2016. The number 
of known plants species in the world and its annual increase. Phytotaxa 261: 201-217. http://dx.doi. org/10.11646/phytotaxa.261.3.1

Christenhusz, M.J.M. and Chase, M.W. 2014. Trends and concepts in fern classification. Annals of Botany 113: 571-594. https://doi.org/10.1093/aob/mct299

Colling, G. 2005. Red List of the vascular plants of Luxembourg. Ferrantia 42, 1-77.

Convention on Biological Diversity (CBD) 2011. Aichi Biodiversity Targets. Available online from: https:// www.cbd.int/sp/targets/. Accessed on 8 February 2017.

Cox, N.A. and Temple, H.J. 2009. European Red List of Reptiles. Luxembourg: Office for Official Publications of the European Communities.

Council of Europe. 2014. European Pharmacopoeia. Strasbourg: Council of Europe.

Crawford, D.J., Mort, M.E. and Archibald, J.K. 2005. Biosystematics, chromosomes and molecular data: melding the old and the new. Taxon 54(2): 285-289. https://doi.org/10.2307/25065356

Crouch, H.J. and Rumsey, F.J. 2010. Changes in the fern flora of the city of Bath. Somerset Archaeology and Natural History 153: 233-246.

Cuttelod, A., García, N., Abdul Malak, D., Temple, H. and Katariya, V. 2008. The Mediterranean: a biodiversity hotspot under threat. In: J.-C. Vié, C. Hilton-Taylor and S.N. Stuart (eds), The 2008 Review of the IUCN Red List of Threatened Species. IUCN, Switzerland.

de Jong, Y., Verbeek, M., Michelsen, V., Bjørn, P., Los, W., Steeman, F., Bailly, N., Basire, C., Chylarecki, P., Stloukal, E., Hagedorn, G., Wetzel, F., Glöckler, F., Kroupa, A., Korb, G., Hoffmann, A., Häuser, C., Kohlbecker, A., Müller, A., Güntsch, A., Stoev, P. and Penev, L. 2014. Fauna Europaea - all European animal species on the web. Biodiversity Data Journal 2: e4034. https://doi.org/10.3897/BDJ.2.e4034

Desvaux, M. 1827. Prodrome de la famille des fougères. Mémoires de la Société Linnéenne de Paris, 2 me partie 6: 171-337.

Didukh, Y.P. (ed.) 2009. Red data book of Ukraine. Globalkonsaltyng, Kyiv. 912 pp. (In Ukrainian). [Vegetable kingdom [Chervona knyga Ukrainy. Roslynnyi svit.].

Dihoru, G. and Negrean, G. 2009. Red Book of vascular plants of Romania. Editura Academiei Române, Bucureşti. ISBN 978-973-27-1705-9. 630 p. (In Romanian). [Cartea roşie a plantarelor vasculare din România].
Duca, G., Chirică, L., Toderaş, I. and Teleuţă, A. 2015. Cartea roşie a Republicii Moldova [The Red Book of the Republic of Moldova]. Î.E.P. Ştiinţa. $3^{\text {rd }}$ ed. 492 pp. ISBN 978-9975-67-998-5. (Bilingual).

EC 2016. Nature and Biodiversity Newsletter 40. European Commission. Available online from: http:// ec.europa.eu/environment/nature/info/pubs/ docs/ nat2000newsl/nat40_en.pdf. Accessed on 10 April 2017.

EEA 2007. Halting the loss of biodiversity by 2010: proposal for a first set of indicators to monitor progress in Europe. EEA Technical Report No. 11/2007. Luxembourg: Publications Office of the European Union.

EEA 2015. Ecological footprint of European countries. European Environment Agency. Available online from: http://www.eea.europa.eu/data-and-maps/indicators/ cological-footprint-of-european-countries/ ecologicalfootprint-of-european-countries-2. Accessed on 5 December 2016.

EEA 2016. Land use. European Environment Agency. Available online from: http://eea.europa.eu/themes/ landuse/intro. Accessed on 5 December 2016.

Eliáš, P., Dítě, D., Kliment, J., Hrivnák, R. and Feráková, V. 2015. Red List of ferns and flowering plants of Slovakia, 5th edition (October 2014). Biologia 70: 218-228.

Estrelles, E., Ibars, A.M., Iranzo, J. and Morales, F. 2001. Recuperación y reintroducción de Marsilea quadrifolia en los arrozales del delta del Ebro (Tarragona, España). Botanica Complutensis 25: 251-259.

Euro+Med. 2006-2016. Euro+Med PlantBase - the information resource for Euro-Mediterranean plant diversity. Available online from: http://ww2.bgbm. org/EuroPlusMed/. Accessed on 10 April 2017.

European Union. 2013. Guidelines on wilderness in Natura 2000. European Union.

Eurostat 2015. National accounts and GDP. European Commission Eurostat. Available online from: http:// ec.europa.eu/eurostat/statistics-explained/index.php/ National_accounts_and_GDP. Accessed on 5 August 2016.

Fée, A.L.A. 1844-1873. Mémoires sur la famille des fougères, vols. 1-13. Strasbourg: Berger-Levrault.

Field, E.A. 1997. The use of powdered gloves in dental practice: a cause for concern? Journal of Dentistry 25: 209-214. https://doi.org/10.1016/S0300-5712(96)00013-9

Fraser-Jenkins, C.R. 1986. A classification of the genus Dryopteris (Pteridophyta: Dryopteridaceae). Bulletin of the British Museum (Natural History). Historical Series 74: 183-218. 
Freyhof, J. and Brooks, E. 2011. European Red List of Freshwater Fishes. Luxembourg: Publications Office of the European Union.

Government of Albania 2013. Red List of wild flora and fauna, Albania. Approved by Ministerial Order 1280, 20.1.2013. Tirana.

Grulich, V. 2012. Red List of vascular plants of the Czech Republic: $3^{\text {rd }}$ edition. Preslia 84: 631-645.

Guitton, H. and Thomassin, G. 2010. Plan de conservation en faveur de l'Isoète épineux (Isoetes histrix Bory 1844) en région Pays de la Loire. Nantes, Antenne régionale des Pays de la Loire.

Hasebe, M., Ito, M., Kofuji, R., Ueda, K. and Iwatsuki, K. 1993. Phylogenetic relationships of ferns deduced from $r b c L$ gene sequences. Journal of Molecular Evolution 37: 476-482. https://doi.org/10.1007/ BF00160428

Hawkins, B.A. and Diniz-Filho, J.A.F. 2004. 'Latitude' and geographic patterns in species richness. Ecography 27: 268-272. https://doi. org/10.1111/j.0906-7590.2004.03883.x

Henriksen, S. and Hilmo, O. 2015. Norsk rødliste for arter 2015. Artsdatabanken, Norge.

Heywood, V.H. 2015. In situ conservation of plant species - an unattainable goal? Israel Journal of Plant Sciences 63: 211-231. https://doi.org/10.1080/0792 9978.2015.1035605

Hochkirch, A., Nieto, A., García Criado, M., Cálix, M., Braud, Y., Buzzetti, F.M., Chobanov, D., Odé, B., Presa Asensio, J.J., Willemse, L., Zuna-Kratky, T., Barranco Vega, P., Bushell, M., Clemente, M.E., Correas, J. R., Dusoulier, F., Ferreira, S., Fontana, P., García, M.D., Heller, K.-G., Iorgu I.Ș., Ivković, S., Kati, V., Kleukers, R., Krištín, A., LemonnierDarcemont, M., Lemos, P., Massa, B., Monnerat, C., Papapavlou, K.P., Prunier, F., Pushkar, T., Roesti, C., Rutschmann, F., Şirin, D., Skejo, J., Szövényi, G., Tzirkalli, E., Vedenina, V., Barat Domenech, J., Barros, F., Cordero Tapia, P.J., Defaut, B., Fartmann, T., Gomboc, S., Gutiérrez-Rodríguez, J., Holuša, J., Illich, I., Karjalainen, S., Kočárek, P., Korsunovskaya, O., Liana, A., López, H., Morin, D., Olmo-Vidal, J. M., Puskás, G., Savitsky, V., Stalling, T. and Tumbrinck, J. 2016. European Red List of grasshoppers, crickets and bush-crickets. Luxembourg: Publications Office of the European Union.

Ide, J.M., Jermy, A.C. and Paul, A.M. (eds.) 1992. Fern horticulture: past, present and future perspectives. Intercept, Andover. 308 pp.

In 't Veld, T. 1981. Het groene mirakel, zin en onzin uit het plantenrijk. Ploegsma, Amsterdam.

IUCN 2011. Guidelines for reporting on proportion threatened. Version 1.0. In: IUCN. 2011. Guidelines for appropriate uses of IUCN Red List data. Incorporating the guidelines for reporting on proportion threatened and the guidelines on scientific collecting of threatened species. Version 2. Adopted by the IUCN Red List Committee and IUCN SSC Steering Committee. Downloadable from: http://www. iucnredlist.org/documents/RL_Guidelines_Data_Use. pdf

IUCN 2012a. IUCN Red List categories and criteria: Version 3.1. Second edition. Gland, Switzerland and Cambridge, UK: IUCN.

IUCN 2012b. Guidelines for application of IUCN Red List criteria at regional and national levels. Version 4.0. IUCN Species Survival Commission. Gland: IUCN.

IUCN 2014. Guidelinesforusing the IUCNRedListcategories and criteria. Version 11. Prepared by the Standards and Petitions Subcommittee. Gland, Switzerland and Cambridge, UK: IUCN. Available at: http://www. iucnredlist.org/documents/RedListGuidelines.pdf.

IUCN 2015. European species under threat. Overview of European Red Lists results. Downloadable from: https:// www.iucn.org/downloads/red_list_overview_new_1. pdf

Jalas, J. and Suominen, J. 1972. Atlas florae Europeae. Distribution of vascular plants in Europe. 1. Pteridophyta (Psilotaceae to Azollaceae). The Committee for Mapping the Flora of Europe and Societas Biologica Fennica Vanamo. Helsinki. 121 pp.

Janauer, G.A., Albrecht, J. and Stratmann, L. 2015. Synergies and conflicts between Water Framework Directive and Nature 2000: legal requirements technical guidance and experience from practice. In: Ignar, S. and Grygoruk, M. (eds.), Wetlands and Water Framework Directive. Protection, management and climate change. GeoPlanet: Earth and Planetary Sciences. Springer Open, ISSN 2190-5193, pp. 9-29.

Juslén, A., Väre, H. and Wikstrom, N. 2011. Relationships and evolutionary origins of polyploid Dryopteris (Dryopteridaceae) from Europe inferred using nuclear $p g i C$ and plastid $t r n L-F$ sequence data. Taxon 2011(60): 1284-1294.

Kachanovskiy, I.M., Nikiforov, M.E. and Parfionov, V.I. (eds.) 2015. Red data book of the Republic of Belarus: rare and threatened plants of native species. $4^{\text {th }}$ ed. Pietras Brovka Belarussian encyclopaedia, Minsk. 448 p. [Качановский, И.М., Никифоров, М.Е., Парфенов, В.И. и Ар. 2015. Красная книга Республики Беларусь: редкие и находящиеся 
поА угрозой исчезновения виды Аикорастущих растений растения. 4-е изА. Минск: Беларуская Энцыклапедыя імя Петруся Броўкі. 448 с.] ISBN 978-985-11-0843-1.

Kalkman, V.J., Boudot, J.-P., Bernard, R., Conze,K.-J., De Knijf, G., Dyatlova, E., Ferreira, S., Jović, M., Ott, J., Riservato, E. and Sahlén, G. 2010. European Red List of Dragonflies. Luxembourg: Publications Office of the European Union.

Király, G. (ed.). 2007. Vörös Lista: a magyarországi edényes flóra veszélyeztetett fajai [Red List of the vascular flora of Hungary]. 73 pp. Saját kiadás, Sopron.

Kluge, J., Kessler, M. and Dunn, R.R. 2006. What drives elevational patterns of diversity? A test of geometric constraints, climate and species pool effects for pteridophytes on an elevational gradient in Costa Rica. Global Ecology and Biogeography 15: 358-371. https://doi.org/10.1111/j.1466-822X.2006.00223.x

Laguna, E. 2001. The micro-reserves as a tool for conservation of threatened plants in Europe. Nature and environment series, No. 121. Council of Europe Publishing, Strasbourg.

Laguna, E. 2014. Origin, concept and evolution of plant micro-reserves: the pilot network of the Valencian Community (Spain). Pp. 14-24. In: Vladimirov, V. (ed.), A pilot network of small protected sites for conservation of rare plants in Bulgaria. IBER-BAS and MoEW, Sofia.

Laguna, E., Fos, S., Jiménez, J. and Volis, S. 2016. Role of microreserves in conservation of endemic, rare and endangered plants of the Valencian region (Eastern Spain), Israel Journal of Plant Sciences 63: 320-332. https://doi.org/10.1080/07929978.2016.1256131

Lanfranco, E. 1989. The Flora. In: Schembri, P. J. and Sultana, J. (eds.) Red data book for the Maltese Islands. Ministry of Education, Malta.

Lee, C.H. and Shin, S.L. 2011. Chapter 24. Functional Activities of Ferns for Human Health. - In: Fernández, H., Kumar, A. and Revilla, M.A. (eds), Working with Ferns: Issues and Applications. Springer New York Dordrecht Heidelberg London. Pp. 347-359. ISBN 978-1-4419-7161-6, e-ISBN 978-1-4419-7162-3.

Lehtonen, S. 2011. Towards resolving the complete fern tree of life. PloS One 6: e24851. https://doi. org/10.1371/journal.pone.0024851

Lilleleht, V. (ed.). 2008. Eesti punane raamat [Red data book of Estonia]. Commission for Nature Conservation of the Estonian Academy of Sciences, Tartu.

Lindsay, J. 1794. Account of the germination and raising of ferns from the seed. Transactions of the
Linnean Society of London 2: 93-100. https://doi. org/10.1111/j.1096-3642.1794.tb00247.x

Linnaeus C. 1753. Species plantarum, etc., 2 vols. L. Salvius, Stockholm.

Linnaeus C. 1754. Genera plantarum, etc. L. Salvius, Stockholm.

Ludwig, G. and Schnittler, M. 1996. Red List of threatened plants in Germany [Rote Liste gefährdeter Pflanzen Deutschlands]. Bundesamt für Naturschutz, Bonn.

May, L.W. 1978. The economic uses and associated folklore of ferns and fern allies. The Botanical Review 44: 491-582. https://doi.org/10.1007/BF02860848

McHaffie, H. 2005 Athyrium distentifolium Tausch ex Opiz ( $A$. alpestre (Hoppe) Rylands ex T. MooreNon-Clairv.) including $A$. distentifolium var. flexile (Newman) Jermy. Journal of Ecology 93: 839-851. https://doi.org/10.1111/j.1365-2745.2005.01037.x

McHaffie, H. 2006. A reintroduction programme for Woodsia ilvensis (L.) R. Br. in Britain. Botanical Journal of Scotland 58: 75-80. https:// doi.org/10.1080/03746600608685108 https://doi.org/10.1080/03746600608685109

Mehltreter, M., Walker, L.R. and Sharpe, J.M. (eds.) 2010. Fern ecology. Cambridge University Press, Cambridge. 474 pp.

Merckx, V., Freudenstein, J., Kissling, J., Christenhusz, M.J.M., Stotler, R.E., Crandall-Stotler, B., Wickett, N., Rudall, P.J., Maas-van de Kamer, H. and Maas, P.J.M. 2012. Taxonomy and classification. In: Merckx, V. (ed.), Mycoheterotrophy, the biology of plants living on fungi. Heidelberg: Springer, pp. 19-104.

Mirek, Z., Zarzycki, K., Wojewoda, W. and Szelag, Z. (eds.) 2006. Red List of plants and fungi in Poland. W. Szafer Institute of Botany, Polish Academy of Sciences, Kraków.

Mittermeier, R.A., Robles Gil, P., Hoffmann, M., Pilgrim, J., Brooks, T., Mittermeier, C.G., Lamoreux, J. and Fonseca, G.A.B. 2004. Hotspots Revisited: Earth's Biologically Richest and Most Endangered Terrestrial Ecoregions. Mexico City: CEMEX, Conservation International and Agrupación Sierra Madre.

Moser, D., Gygax, A., Bäumler, B., Wyler, N. and Palese, R. 2002. Red List of the threatened ferns and flowering plants of Switzerland (Rote Liste der gefährdeten Farn- und Blütenpflanzen derSchweiz). Bundesamtfür Umwelt, Wald und Landschaft, Bern; Zentrum des Datenverbundnetzes der Schweizer Flora, Chambésy; Conservatoire et Jardin botaniques de la Ville de Genève, Chambésy.

Náttúrufræðistofnun Islands. 1996. Válisti 1 - Plöntur. Reykjavík: Náttúrufræðistofnun Islands. 
Náttúrufræðistofnun Islands. 2008. Red List of Vascular Plants. Available at: http://www.ni.is/midlun/utgafa/ valistar/plontur/valisti-haplantna. Accessed on 12 April 2017.

NERI (National Environmental Research Institute, Denmark). 2007. The Danish red data book. Roskilde Available at: http://www2.dmu.dk/1_Om_DMU/2_ Tvaer-funk/3_fdc_bio/projekter/redlist/redlist_ en.asp. Accessed on 12 April 2017.

Nieto, A., Ralph, G.M., Comeros-Raynal, M.T., Kemp, J., García Criado, M., Allen, D.J., Dulvy, N.K., Walls, R.H.L., Russell, B., Pollard, D., García, S., Craig, M., Collette, B.B., Pollom, R., Biscoito, M., Labbish Chao, N., Abella, A., Afonso, P., Álvarez, H., Carpenter, K.E., Clò, S., Cook, R., Costa, M.J., Delgado, J., Dureuil, M., Ellis, J.R., Farrell, E.D., Fernandes, P., Florin, A.-B., Fordham, S., Fowler, S., Gil de Sola, L., Gil Herrera, J., Goodpaster, A., Harvey, M., Heessen, H., Herler, J., Jung, A., Karmovskaya, E., Keskin, C., Knudsen, S.W., Kobyliansky, S., Kovačić, M., Lawson, J.M., Lorance, P., McCully Phillips, S., Munroe, T., Nedreaas, K., Nielsen, J., Papaconstantinou, C., Polidoro, B., Pollock, C.M., Rijnsdorp, A.D., Sayer, C., Scott, J., Serena, F., Smith-Vaniz, W.F., Soldo, A., Stump, E. and Williams, J.T. 2015. European Red List of Marine Fishes. Luxembourg: Publications Office of the European Union.

Niklfeld, H. and Schratt-Ehrendorfer, L. 1999. Rote Liste gefährdeter Farn- und Blütenpflanzen (Pteridophyta und Spermatophyta) Österreichs. 2. Fassung. In: Niklfeld, H. (ed.), Rote Listen gefährdeter Pflanzen Österreichs. Ed. 2. Wien, Grüne Reihe des Bundesministeriums für Umwelt, Jugend und Familie 10, pp. 33-151.

Nikolić, T. and Topić, J. (eds.) 2007. Red book of vascular flora of Croatia. Ministry of Culture, State Institution for Nature Protection, Zagreb.

NPWS / NIEA. 2008. All-Ireland Species Action Plan - Killarney Fern. Draft for public consultation. National Parks and Wildlife Service and Environment and Heritage Service, Northern Ireland.

Petrova, A. and Vladimirov, V. (eds.) 2009. Red List of Bulgarian vascular plants. Phytologia Balcanica 15: 63-94.

Phitos, D., Strid, A., Snogerup, S. and Greuter, W. (eds.) 1995. The red data book of rare and threatened plants of Greece. WWF-Greece, Athens.

PPG I (Schuettpelz, E. et al.) 2016. A community-derived classification for extant lycophytes and ferns. Journal of Systematics and Evolution 54: 563-603. https://doi. org/10.1111/jse. 12229

Presl, C.B. 1836. Tentamen pteridographiae, etc. Prague: Haase.

Presl, C.B. 1845. Supplementum tentaminis Pteriodographiae. Abhandlungen der Böhmischen Gesellschaft der Wissenschaften n. ser. 4: 261-380.

Presl, C.B. 1851. Epimeliae botanicae. Abhandlungen der Böhmischen Gesellschaft der Wissenschaften n. ser. 6: 361-624.

Rašomavičius, V. (ed.) 2007. Lietuvos raudonoji knyga [Red data book of Lithuania]. Vilnius, Lietuvos Respublikos aplinkos ministerija (Ministry of Environment of the Republic of Lithuania). ISBN 978-9955-692-71-3. 800 p. (In Lithuanian).

Rassi, P., Hyvärinen, E., Juslén, A. and Mannerkoski, I. (eds). 2010. The 2010 Red List of Finnish species. 685 pp. Ympäristöministeriö ja Suomen ympäristökeskus [Ministry of the Environment and Finnish Environment Institute], Helsinki.

RBTH. 2014. A tasty snack from a toxic plant. Available online from: https://www.rbth.com/amp/498489. Accessed on 10 June 2017.

Rhazi, M., Grillas, P., Charpentier, A. and Médail, F. 2004. Experimental management of Mediterranean temporary pools for conservation of the rare quillwort Isoëtes setacea. Biological Conservation 118: 675-684. https://doi.org/10.1016/j.biocon.2003.10.016

Rickards, R.B. 2000. The age of the earliest club mosses: the Silurian Baragwanathia flora in Victoria, Australia. Geological Magazine 137: 207-209. https:// doi.org/10.1017/S0016756800003800

Rossi, G., Montagnani, C., Gargano, D., Peruzzi, L., Abeli, T., Ravera, S., Cogoni, A., Fenu, G., Magrini, S., Gennai, M., Foggi, B., Wagensommer, R. P., Venturella, G., Blasi, C., Raimondo, F. M. and Orsenigo, S. 2013. Lista rossa della flora Italiana. 1. Policy Species e altre specie minacciate. Comitato Italiano IUCN e Ministero dell'Ambiente e della Tutela del Territorio e del Mare.

Rumsey, F.J. and Sheffield, E. 1996. Inter-generational ecological niche separation and the independent gametophyte' phenomenon. In: Camus, J. M., Gibby, M. and Johns, R. J. (Eds.) Pteridology in Perspective, Royal Botanic Gardens, Kew, Richmond, pp.563-570.

Rumsey, F.J., Sheffield, E. and Farrar, D.J. 1990. British filmy fern gametophytes. Pteridologist 2: 40-42.

Schneider-Binder, E. 2014. The four leaf water clover (Marsilea quadrifolial.) an endangered species. Aspects of conservation and management. Transylvanian Review of Systematical and Ecological Research 16: 
161-176. https://doi.org/10.1515/trser-2015-0011

Schneider, H., Schuettpelz, E., Pryer, K.M., Cranfill, R., Magallón, S. and Lupia, R. 2004. Ferns diversified in the shadow of angiosperms. Nature 428: 553-557. https://doi.org/10.1038/nature02361

Sessa, E.B., Zhang, L.-B., Väre, H. and Juslén, A. 2015. What we do (and don't) know about ferns: Dryopteris (Dryopteridaceae) as a case study. Systematic Botany 40: 387-399. https://doi.org/10.1600/036364415X688844

Sheehan, T.J. 1960. Effects of nutrition and potting media on growth and flowering of certain epiphytic orchids. Florida State Horticultural Society Proceedings 72: $352-354$.

Šilić, Č. 1996. The list of plant species (Pteridophyta and Spermatophyta) for the red book of Bosnia and Herzegovina. Glasnik Zemaljskog Muzeja Bosne i Hercegovine, Sarajevo.

Silva, L., Martins, M.C., Maciel, G.B. and Moura, M. 2009. Flora vascular dos Açores. Prioridades em conservação. Amigos dos Açores and CCPA, Ponta Delgada.

Simán, S.E., Povey, A.C., Ward, T.H., Margison, G.P. and Sheffield, E. 2000. Fern spore extracts can damage DNA. British Journal of Cancer, 83(1):69-73.

Singh, M., Singh, N., Khare, P.B. and Rawat, A.K.S. 2008. Antimicrobial activity of some important Adiantum species used traditionally in indigenous systems of medicine. Journal of Ethnopharmacology 2(115): 327329. https://doi.org/10.1016/j.jep.2007.09.018

Skoberne, P. 1996. Rdeci seznam ogrozenih praprotnic in semenk Slovenije [Red List of threatened vascular plants in Slovenia]. Lubljana.

Smith, J.E. 1793. Tentamen botanicum de filicum generibus dorsiferarum. Mémoires de l'Académie Royale des Sciences, Turin 5: 401-422.

Smith, J. 1841. An arrangement and definition of the genera of ferns. Journal of Botany, British and Foreign 4: 38-70, 147-198.

Smith, J. 1843. An arrangement and definition of the genera of ferns. London Journal of Botany 1: 419-438, 659-668; 2: 378-394.

Stewart W.N., Rothwell G.W. 1993. Paleobotany and the Evolution of Plants, 2nd Edn. New York: Cambridge University Press.

Stevanović, V. (ed.) 1999. The red data book of flora of Serbia I: extinct and critically endangered taxa. Institute for Protection of Nature of the Republic of Serbia, Belgrade.

Swartz, O. 1801. Genera et species filicum, etc. Journal für die Botanik [ed. Schrader H.A.] 1800: 1-120.

Temple, H.J. and Cox, N.A. 2009. European Red List of amphibians. Luxembourg: Office for Official
Publications of the European Communities.

Temple, H.J. and Terry, A. 2007. The status and distribution of European mammals. Luxembourg, Office for Official Publications of the European Communities. viii +48 pp.

Tourchi-Roudsari, M. 2014. Multiple Effects of Bracken Fern under in vivo and in vitro conditions. Asian Pacific Journal of Cancer Prevention, 15: 7505-7513. https://doi.org/10.7314/APJCP.2014.15.18.7505

Troia, A., Pereira, J.B., Kim, C. and Taylor, W.C. 2016. The genus Isoetes (Isoetaceae): a provisional checklist of the accepted and unresolved taxa. Phytotaxa 277: 101145. https://doi.org/10.11646/phytotaxa.277.2.1

Trutnev, Y.-P. (ed.) 2008. Red data book of the Russian Federation (plants and fungi). Tovarischestvo nauchnykh izdanyi KMK. Moscow. 855 p. (In Russian). [Трутнев, Ю.П. и Ар. 2008. Красная книга Российской Федерации (растения и грибы). Товарищество научных изданий КМК, Москва]. ISBN 958-5-87317-476-8.

Tsintides, T., Christodoulou, C.S., Delipetrou, P. and Georghiou, K. (eds.) 2007. To kokkino bibiio tho $x \lambda \omega p i \delta a \sigma$ th $\sigma$ Ky of Cyprus]. Cyprus Forestry Association: Lefkosia. ISBN 978-9963-9288-0-4. (Bilingual).

UICN France, FCBN and MNHN. 2012. La Liste rouge des espèces menacées en France - Chapitre Flore vasculaire de France métropolitaine : premiers résultats pour 1000 espèces, sous-espèces et variétés. UICN France, FCBN and MNHN: Paris, France.

UN DESA. 2015. World Population Prospects: The 2015 Revision. United Nations, Department of Economic and Social Affairs. Available online from: http://esa.un.org/unpd/wpp/ExcelData/population. htm. Accessed on 8 September 2016.

UNEP 2011. Pan-European 2020 Strategy For Biodiversity. With a focus on: Cooperation for the conservation and sustainable use of PanEuropean biodiversity and the coordinated national implementation of biodiversity-related Multilateral Environmental Agreements (MEAs). Nairobi: United Nations Environment Programme.

Van der Meijden, R., Odé, B., Groen, L.G., Witte, R. and Bal, D. 2000. Bedreigde en kwetsbare vaatplanten in Nederland. Basisrapport met voorstel voor de rode lijst. Gorteria 26: 85-208.

Van Landuyt, W., Vanhecke, L. and Hoste, I. 2006. Rode lijst van de vaatplanten van Vlaanderen en het Brussels Hoofdstedelijk Gewest. In: Van Landuyt, W., Hoste, I., Vanhecke, L., Van den Bremt, P., Vercruysse, E. and 
De Beer, D. (eds.) Atlas van de flora van Vlaanderen en het Brussels Gewest. NBO en Nationale Plantentuin van België, Brussels/Meise.

Wagner Jr., W.H. and Wagner, F.S. 1980. Polyploidy in pteridophytes. Basic Life Sciences 13: 199-214. https://doi.org/10.1007/978-1-4613-3069-1_11

Whittingham, S. 2012. Fernfever: thestory of pteridomania. Frances Lincoln, London.

Witkowski, Z.J., Król, W. and Solarz, W. (eds.) 2003. Carpathian list of endangered species. WWF and Institute of Nature Conservation, Polish Academy of Sciences, Vienna-Krakow. pp. 68.

Wu, S.-G., Xiang, J.-Y., Lu, S.-G., Wang, F.-G., Xing, F.-W., Dong, S.-Y., He, H., Zhang, L.-B., Barrington, D.S., Christenhusz, M.J.M. 2013. Dryopteris Adanson. In: Wu, Z.Y., Raven, P.H. and Hong, D.Y. [eds.], Flora of China, vol. 2-3 (Lycopodiaceae through Polypodiaceae), pp. 571-628. Science Press, Beijing, China and Missouri Botanical Garden Press, St. Louis, Missouri, USA.

Wyse Jackson, M., FitzPatrick, Ú., Cole, E., Jebb, M., McFerran, D., Sheehy Skeffington, M. and Wright, M. 2016. Ireland Red List No. 10: Vascular Plants. National Parks and Wildlife Service, Department of Arts, Heritage, Regional, Rural and Gaeltacht Affairs, Dublin, Ireland.

Yatskievych, G. 2003. Pteridophytes (Ferns). In: Encyclopedia of Life Sciences. John Wiley \& Sons, Ltd, www.els.net (Published online 26 FEB 2003). https://doi.org/10.1038/npg.els.0003679 


\section{Appendix 1. Red List status of European lycopods and ferns}

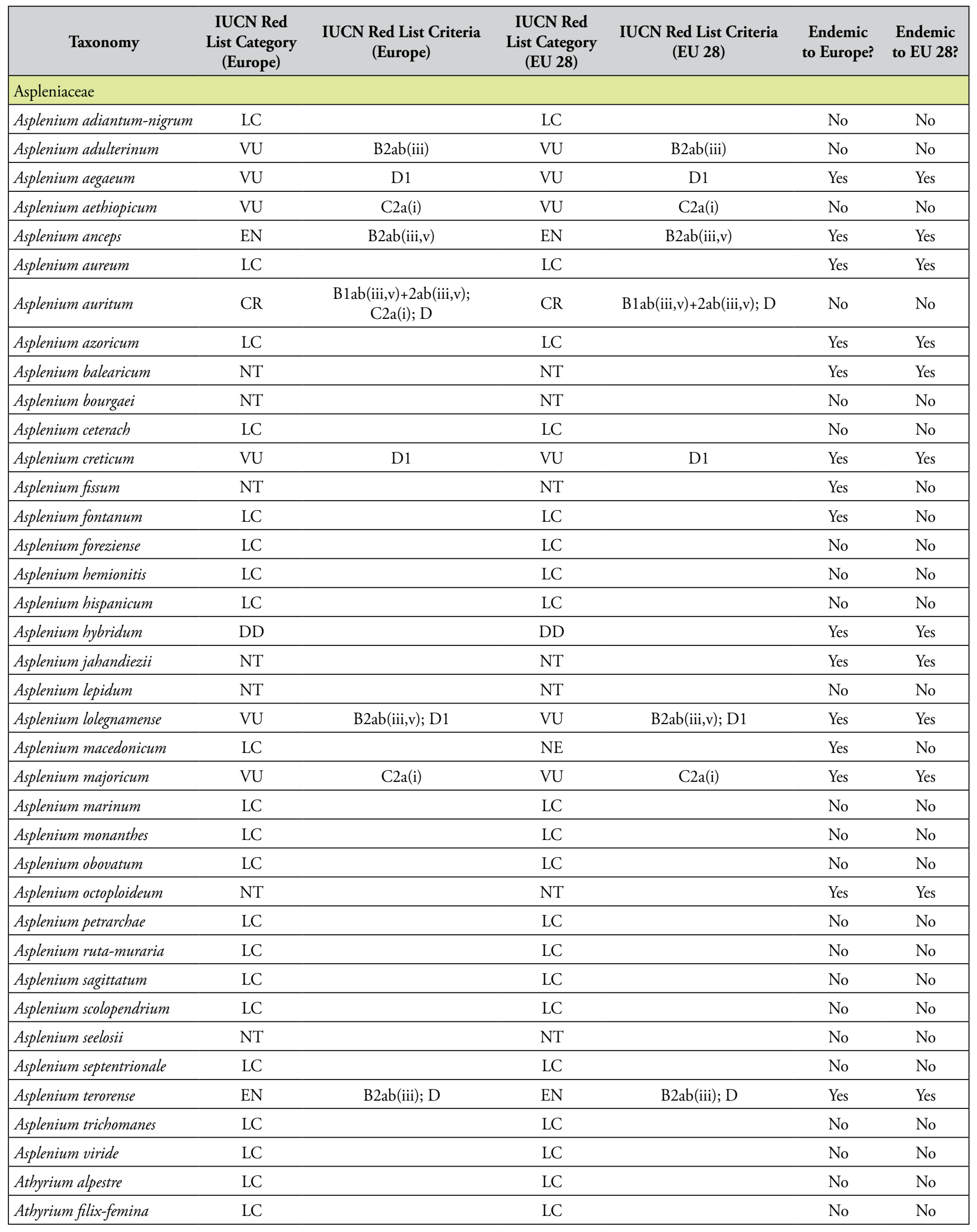




\begin{tabular}{|c|c|c|c|c|c|c|}
\hline Taxonomy & $\begin{array}{l}\text { IUCN Red } \\
\text { List Category } \\
\text { (Europe) }\end{array}$ & $\begin{array}{l}\text { IUCN Red List Criteria } \\
\text { (Europe) }\end{array}$ & $\begin{array}{l}\text { IUCN Red } \\
\text { List Category } \\
\text { (EU 28) }\end{array}$ & $\begin{array}{l}\text { IUCN Red List Criteria } \\
\text { (EU 28) }\end{array}$ & $\begin{array}{l}\text { Endemic } \\
\text { to Europe? }\end{array}$ & $\begin{array}{l}\text { Endemic } \\
\text { to EU } 28 \text { ? }\end{array}$ \\
\hline Blechnum spicant & LC & & LC & & No & No \\
\hline Cystopteris fragilis & LC & & LC & & No & No \\
\hline Cystopteris montana & LC & & LC & & No & No \\
\hline Cystopteris sudetica & NT & & $\mathrm{VU}$ & $\mathrm{B} 2 \mathrm{ab}(\mathrm{v})$ & No & No \\
\hline Diplazium caudatum & LC & & LC & & No & No \\
\hline Diplazium sibiricum & NT & & LC & & No & No \\
\hline Gymnocarpium dryopteris & LC & & LC & & No & No \\
\hline Gymnocarpium jessoense & LC & & LC & & No & No \\
\hline Gymnocarpium robertianum & LC & & LC & & No & No \\
\hline Onoclea struthiopteris & LC & & LC & & No & No \\
\hline Phegopteris connectilis & LC & & LC & & No & No \\
\hline Thelypteris dentata & LC & & LC & & No & No \\
\hline Thelypteris limbosperma & LC & & LC & & No & No \\
\hline Thelypteris palustris & LC & & LC & & No & No \\
\hline Thelypteris pozoi & LC & & LC & & No & No \\
\hline Woodsia alpina & LC & & LC & & No & No \\
\hline Woodsia glabella & LC & & LC & & No & No \\
\hline Woodsia ilvensis & LC & & LC & & No & No \\
\hline Woodsia pulchella & NT & & NT & & Yes & No \\
\hline Woodwardia radicans & $\mathrm{VU}$ & $\mathrm{A} 2 \mathrm{c}$ & $\mathrm{VU}$ & & No & No \\
\hline \multicolumn{7}{|l|}{ Cyatheaceae } \\
\hline Culcita macrocarpa & NT & & NT & & Yes & Yes \\
\hline \multicolumn{7}{|l|}{ Dennstaedtiaceae } \\
\hline Pteridium aquilinum & LC & & LC & & No & No \\
\hline Pteridium pinetorum & LC & & LC & & Yes & No \\
\hline \multicolumn{7}{|l|}{ Equisetaceae } \\
\hline Equisetum arvense & LC & & LC & & No & No \\
\hline Equisetum fluviatile & LC & & LC & & No & No \\
\hline Equisetum hyemale & LC & & LC & & No & No \\
\hline Equisetum palustre & LC & & LC & & No & No \\
\hline Equisetum pratense & LC & & LC & & No & No \\
\hline Equisetum ramosissimum & LC & & LC & & No & No \\
\hline Equisetum scirpoides & LC & & LC & & No & No \\
\hline Equisetum sylvaticum & LC & & LC & & No & No \\
\hline Equisetum telmateia & LC & & LC & & No & No \\
\hline Equisetum variegatum & LC & & LC & & No & No \\
\hline \multicolumn{7}{|l|}{ Hymenophyllaceae } \\
\hline Hymenophyllum maderense & CR & $\begin{array}{c}\text { B1ab(i,ii,iii,iv,v) } \\
\text { 2ab(i,iii,iii,iv,v); C2a(i,ii); D }\end{array}$ & CR & $\begin{array}{c}\text { B1ab(i,ii,iiii,iv,v) } \\
\text { 2ab(i,ii,iii,iv,v); C2a(i,ii); D }\end{array}$ & Yes & Yes \\
\hline Hymenophyllum tunbrigense & LC & & LC & & No & No \\
\hline Hymenophyllum wilsonii & LC & & LC & & Yes & No \\
\hline Trichomanes speciosum & LC & & LC & & No & No \\
\hline \multicolumn{7}{|l|}{ Isoëtaceae } \\
\hline Isoëtes azorica & $\mathrm{VU}$ & A4ce; C2a(i) & $\mathrm{VU}$ & A4ce; C2a(i) & Yes & Yes \\
\hline Isoëtes boryana & EN & $\begin{array}{c}\text { B1ab(ii,iii,iv,v)+2ab(ii,iii, } \\
\text { iv,v) }\end{array}$ & EN & $\begin{array}{c}\text { B1ab(ii,iii,iv,v)+2ab(ii,,iii } \\
\text {,iv,v) }\end{array}$ & Yes & Yes \\
\hline
\end{tabular}




\begin{tabular}{|c|c|c|c|c|c|c|}
\hline Taxonomy & $\begin{array}{l}\text { IUCN Red } \\
\text { List Category } \\
\text { (Europe) }\end{array}$ & $\begin{array}{l}\text { IUCN Red List Criteria } \\
\text { (Europe) }\end{array}$ & $\begin{array}{l}\text { IUCN Red } \\
\text { List Category } \\
\text { (EU 28) }\end{array}$ & $\begin{array}{l}\text { IUCN Red List Criteria } \\
\text { (EU 28) }\end{array}$ & $\begin{array}{l}\text { Endemic } \\
\text { to Europe? }\end{array}$ & $\begin{array}{l}\text { Endemic } \\
\text { to EU 28? }\end{array}$ \\
\hline Isoëtes creussensis & LC & & LC & & Yes & No \\
\hline Isoëtes delilei & NT & & NT & & No & No \\
\hline Isoëtes durieui & LC & & LC & & No & No \\
\hline Isoëtes echinospora & LC & & LC & & No & No \\
\hline Isoëtes fluitans & EN & B2ab(iii,iv,v) & $\mathrm{EN}$ & B2ab(iii,iv,v) & Yes & Yes \\
\hline Isoëtes gymnocarpa & $\mathrm{DD}$ & & $\mathrm{DD}$ & & No & No \\
\hline Isoëtes haussknechtii & EN & B2ab(iii) & EN & B2ab(iii) & Yes & Yes \\
\hline Isoëtes heldreichii & $\mathrm{CR}(\mathrm{PE})$ & $\mathrm{D}$ & $\mathrm{CR}(\mathrm{PE})$ & $\mathrm{D}$ & Yes & Yes \\
\hline Isoëtes histrix & $\mathrm{LC}$ & & LC & & No & No \\
\hline Isoëtes iapygia & $\mathrm{VU}$ & Blab(iii)+2ab(iii) & $\mathrm{VU}$ & Blab(iii)+2ab(iii) & Yes & Yes \\
\hline Isoëtes lacustris & LC & & LC & & No & No \\
\hline Isoëtes longissima & NT & & NT & & No & No \\
\hline Isoëtes malinverniana & $\mathrm{CR}$ & $\mathrm{A} 2 \mathrm{c}$ & $\mathrm{CR}$ & $\mathrm{A} 2 \mathrm{c}$ & Yes & Yes \\
\hline Isoëtes phrygia & NT & & NT & & No & No \\
\hline Isoëtes sabatina & CR & B1ab(iii)+2ab(iii) & $\mathrm{CR}$ & B1ab(iii) $+2 \mathrm{ab}(\mathrm{iii})$ & Yes & Yes \\
\hline Isoëtes tenuissima & EN & $\begin{array}{l}\text { Blab(i,ii,iiii,iv,v) } \\
+2 \mathrm{ab}(\mathrm{i}, \mathrm{ii}, \mathrm{iii}, \mathrm{iv}, \mathrm{v})\end{array}$ & EN & $\begin{array}{l}\text { B1ab(i,ii,iiii,iv,v) } \\
+2 a b(\mathrm{i}, \mathrm{ii}, \mathrm{iii}, \mathrm{iv}, \mathrm{v})\end{array}$ & Yes & Yes \\
\hline Isoëtes tiguliana & LC & & LC & & Yes & Yes \\
\hline Isoëtes todaroana & CR & Blab(iii,v)+2ab(iii,v) & CR & Blab(iii,v)+2ab(iii,v) & Yes & Yes \\
\hline \multicolumn{7}{|l|}{ Lycopodiaceae } \\
\hline Huperzia dentata & LC & & LC & & Yes & Yes \\
\hline Huperzia selago & LC & & LC & & No & No \\
\hline Huperzia suberecta & NT & & NT & & Yes & Yes \\
\hline Lycopodiella cernua & LC & & LC & & No & No \\
\hline Lycopodiella inundata & LC & & LC & & No & No \\
\hline Lycopodium alpinum & LC & & $\mathrm{LC}$ & & No & No \\
\hline Lycopodium annotinum & LC & & LC & & No & No \\
\hline Lycopodium clavatum & LC & & LC & & No & No \\
\hline Lycopodium complanatum & LC & & LC & & No & No \\
\hline Lycopodium issleri & NT & & NT & & No & No \\
\hline Lycopodium madeirense & $\mathrm{VU}$ & C2a(i) & $\mathrm{VU}$ & C2a(i) & Yes & Yes \\
\hline Lycopodium oellgaardii & NT & & NT & & No & No \\
\hline Lycopodium tristachyum & NT & & NT & & No & No \\
\hline Lycopodium zeilleri & NT & & NT & & No & No \\
\hline \multicolumn{7}{|l|}{ Marsileaceae } \\
\hline Marsilea aegyptiaca & NT & & $\mathrm{NE}$ & & No & No \\
\hline Marsilea batardae & EN & B2ab(ii,iii,iv,v) & EN & B2ab(ii,iii,iv,v) & Yes & Yes \\
\hline Marsilea quadrifolia & $\mathrm{VU}$ & A2ce & $\mathrm{VU}$ & A2ce & No & No \\
\hline Marsilea strigosa & $\mathrm{VU}$ & A2c; B2ab(iii,v) & $\mathrm{VU}$ & A2c; B2ab(iii,v) & No & No \\
\hline Pilularia globulifera & LC & & LC & & Yes & No \\
\hline Pilularia minuta & EN & B2ab(i,ii,iii,iv,v)c(iv) & EN & B2ab(i,ii,iii,iv,v)c(iv) & No & No \\
\hline \multicolumn{7}{|l|}{ Ophioglossaceae } \\
\hline Botrychium boreale & $\mathrm{LC}$ & & NT & & No & No \\
\hline Botrychium lanceolatum & $\mathrm{vU}$ & $\mathrm{A} 2 \mathrm{c}$ & $\mathrm{VU}$ & $\mathrm{A} 2 \mathrm{c}$ & No & No \\
\hline Botrychium lunaria & LC & & LC & & No & No \\
\hline Botrychium matricariifolium & NT & & NT & & No & No \\
\hline
\end{tabular}




\begin{tabular}{|c|c|c|c|c|c|c|}
\hline Taxonomy & $\begin{array}{l}\text { IUCN Red } \\
\text { List Category } \\
\text { (Europe) }\end{array}$ & $\begin{array}{l}\text { IUCN Red List Criteria } \\
\text { (Europe) }\end{array}$ & $\begin{array}{l}\text { IUCN Red } \\
\text { List Category } \\
\text { (EU 28) }\end{array}$ & $\begin{array}{l}\text { IUCN Red List Criteria } \\
\text { (EU 28) }\end{array}$ & $\begin{array}{l}\text { Endemic } \\
\text { to Europe? }\end{array}$ & $\begin{array}{l}\text { Endemic } \\
\text { to EU 28? }\end{array}$ \\
\hline Botrychium multifidum & $\mathrm{LC}$ & & NT & & No & No \\
\hline Botrychium simplex & EN & $\mathrm{A} 2 \mathrm{c}$ & EN & $\mathrm{A} 2 \mathrm{c} ; \mathrm{B} 2 \mathrm{~b}(\mathrm{v}) \mathrm{c}(\mathrm{iv})$ & No & No \\
\hline Botrychium virginianum & $\mathrm{VU}$ & B2ab(ii,iiii,iv,v) & $\mathrm{VU}$ & B2ab(ii,iii,iv,v) & No & No \\
\hline Ophioglossum azoricum & LC & & LC & & No & No \\
\hline Ophioglossum lusitanicum & LC & & LC & & No & No \\
\hline Ophioglossum polyphyllum & $\mathrm{DD}$ & & $\mathrm{DD}$ & & No & No \\
\hline Ophioglossum vulgatum & LC & & LC & & No & No \\
\hline \multicolumn{7}{|l|}{ Osmundaceae } \\
\hline Osmunda regalis & LC & & LC & & No & No \\
\hline \multicolumn{7}{|l|}{ Polypodiaceae } \\
\hline Arachniodes webbiana & $\mathrm{VU}$ & D1 & $\mathrm{VU}$ & & Yes & Yes \\
\hline Davallia canariensis & LC & & LC & & No & No \\
\hline Dryopteris aemula & LC & & LC & & No & No \\
\hline Dryopteris affinis & LC & & LC & & No & No \\
\hline Dryopteris aitoniana & LC & & LC & & Yes & Yes \\
\hline Dryopteris ardechensis & $\mathrm{VU}$ & D1 & $\mathrm{VU}$ & D1 & Yes & Yes \\
\hline Dryopteris borreri & LC & & LC & & No & No \\
\hline Dryopteris cambrensis & LC & & LC & & No & No \\
\hline Dryopteris carthusiana & LC & & LC & & No & No \\
\hline Dryopteris caucasica & $\mathrm{DD}$ & & $\mathrm{DD}$ & & No & No \\
\hline Dryopteris corleyi & LC & & LC & & Yes & Yes \\
\hline Dryopteris crispifolia & LC & & LC & & Yes & Yes \\
\hline Dryopteris cristata & LC & & LC & & No & No \\
\hline Dryopteris dilatata & LC & & LC & & No & No \\
\hline Dryopteris expansa & LC & & LC & & No & No \\
\hline Dryopteris filix-mas & LC & & LC & & No & No \\
\hline Dryopteris fragrans & LC & & LC & & No & No \\
\hline Dryopteris guanchica & LC & & LC & & Yes & Yes \\
\hline Dryopteris intermedia & LC & & LC & & No & No \\
\hline Dryopteris lacunosa & LC & & LC & & Yes & Yes \\
\hline Dryopteris mindshelkensis & LC & & LC & & No & No \\
\hline Dryopteris oligodonta & LC & & LC & & Yes & Yes \\
\hline Dryopteris oreades & LC & & $\mathrm{LC}$ & & No & No \\
\hline Dryopteris pallida & LC & & LC & & No & No \\
\hline Dryopteris pseudodisjuncta & $\mathrm{DD}$ & & $\mathrm{DD}$ & & Yes & No \\
\hline Dryopteris remota & LC & & LC & & No & No \\
\hline Dryopteris schorapanensis & $\mathrm{DD}$ & & $\mathrm{DD}$ & & No & No \\
\hline Dryopteris tyrrhena & NT & & NT & & Yes & Yes \\
\hline Dryopteris villarii & LC & & LC & & No & No \\
\hline $\begin{array}{l}\text { Elaphoglossum } \\
\text { semicylindricum }\end{array}$ & EN & B2ab(iii,iv,v) & EN & B2ab(iii,iv,v) & Yes & Yes \\
\hline Grammitis azorica & $\mathrm{CR}$ & B2ab(iii,v); C2a(i) & $\mathrm{CR}$ & B2ab(iii,v); C2a(i) & Yes & Yes \\
\hline Grammitis jungermannioides & $\mathrm{CR}$ & $\mathrm{C} 2 \mathrm{a}(\mathrm{i})$ & $\mathrm{CR}$ & $\mathrm{C} 2 \mathrm{a}(\mathrm{i})$ & No & No \\
\hline Grammitis quaerenda & $\mathrm{RE}$ & & $\mathrm{RE}$ & & No & No \\
\hline Polypodium cambricum & LC & & LC & & No & No \\
\hline Polypodium interjectum & LC & & LC & & No & No \\
\hline
\end{tabular}




\begin{tabular}{|c|c|c|c|c|c|c|}
\hline Taxonomy & $\begin{array}{l}\text { IUCN Red } \\
\text { List Category } \\
\text { (Europe) }\end{array}$ & $\begin{array}{l}\text { IUCN Red List Criteria } \\
\text { (Europe) }\end{array}$ & $\begin{array}{l}\text { IUCN Red } \\
\text { List Category } \\
\text { (EU 28) }\end{array}$ & $\begin{array}{l}\text { IUCN Red List Criteria } \\
\text { (EU 28) }\end{array}$ & $\begin{array}{l}\text { Endemic } \\
\text { to Europe? }\end{array}$ & $\begin{array}{l}\text { Endemic } \\
\text { to EU 28? }\end{array}$ \\
\hline Polypodium vulgare & LC & & LC & & No & No \\
\hline Polystichum aculeatum & LC & & LC & & No & No \\
\hline Polystichum braunii & LC & & $\mathrm{VU}$ & $\mathrm{B} 2 \mathrm{ab}(\mathrm{v}) ; \mathrm{C} 2 \mathrm{a}(\mathrm{i})$ & No & No \\
\hline Polystichum drepanum & $\mathrm{CR}$ & $\mathrm{D}$ & $\mathrm{CR}$ & $\mathrm{D}$ & Yes & Yes \\
\hline Polystichum falcinellum & NT & & NT & & Yes & Yes \\
\hline Polystichum lonchitis & LC & & LC & & No & No \\
\hline Polystichum setiferum & LC & & LC & & No & No \\
\hline \multicolumn{7}{|l|}{ Psilotaceae } \\
\hline Psilotum nudum & CR & B1ab(iii,v)+2ab(iii,v) & $\mathrm{CR}$ & B1ab(iii,v)+2ab(iii,v) & No & No \\
\hline \multicolumn{7}{|l|}{ Pteridaceae } \\
\hline Adiantum capillus-veneris & LC & & LC & & No & No \\
\hline Adiantum reniforme & LC & & LC & & No & No \\
\hline Allosorus acrosticus & LC & & LC & & No & No \\
\hline Allosorus fragilis & LC & & LC & & Yes & Yes \\
\hline Allosorus guanchicus & LC & & LC & & No & No \\
\hline Allosorus hispanicus & LC & & LC & & No & No \\
\hline Allosorus persicus & LC & & LC & & No & No \\
\hline Allosorus pteridioides & LC & & LC & & No & No \\
\hline Allosorus tinaei & LC & & LC & & No & No \\
\hline Anogramma leptophylla & LC & & LC & & No & No \\
\hline Cosentinia vellea & LC & & LC & & No & No \\
\hline Cryptogramma crispa & LC & & LC & & No & No \\
\hline Cryptogramma stelleri & LC & & $\mathrm{NE}$ & & No & No \\
\hline Paragymnopteris marantae & NT & & NT & & No & No \\
\hline Pellaea calomelanos & EN & B1ab(iii,v)+2ab(iii,v) & EN & B1ab(iii,v)+2ab(iii,v) & No & No \\
\hline Pteris cretica & LC & & LC & & No & No \\
\hline Pteris dentata & $\mathrm{DD}$ & & $\mathrm{DD}$ & & No & No \\
\hline Pteris incompleta & NT & & NT & & Yes & Yes \\
\hline Pteris vittata & LC & & LC & & No & No \\
\hline \multicolumn{7}{|l|}{ Salviniaceae } \\
\hline Salvinia natans & NT & & NT & & No & No \\
\hline \multicolumn{7}{|l|}{ Selaginellaceae } \\
\hline Selaginella denticulata & $\mathrm{LC}$ & & LC & & No & No \\
\hline Selaginella helvetica & LC & & LC & & No & No \\
\hline Selaginella kraussiana & LC & & LC & & No & No \\
\hline Selaginella selaginoides & LC & & LC & & No & No \\
\hline
\end{tabular}




\section{Appendix 2. Example of species summary and distribution map}

The Red List assessment below of Asplenium jahandiezii provides an example of the information that has been compiled for all the European lycopod and fern species, including a distribution map. You can search for and download all the assessments and distribution maps from the European Red List website and data portal available online at http://ec.europa.eu/environment/nature/conservation/ species/redlist/ and http://www.iucnredlist.org/ initiatives/europe.

\section{Asplenium jahandiezii - (Litard.) Rouy}

PLANTAE - TRACHEOPHYTA - POLYPODIOPSIDA - POLYPODIALES - ASPLENIACEAE - Asplenium - jahandiezii

Common Names: Verdon Spleenwort (English), Doradille de Jahandiez (French), Dordadille du Verdon (French) Synonyms: Asplenium fontanum (L.) Bernh. ssp. jahandiezii Litard.

Red List Assessment

\section{Assessment Information}

Date of Assessment: 2016-05-26

\begin{tabular}{|l|l|l|l|l|}
\hline Reviewed? & Date of Review: & Status: & Reasons for Rejection: & Improvements Needed: \\
\hline true & $2017-03-21$ & Passed & - & - \\
\hline
\end{tabular}

Assessor(s): Christenhusz, M., Bento Elias, R., Dyer, R., Ivanenko, Y., Rouhan, G., Rumsey, F. \& Väre, H.

Reviewer(s): García, M. \& Troia, A.

Contributor(s): Juillet, N.

Regions: Mediterranean, Global \& Europe

\section{Assessment Rationale}

Asplenium jahandiezii has an extent of occurrence (EOO) less than $900 \mathrm{~km}^{2}$, an area of occupancy (AOO) of 20$30 \mathrm{~km}^{2}$, and it is present in eight locations. It is therefore assessed as Near Threatened as it is close to qualifying as threatened under criteria B and D2. The subpopulations appears to be stable and its cliff habitat currently is well protected, but there are potential threats from mountaineering, changes in hydrological regime and road infrastructure that could rapidly drive the taxon into a threatened category if these threats begin to take effect.

\section{Reasons for Change}

No change: Same category and criteria 


\title{
Distribution
}

\section{Geographic Range}

Asplenium jahandiezii is endemic to the department of Var (southeastern France), where it is only found in the Gorges du Verdon (Commission of the European Communities 2009). Its extent of occurrence (EOO) is no more than $830 \mathrm{~km}^{2}$ and its area of occupancy (AOO) is between $20-30 \mathrm{~km}^{2}$.

\section{Area of Occupancy (AOO)}

\begin{tabular}{|l|l|}
\hline Estimated area of occupancy (AOO) - in km2 & Justification \\
\hline $20-30$ & -
\end{tabular}

\section{Extent of Occurrence (EOO)}

\begin{tabular}{|l|l|l|}
\hline $\begin{array}{l}\text { Estimated extent of } \\
\text { occurrence (EOO)- } \text { in } \mathbf{k m}^{2}\end{array}$ & $\begin{array}{l}\text { EOO estimate calculated from } \\
\text { Minimum Convex Polygon }\end{array}$ & Justification \\
\hline $47-830$ & true & $\begin{array}{l}\text { Submitted EOO was noted as } 830 \mathrm{~km}^{2} \text {, but the EOO } \\
\text { calculator on the distribution map calculates EOO as } \\
47 \mathrm{~km}^{2} .\end{array}$ \\
\hline
\end{tabular}

\section{Locations Information}

\author{
Number of Locations Justification \\ 8
}

\section{Elevation / Depth / Depth Zones}

Elevation Lower Limit (in metres above sea level): 600

Elevation Upper Limit (in metres above sea level): 800

\section{Map Status}

\begin{tabular}{|l|l|l|l|l|l|}
\hline $\begin{array}{l}\text { Map } \\
\text { Status }\end{array}$ & $\begin{array}{l}\text { How the map was created, including } \\
\text { data sources/methods used: }\end{array}$ & $\begin{array}{l}\text { Data } \\
\text { Sensitive? }\end{array}$ & Justification & $\begin{array}{l}\text { Geographic range } \\
\text { this applies to: }\end{array}$ & $\begin{array}{l}\text { Date restriction } \\
\text { imposed: }\end{array}$ \\
\hline Done & - & - & - & - & - \\
\hline
\end{tabular}

\section{Biogeographic Realms}

Biogeographic Realm: Palearctic

\section{Occurrence}

\section{Countries of Occurrence}

\begin{tabular}{|l|l|l|l|l|}
\hline Country & Presence & Origin & Formerly Bred & Seasonality \\
\hline France & Extant & Native & - & Resident \\
\hline France $>$ France (mainland) & Extant & Native & - & Resident \\
\hline
\end{tabular}

\section{Population}

This plant is present at eight locations with a total of over 100,000 individuals estimated. The population trend is apparently stable and its habitat is well protected and stable. 


\section{Population Information}

Current Population Trend: Stable

Number of mature individuals (=population size): 100000

\begin{tabular}{|l|l|}
\hline Severely fragmented? & Justification \\
\hline No & - \\
\hline
\end{tabular}

\begin{tabular}{|l|l|l|}
\hline Continuing decline in mature individuals? & Qualifier & Justification \\
\hline No & - & - \\
\hline
\end{tabular}

\section{Habitats and Ecology}

This species grows in crevices of large calcareous rocks, on overhangs of limestone cliffs (Tutin et al. 1964, Frey et al. 2006), and in shady spots in deep gorges (Prelli 2001). Its elevation limits are 600-800 m.

\section{IUCN Habitats Classification Scheme}

\begin{tabular}{|l|l|l|l|}
\hline Habitat & Season & Suitability & Major Importance? \\
\hline 6. Rocky areas (eg. inland cliffs, mountain peaks) & resident & Suitable & Yes \\
\hline $\begin{array}{l}\text { 7.1. Caves and Subterranean Habitats (non-aquatic) -> } \\
\text { Caves and Subterranean Habitats (non-aquatic) - Caves }\end{array}$ & resident & Suitable & Yes \\
\hline
\end{tabular}

\section{Systems}

System: Terrestrial

\section{Plant Specific}

\begin{tabular}{|l|}
\hline Plant Growth Forms \\
\hline Fern \\
\hline Forb or Herb \\
\hline
\end{tabular}

\section{Use and Trade}

\section{General Use and Trade Information}

\section{Species not utilized: true}

This species is not used.

\section{Threats}

The main described threats are mountaineering, rock climbing, and modification of hydrographic functioning. Roads and motorways also pose a threat. On the basis of these threats, eight locations are calculated. 


\section{Threats Classification Scheme}

\begin{tabular}{|l|l|l|l|l|}
\hline Threat & Timing & Scope & Severity & Impact Score \\
\hline $\begin{array}{l}\text { 4.1. Transportation \& service corridors }-> \\
\text { Roads \& railroads }\end{array}$ & Ongoing & $\begin{array}{l}\text { Minority } \\
(<50 \%)\end{array}$ & $\begin{array}{l}\text { Causing/Could } \\
\text { cause fluctuations }\end{array}$ & Low Impact: 5 \\
\hline $\begin{array}{l}\text { 6.1. Human intrusions \& disturbance }-> \\
\text { Recreational activities }\end{array}$ & Ongoing & $\begin{array}{l}\text { Minority } \\
(<50 \%)\end{array}$ & $\begin{array}{l}\text { Causing/Could } \\
\text { cause fluctuations }\end{array}$ & Low Impact: 5 \\
\hline $\begin{array}{l}\text { 7.3. Natural system modifications }-> \\
\text { Other ecosystem modifications }\end{array}$ & Ongoing & $\begin{array}{l}\text { Majority } \\
(50-90 \%)\end{array}$ & $\begin{array}{l}\text { Slow, Significant } \\
\text { Declines }\end{array}$ & $\begin{array}{l}\text { Medium } \\
\text { Impact: 6 }\end{array}$ \\
\hline
\end{tabular}

\section{Conservation}

Asplenium jahandiezii is listed on Annex II of the Habitats Directive and under Appendix I of the Convention on the Conservation of European Wildlife and Natural Habitats (Bern Convention). It is protected at the national level in France, under Annexe I (Association Tela Botanica 2000-2010). It is listed as Near Threatened under Criteria D2 (Olivier et al. 1995, Valentin et al. 2010, UICN France, FCBN and MNHN 2012). It is present in protected areas.

\section{Conservation Actions In- Place}

\begin{tabular}{|l|l|}
\hline Occur in at least one PA & Note \\
\hline Yes & Gorges du Verdon \\
\hline
\end{tabular}

\begin{tabular}{|l|l|}
\hline Included in international legislation & Note \\
\hline Yes & - \\
\hline
\end{tabular}

\section{Bibliography}

Association Tela Botanica. 2000-2010. Le reseau de la botanique francophone. Available at: http://www.tela-botanica.org/.

Commission of the European Communities. 2009. Composite Report on the Conservation Status of Habitat Types and Species as required under Article 17 of the Habitats Directive. Report from the Commission to the Council and the European Parliament. Brussels.

Frey, W., Frahm, J.-P., Fischer, E. and Lobin, W. 2006. The liverworts, mosses and ferns of Europe. Harley Books, Colchester.

IUCN. 2017. The IUCN Red List of Threatened Species. Version 2017-1. Available at: www.iucnredlist.org.

Olivier, L., Galland, J.-P., Maurin, H. and Roux, J.-P. 1995. Livre Rouge de la flore menacée de France. Tome I: espèces prioritaires. Museum National d'Histoire Naturelle, Service Patrimoine Naturel, Conservatoire Botanique National de Porquerolles, Ministère de l'Environnement, Paris.

Prelli, R. 2001. Les Fougères et Plantes Alliées de France et d'Europe Occidentale. Belin, Paris.

Tutin, T.G., Heywood, V.H., Burges, N.A., Valentine, D.H., Walters, S.M. and Webb, D.A. 1964. Flora Europaea volume 1 Lycopodiaceae to Platanaceae. Cambridge University Press, Cambridge.

UICN France, FCBN and MNHN. 2012. La Liste rouge des espèces menacées en France - Chapitre Flore vasculaire de France métropolitaine : premiers résultats pour 1000 espèces, sous-espèces et variétés.

Valentin, B., Toussaint, B. and Valet, J.M. 2010. Bilan de la conservation des taxons du tome 1 du livre rouge de la flore menacée de France. Centre régional de phytosociologie / Conservatoire botanique national de Bailleul, pour la Fédération des Conservatoires Botaniques Nationaux, Bailleul. 


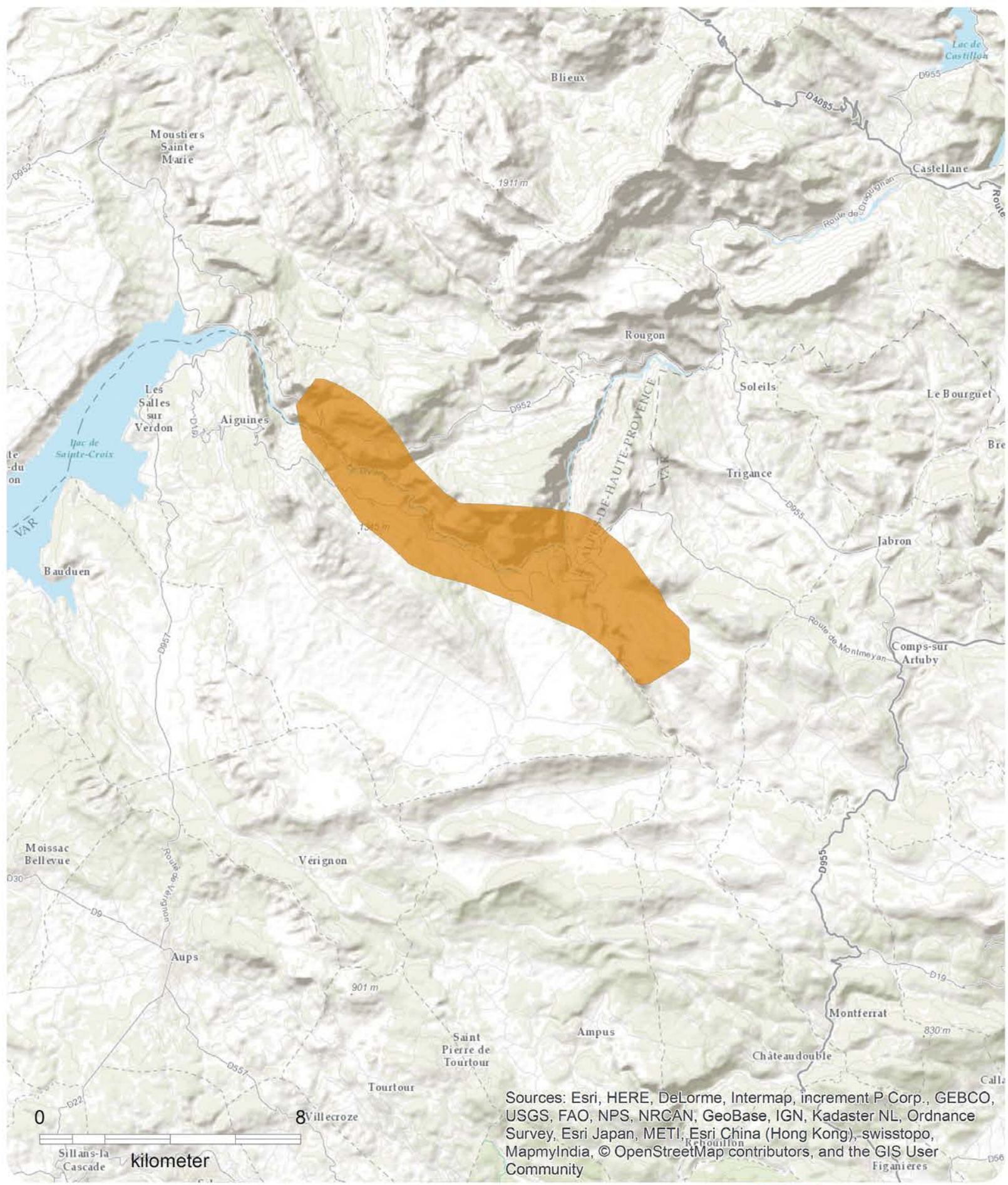

\section{Asplenium jahandiezii}

\section{Range}

Extant (resident)
Compiled by:

International Union for Conservation

of Nature (IUCN) \& Atlas Florae

Europaeae (AFE) \& GBIF
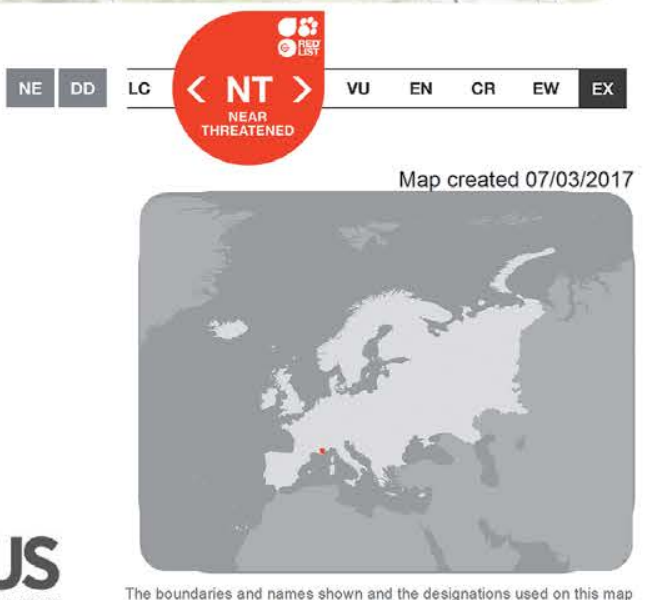


\section{IUCN Red List of Threatened Species $^{\mathrm{TM}}$ - Regional Assessments}

\section{Europe}

- The Status and Distribution of European Mammals. Compiled by Helen J. Temple and Andrew Terry, 2007

- European Red List of Reptiles. Compiled by Neil Cox and Helen J. Temple, 2009

- European Red List of Amphibians. Compiled by Helen J. Temple and Neil Cox, 2009

- European Red List of Dragonflies. Compiled by Vincent J. Kalkman, Jean-Pierre Boudot, R. Bernard, Klaus-Jurgen Conze, Geert De Knijf, Elena Dyatlova, Sonia Ferreira, Miloš Jović, Jurgen Ott, Elisa Riservato and Goran Sahlen, 2010

- European Red List of Saproxylic Beetles. Compiled by Ana Nieto and Keith Alexander, 2010

- European Red List of Butterflies. Compiled by Chris van Swaay, Sue Collins, Annabelle Cuttelod, Dirk Maes, Miguel Lopez Munguira, Martina Šašić, Josef Settele, Theo Verstrael, Rudi Verovnik, Martin Warren, Martin Wiemers and Irma Wynhoff, 2010

- European Red List of Non-marine Molluscs. Annabelle Cuttelod, Eike Neubert and Mary Seddon, 2011

- European Red List of Freshwater Fishes. Jorg Freyhof and Emma Brooks, 2011

- European Red List of Vascular Plants. Melanie Bilz, Shelagh P. Kell, Nigel Maxted and Richard V. Lansdown, 2011

- European Red List of Medicinal Plants. David J. Allen, Melanie Bilz, Rebecca Miller, Jemma Window and Anastasiya Timoshyna, 2014

- European Red List of Bees. Ana Nieto, Stuart P.M. Roberts, James Kemp, Pierre Rasmont, Michael Kuhlmann, Mariana García Criado, Jacobus C. Biesmeijer, Petr Bogusch, Holger H. Dathe, Pilar De la Rúa, Thibaut De Meulemeester, Manuel Dehon, Alexandre Dewulf, Francisco Javier Ortiz-Sánchez, Patrick Lhomme, Alain Pauly, Simon G. Potts, Christophe Praz, Marino Quaranta, Vladimir G. Radchenko, Erwin Scheuchl, Jan Smit, Jakub Straka, Michael Terzo, Bogdan Tomozii, Jemma Window and Denis Michez, 2014

- European Red List of Birds. BirdLife International, 2015.

- European Red List of Marine Fishes. Ana Nieto, Gina M. Ralph, Mia T. Comeros-Raynal, James Kemp, Mariana García Criado, David J. Allen, Nicholas K. Dulvy, Rachel H.L. Walls, Barry Russell, David Pollard, Silvia García, Matthew Craig, Bruce B. Collette, Riley Pollom, Manuel Biscoito, Ning Labbish Chao, Alvaro Abella, Pedro Afonso, Helena Álvarez, Kent E. Carpenter, Simona Clò, Robin Cook, Maria José Costa, João Delgado, Manuel Dureuil, Jim R. Ellis, Edward D. Farrell, Paul Fernandes, Ann-Britt Florin, Sonja Fordham, Sarah Fowler, Luis Gil de Sola, Juan Gil Herrera, Angela Goodpaster, Michael Harvey, Henk Heessen, Juergen Herler, Armelle Jung, Emma Karmovskaya, Çetin Keskin, Steen W. Knudsen, Stanislav Kobyliansky, Marcelo Kovačić, Julia M. Lawson, Pascal Lorance, Sophy McCully Phillips, Thomas Munroe, Kjell Nedreaas, Jørgen Nielsen, Constantinos Papaconstantinou, Beth Polidoro, Caroline M. Pollock, Adriaan D. Rijnsdorp, Catherine Sayer, Janet Scott, Fabrizio Serena, William F. Smith-Vaniz, Alen Soldo, Emilie Stump and Jeffrey T. Williams, 2015.

- European Red List of Grasshoppers, Crickets and Bush-Crickets. Axel Hochkirch, Ana Nieto, Mariana García Criado, Marta Cálix, Yoan Braud, Filippo M. Buzzetti, Dragan Chobanov, Baudewijn Odé, Juan José Presa Asensio, Luc Willemse, Thomas Zuna-Kratky, Pablo Barranco Vega, Mark Bushell, María Eulalia Clemente, José R. Correas, François Dusoulier, Sónia Ferreira, Paolo Fontana, María Dolores García, Klaus-Gerhard Heller, Ionuț Ș. Iorgu, Slobodan Ivković, Vassiliki Kati, Roy Kleukers, Anton Krištín, Michèle Lemonnier-Darcemont, Paulo Lemos, Bruno Massa, Christian Monnerat, Kelly P. Papapavlou, Florent Prunier, Taras Pushkar, Christian Roesti, Florin Rutschmann, Deniz Şirin, Josip Skejo, Gergely Szövényi, Elli Tzirkalli, Varvara Vedenina, Joan Barat Domenech, Francisco Barros, Pedro J. Cordero Tapia, Bernard Defaut, Thomas Fartmann, Stanislav Gomboc, Jorge GutiérrezRodríguez, Jaroslav Holuša, Inge Illich, Sami Karjalainen, Petr Kočárek, Olga Korsunovskaya, Anna Liana, Heriberto López, Didier Morin, Josep María Olmo-Vidal, Gellért Puskás, Vladimir Savitsky, Thomas Stalling and Josef Tumbrinck, 2016. 


\section{Other regions}

\section{Asia}

- The Status and Distribution of Freshwater Biodiversity in the Eastern Himalaya. Compiled by David Allen, Sanjay Molur and B.A. Daniel, 2010

- The Status and Distribution of Freshwater Biodiversity in the Western Ghats, India. Sanjay Molur, Kevin G. Smith, B.A. Daniel and William Darwall, 2011

- The Status and Distribution of Freshwater Biodiversity in Indo-Burma. David Allen, Kevin G. Smith, and William Darwall, 2012

\section{Africa}

- The Status and Distribution of Freshwater Biodiversity in Eastern Africa. Compiled by William R.T. Darwall, Kevin G. Smith, Thomas Lowe, Jean-Christophe Vié, 2005

- The Status and Distribution of Freshwater Biodiversity in Southern Africa. Compiled by William R.T. Darwall, Kevin G. Smith, Denis Tweddle and Paul Skelton, 2009

- The Status and Distribution of Freshwater Biodiversity in Western Africa. Compiled by Kevin Smith, Mame D. Diop and Mamadou Niane, 2009

- The Status and Distribution of Freshwater Biodiversity in Northern Africa. Compiled by Nieves Garcia, Annabelle Cuttelod and Dania Abdul Malak, 2010

- The Status and Distribution of Freshwater Biodiversity in Central Africa. Compiled by Emma G.E. Brooks, David Allen and William R.T. Darwall, 2011

- The diversity of life in African freshwaters; Underwater, under threat. An analysis of the status and distribution of freshwater species throughout mainland Africa. Edited by William Darwall, Kevin Smith, David Allen, Robert Holland, Ian Harrison and Emma Brooks, 2011

\section{Mediterranean}

- The Status and Distribution of Freshwater Fish Endemic to the Mediterranean Basin. Compiled by Kevin G. Smith and William R.T. Darwall, 2006

- The Status and Distribution of Reptiles and Amphibians of the Mediterranean Basin. Compiled by Neil Cox, Janice Chanson and Simon Stuart, 2006

- Overview of the Cartilaginous Fishes (Chondrichthyans) in the Mediterranean Sea. Compiled by Rachel D. Cavanagh and Claudine Gibson, 2007

- The Mediterranean: a biodiversity hotspot under threat. Cuttelod, A., García, N., Abdul Malak, D., Temple, H. and Katariya, V. 2008. In: J.-C. Vié, C. Hilton-Taylor and S.N. Stuart (eds). The 2008 Review of The IUCN Red List of Threatened Species. IUCN Gland, Switzerland.

- The Status and Distribution of Dragonflies of the Mediterranean Basin. Compiled by Elisa Riservato, Jean-Pierre Boudot, Sonia Ferreira, Miloš Jović, Vincent J. Kalkman, Wolfgang Schneider, Boudjema Samraoui and Annabelle Cuttelod, 2009

- The Status and Distribution of Mediterranean Mammals. Compiled by Helen J. Temple and Annabelle Cuttelod, 2009

- Overview of the Conservation Status of the Marine Fishes of the Mediterranean Sea. Compiled by Dania Abdul Malak, Suzanne R. Livingstone, David Pollard, Beth A. Polidoro, Annabelle Cuttelod, Michel Bariche, Murat Bilecenoglu, Kent E. Carpenter, Bruce B. Collette, Patrice Francour, Menachem Goren, Mohamed Hichem Kara, Enric Massutí, Costas Papaconstantinou and Leonardo Tunesi, 2011.

- Marine Mammals and Sea Turtles of the Mediterranean and Black Seas. IUCN Malaga, 2012.

- The conservation status of Sharks, Rays and Chimaeras in the Mediterranean Sea. Compiled by Nicholas K. Dulvy, David J. Allen, Gina M. Ralph and Rachel H.L. Walls, 2016.

- Overview of the conservation status of Mediterranean anthozoa. Otero, M.M., Numa, C., Bo, M., Orejas, C., Garrabou, J., Cerrano, C., Kružić, P., Antoniadou, C., Aguilar, R., Kipson, S., Linares, C., Terron-Sigler, A., Brossard, J., Kersting, D., Casado-Amezua, P., Garcia, S., Goffredo, S., Ocana, O., Caroselli, E., Maldonado, M., Bavestrello, G., CattaneoVietti, R. and Ozalp, B., 2017. 


The European Red List is a review of the status of European species according to IUCN regional Red Listing guidelines. It identifies those species that are threatened with extinction at the regional level - in order that appropriate conservation action can be taken to improve their status.

This publication summarises results for all Europe's native species of ferns and lycopods (194 species). $19.9 \%$ of species are threatened with extinction at the European level mainly due to urbanization and infrastructure, human intrusions and disturbance, pollution, and water use and management.

The European Red List was compiled by IUCN with support from the IUCN Species Survival Commission and other experts. It is a deliverable of a LIFE project co-funded by the European Commission (LIFE European Red Lists, LIFE14 PRE/BE/000001).

It is available online at http://ec.europa.eu/environment/nature/conservation/species/redlist and http://www.iucnredlist.org/initiatives/europe 